\title{
坐骨神経および三叉神経刺激による反射性 筋収縮に関する神経薬理学的研究
}

\author{
関西医科大学第二生理学教室（指導 : 安原基弘教授）
}

加藤 恭 一

（昭和62年 5 月 11 日受付）

索引用眖 : Microvibration, 侵害反射, 瞬目反射, 脳幹網様体, 中枢作用薬

\begin{abstract}
緒 专
ヒトの眼䀫部に何らかの刺激を加えた時に誘発される 反射性筋収縮については, 1896年 Overend ${ }^{1}$ が最初に報 告して以来, Levinsohn2) 3) が報告し, 1945年 Wartenberg4)がこれを眼輪筋反射（orbicularis oculi reflex）と 命名した.

一方, 生理的に存在与る身体表面の微小振動（microvibration)については Rohracher5)が最初に記載したが, 閃光刺激によって誘発される誘発眼眕 microvibration 反

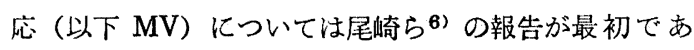
る.このような上眼䀫の反射性笳収縮反応は, 電位変 化として, あるいは加速度的変化である MV の研究と して発展し, その発現機序と臨床的意義が検討されつつ ある.
\end{abstract}

MV の基礎的検討については, 当教室の西浦7), 服部 8), 山田9 10), 山本 ${ }^{11)}{ }^{12)}$ らの報告があるが, 西浦は この反射経路について詳細な実験を行い, 光刺激による MV (photo-evoked eyelid microvibration) は, 網膜の 興鹪に始まり，その impulse は視神経から視索に至り， 外側眎状体を経由せずに脳幹部に向い，さらに動眼神経 核, 内側絽束, 顔面神経核などを経由して眼䀫部に到達 することを明らかにした。 また服部8 は，光眼輪笳反射 (PPR) には網膜の興奮に基うく early component 々脑 幹部の神経組織の activity が関与する late component が存在し,この late component のうち, MVの発現に直 接関与するのは $\mathrm{PPR}_{6}$ から $\mathrm{PPR}_{8}$ までの成分であるとし た. また山田 $9^{9} 1^{10}$ は, 聴覚誘発眼輪笳反射 (AMV) に 関するウサギでの実験において, AMV が筋弛綏薬であ る Pancuronium bromide によって著明に抑制されたこ とから，AMVはMV 同様饬原性反応であること，ま
た諸種中枢抑制薬および興奮薬に対する反応態度から， また中枢神経系の破壊および切断実験から，AMV は中 脳下部から延蹎上部の間に，その反射経路を有し，下丘 あるいはそれ以下の聴覚経路を求心路とし, MV と同様 中脳網様体の機能と密接な関連を持つことを明らかにし た. また山本 $\left.{ }^{11}{ }^{12}\right)$ は, 閃光刺激によりウサギ上眼䀫に 誘発される MV に及ぼす皮質下核（尾状核，被壳，淡 蒼球，扁桃核，海馬および視床 VL 核) の刺激および破 壊の影響について検討し, MV は知覚系のみならず錐体 外路系の機能とも, 密接な関連があるものと推定してい る. また立花 ${ }^{13)}$ は，坐骨神経刺激によって上眼䀫に誘 発される MV (SMV) およびその電位変化である眼輪筋 反射 $(\mathrm{SPR})$ を, 大脳皮質と海馬に拈ける加算誘発電位と 比較検討することにより，その経路と機能的意義を明ら かにしようと試みている.

本研究においては，ウサギを用いSMV のほかに新た 亿前脛骨笳に誘発される侵害反射 (sciatic-evoked nociceptive reflex, 以下 SNR)を記録して SMV と SNRの 関倸を比較検討すると共に，さらに三叉神経分枝に電気 刺激を加えた場合に上眼䀫に誘発される MV (trigeminal -evoked eyelid microvibration, 以下 TMV) を測定し, 同時に上眼眕の電位変化として把えた瞬目反射 (blink reflex, 以下 BR)を記録した. また，この際諸種中枢作 用薬を投与して神経薬理学的検討を行うと共に，視床核 (VPM, VPL, VA, CM など), 中脳網様体, 動眼神経 核の破壊実験を行って, TMV, BR の発現機序について 検討を行ったので報告する.

\section{実酫方法}

実験動物としては, 体重 $2 \mathrm{~kg}$ 前後のウサギを使用し， 無麻醉下にて実験を行った. まず気管切開を行い，T字 
形の気管カニューレを抻入して気道を確保した。

\section{（1）坐骨神経刺激による SMV の等出}

東大脸研型脳定位固定装置に固定したウサギの上眼䀫 を剃毛した後, 眼䀫部の微細振動を導出するために, チタン酸ジルコン酸鉛圧電素子で作られた MV 導出用 transducer（日本光電 MT-47111）を電極糊により，上 眼䀫に接着した。

坐骨神経は，一側の下肢の毛をできるだけ広く刈りと り，その外側部の皮唐を，楞筒部を中心として大腿から 下腿にかけて切開し，さらに筋肉にも切開を加えて坐骨 神経を露出させた. 坐骨神経の本幹は, 大腿のほぼ中央 で脛骨神経と腓骨神経に分かれるが，本実駼において は，下腿のできるだけ末梢部において脛骨神経を縫合系 で結紮し，その中枢端に刺激を加えた。

刺激電極としては, 直径 0.5 m銀線 2 本を, 約 $2 \mathrm{~mm}$ の間隔で並べ，その先端を鈎状に曲げたものを使用し， これを脛骨神経にかけて，電子管刺激装置（日本光電 MSE-3R) により, 1 秒 1 回の頻度で, 0.4 5.0 volt, $1 \mathrm{msec}$ の刺激を与えた. ついで transducer からの入力 を脳波計（三栄測器 $\mathrm{EG}-400$ ) で増巾させた後, データ 処理平均加算装置（日本光電 ATAC-201）に連結し， これらの電位变化を刺激装置から出されるトリガ一信号 により，50回平均加算し，得られた波形をポラロイドカ メラで撮影記録した。

分析時間は $100 \mathrm{msec}$ とし, 増巾器の時定数は 0.3 秒, high cut filter $25 \mathrm{~Hz}$ とした.

\section{（2）侵害反射性筋放漫（SNR）の等出}

上記(1)で述べた坐骨神経刺激時の SMV 導出のほか に, 同時に前脛骨筋部よりの侵害反射性筋放電を導出し た. 坐骨神経刺激と同側の前脛骨笳に，同心型針電極を 刺入し，坐骨神経刺激時に 発生する筋電図を(1)の SMV 之同様に脑波計にて増巾させた後, データ処理平均加算 装置（日本光電 ATAC-201）にて，50回平均加算し，得 られた波型をポラロイドカメラで撮影記録した.

分析時間は $100 \mathrm{msec} と し$, 増巾器の時定数は 0.05 秒とした.

なお，この際，諸種中枢作用薬として Barbiturate (Pentobarbital sodium), CDP-choline, TRH tartrate (酒石酸プロチレリン, 以下 $\mathrm{TRH}$ ), Cardiazol および Amphetamineを使用し，これらの薬物による SMV お よび SNR に対する影響を検討した。これらはいずれも 耳静脈より注入した。

（3）眼窝上神経刺激時の TMV および BR の刑出

常法により東大脳研型脳固定装置にて固定したウサギ について，まず頭頂部頭皮を切開して頭蓋骨を露出さ
せ，ついで左眼筒上部近傍の頭蓋骨に手動式ドリルに $\tau$, 直径 $5 \mathrm{~mm}$ 程度の骨窓をあけ, 眼筒上神経を露出させ るための開口部とした．脳実質への損傷に注意しなが ら，この骨窓に骨鉜子およびピンセットを用いて，てい ねいに眼窩を覆う骨を涂離していくと，三叉神経の分枝 の 1 つ眼䈑上神経の走行が観察される.この眼䈪上神経 を露出させ，これに直径 $0.5 \mathrm{~m}$ の 2 本の銀線よりなる鈎 状の電極をかけ，これを刺激電極とした。

一方，上眼倹中央に直径 $10 \mathrm{~mm}$ の円盤状血電極を電極糊 にて装着し，上眼䀫に発生せる BR を導出した。 また TMVは(1)で述べた如く, MV 導出用 transducerに 導出記録した。なお刺激は，電子管刺激装置（日本光電 MSE-3R) にて, 1 秒 1 回の頻度で, $1.0 \sim 4.0$ volt, 1 msec の刺激を与えた。

この際発生せる TMV および BR の加算誘発電位は, データ 処理平均加算装置（日本光電 ATAC-201）によ り50回平均加算し，得られた波形をポラロイド・カメラ にて撮影記録あるいは，X-Yレコーダー(GRAPHTEC WX1000-UM-101）で記録した. 分析時間は $100 \mathrm{msec}$, 增巾器の時定数は, TMV 0.3秒, BR 0.05秒とした.

なお,この際, 諸種中枢作用薬による影響も検討し た. 使用薬物は, Barbiturate (Pentobarbital sodium), CDP-choline, TRH tartrate, Cardiazol および Morphine であった.

\section{（4）中枢破壤と TMV および BR の蒴出}

脳定位固定装置に固定したウサギの頭蓋骨を露出し， 骨鋭匙で骨膜を涂離した後, bregma（冠状縫合と矢状縫 合の交叉点）と lambda（矢状縫合と人字縫合の交点） とを露出し，Sawyer らの脳図譜の水平規準面に合致す るよう lambdaを bregma より $1.5 \mathrm{~mm}$ 低くして頭部を固 定する. ついで手動式ドリルおよび骨鈷子を用いて，一 側の眼筒上部近傍の頭蓋骨に直径約 5 mmの骨空をあけ, 骨鋁子を使って目的とする破壊電極刺入部の頭蓋骨およ び脳膜を除去すると脳実質が露出する.

通電破壊電極としては, 直径 $250 \mu$ のステンレス線を カシュー叙料により絶縁し，その先端 $0.5 \mathrm{~mm}$ を剃刃で制 嶊したものを 2 本ならべ，同塗料より接着した並列型双 極針電極を作製し，これを電極支持器にて垂直に装着し て用いた。

Sawyer らの脳図譜にしたがい，視床核のVPL（後 外側腹側核 nucl. ventralis posterolateralis), VPM (後 内側腹側核 nucl. ventralis posteromedialis), VL (外 腹側核 nucl. ventralis lateralis) および VA（前腹側核 nucl. ventralis anterior) などに破壊電極を刺入し，こ れに電子管刺激装置（日本光電 MSE-3R）にて40 volt 
の直流を 30 秒間通電して電気凝固を行った後， 1 時間後 に眼窩上神経刺激による TMV および BR を導出した。 これを50回平均加算し，得られた波形をポラロイドカ メラで撮影または X-Y レコーダー(GRAPHTEC WX1000-UM-101）で記録した。分析時間は100 msec とし, 增巾器の時定数は TMV 0.3秒, BR 0.05秒とした.

脳内の破壊部位は，いずれも実験終了後脳を取り出 し，組織標本を作製して正確な位置を確認した。

\section{実䣯成较}

I．坐神経刺激による SMV と SNR に関する実 梌

\section{A. 基礎的検討}

\section{1）上眼瞼 SMV の波形と各成分の頂点潜時}

右坐骨神経に0.4 5.0 volt, 1 秒 1 回, $1 \mathrm{msec}$ の電 気刺激を与え，右上眼䀫に誘発される SMV を記録し た. 第 1 図はSMV の代表的な波形を示す.これは, 電 気刺激によって誘発される微細振動を加速度变化として とらえ, digital computer を介して，50回平均加算した

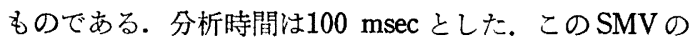
波形は，3つの component からなり，私たちはその出 現順に $\mathrm{SMV}_{1}, \mathrm{SMV}_{2}$ および $\mathrm{SMV}_{3}$ と命名した ${ }^{13}$.

ウサギ20匹における SMV 各 component の頂点潜時 の分布およびその平均值（mean 土S.D.）注第 1 表お よび第 2 図に示した.

$\mathrm{SMV}_{1}$ の頂点潜時の分布巾は $27 \sim 62 \mathrm{msec}$ で, 平均値

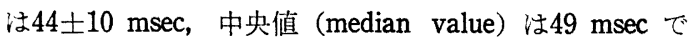
あった. $\mathrm{SMV}_{2}$ の頂点潜時は 44 から $81 \mathrm{msec}$ まで分布

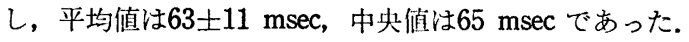
また $\mathrm{SMV}_{3}$ では，71〜97 $\mathrm{msec}$ の範囲で頂点潜時は分 布し, 平均值は84 $77 \mathrm{msec}$, 中央值は $85 \mathrm{msec}$ であっ た.

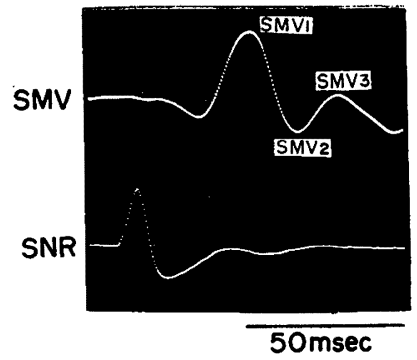

第 1 図 坐骨神経刺激により上眼䀫に誘発 された SMV と前脛骨筋に誘発 された SNR

第 1 表 SMV の各 component および SNR の頂点 潜時 $(n=20)$

\begin{tabular}{|c|c|c|}
\hline \multicolumn{2}{|c|}{ Response } & $\begin{array}{c}\text { Peak Latency } \\
\text { (msec) }\end{array}$ \\
\hline \multirow{3}{*}{ SMV } & SMV1 & $44 \pm 10$ \\
\cline { 2 - 4 } & SMV2 & $63 \pm 11$ \\
\cline { 2 - 4 } & SMV3 & $84 \pm 7$ \\
\hline \multicolumn{2}{|c|}{ SNR } & $13 \pm 5$ \\
\hline
\end{tabular}

(mean $\pm S . D$.

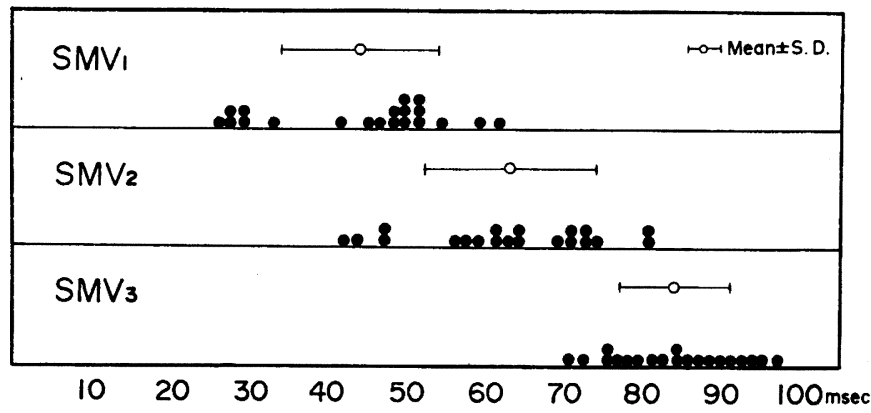

第 2 図 SMV 各 component の頂点潜時の分布 $(n=20)$ 
2）前脞骨筋に誘発される SNR の波形とその頂点潜 時

1) の実験において，坐骨神経 (脛骨神経) 刺激時 飞, 前脛骨筋に誘発される侵害反射性筋放電を記録する と，第 1 図下段に示すような波形が得られるが，私は 前記の如く, これを SNR (sciatic-evoked nociceptive reflex）と命名した，その頂点潜時の分布を第 3 図に示 したが, その平均值 (mean \pm S.D.) は, $13 \pm 5 \mathrm{msec}$, 中央値は14 msec であった。

\section{3) 刺激反復時の habituation}

1）の実験において，0.4〜5.0 volt の電気刺激を約 10 分間隔で50回平均加算を $5 \sim 6$ 回反復した場 合, SMV 各成分の頂点潜時および振巾の経時変化, 即ち habituation の現象について検討した，その成績は第 2 表およ び第 4 図に示す通りである.

まず SMV および SNR の頂点潜時については, 今回 の実験条件下では前後において有意の変化を示さなか った. しかしながら，同時に記録した SMV および SNR の振巾は, 経時的に減衰の傾向が認められた（第 3 表).

4）刺激部位の左右差による SMV および SNR の 波形

次に SMV の導出部位を右眼䀫上部に固定し，電気刺

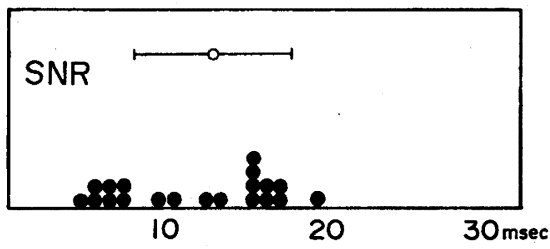

第 3 図 SNR の頂点潜時の分布 $(n=20)$
第 2 表 坐骨神経刺激反復時の SMV の各 component および SNR の頂点潜時の経時変化 $(\mathrm{n}=20)$

\begin{tabular}{|c|c|c|c|}
\hline Response & $\begin{array}{c}\text { CONTROL } \\
\text { (msec) }\end{array}$ & $\begin{array}{c}\text { After } \\
\text { (msec) }\end{array}$ & t- test \\
\hline SMV & $44 \pm 10$ & $46 \pm 10$ & n.s. \\
\hline SMV $_{2}$ & $63 \pm 11$ & $64 \pm 9$ & n.s. \\
\hline SMV $_{3}$ & $84 \pm 7$ & $86 \pm 7$ & n.s. \\
\hline SNR & $13 \pm 5$ & $12 \pm 5$ & n.s. \\
\hline
\end{tabular}

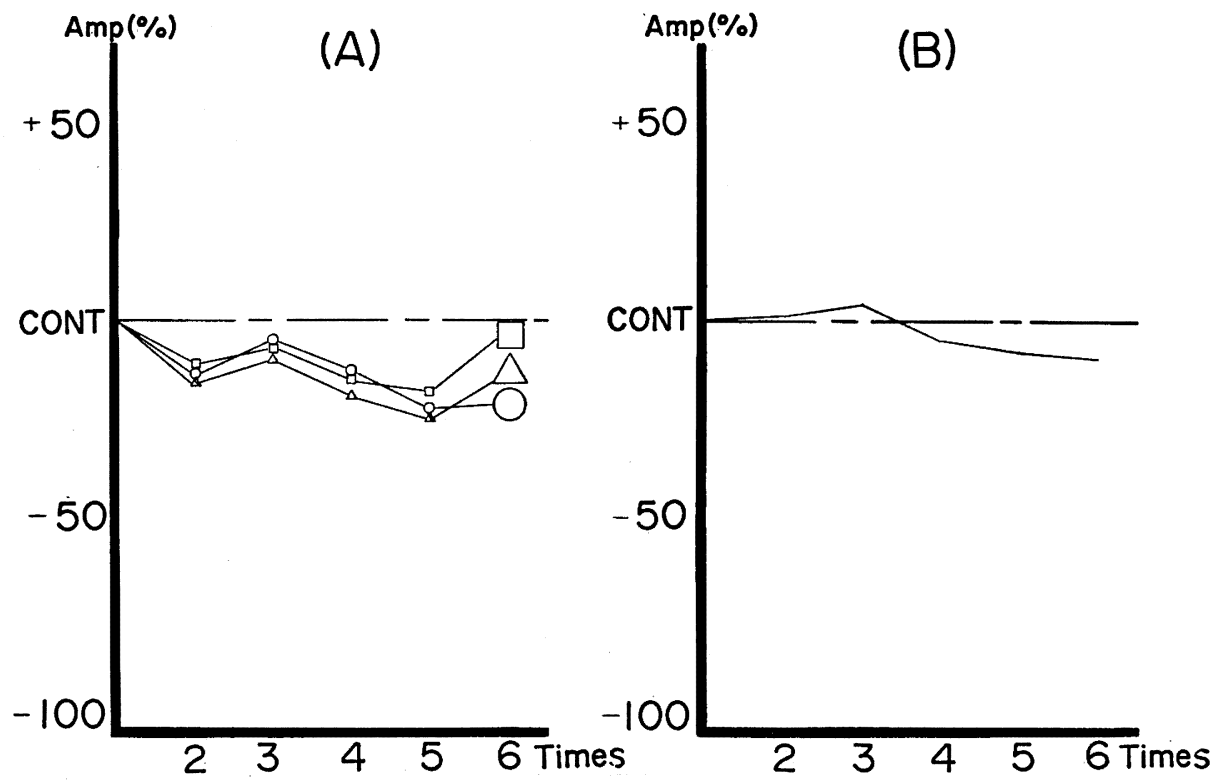

第 4 図 坐骨神経刺激反復による SMV (A) の各 component および SNR (B) の振巾の habituation 注: 丸印は $\mathrm{SMV}_{1}$, 三角印は $\mathrm{SMV}_{2}$, 四角印は $\mathrm{SMV}_{3}$ をあらわす. 
第 3 素 坐骨神経刺激反復時の SMV の各 component および SNRの 振巾の経時变化 $(n=20)$

\begin{tabular}{|c|c|c|c|c|c|c|}
\hline Response & $\begin{array}{c}\text { CONT } \\
(\mathrm{msec})\end{array}$ & 2nd & 3rd & 4 th & 5th & 6 th \\
\hline SMV $_{1}$ & $100^{*}$ & $87 \pm 33$ & $95 \pm 42$ & $85 \pm 40$ & $77 \pm 39$ & $79 \pm 51$ \\
\hline SMV $_{2}$ & 100 & $85 \pm 26$ & $90 \pm 31$ & $81 \pm 40$ & $77 \pm 40$ & $87 \pm 56$ \\
\hline SMV3 & 100 & $89 \pm 41$ & $93 \pm 41$ & $85 \pm 47$ & $82 \pm 47$ & $98 \pm 74$ \\
\hline SNR & 100 & $101 \pm 37$ & $104 \pm 49$ & $95 \pm 57$ & $92 \pm 54$ & $90 \pm 67$ \\
\hline
\end{tabular}

* control（初回）を100として, その後の増減を\%で表わした.

第 4 表 坐骨神経刺激部位の左右差による SMV の各 component およびSNR の頂点潜時 $(n=12)$

\begin{tabular}{|c|c|c|c|}
\hline Response & $\begin{array}{l}R-S c i ~ N \\
(\mathrm{msec})\end{array}$ & $\begin{array}{l}\text {-Sci N } \\
(\mathrm{msec})\end{array}$ & t-test \\
\hline SMV1 & $40 \pm 11$ & $44 \pm 11$ & n.s. \\
\hline SMV $_{2}$ & $60 \pm 11$ & $62 \pm 10$ & n.s. \\
\hline SMV $_{3}$ & $83 \pm 7$ & $80 \pm 10$ & n.s. \\
\hline SNR & $12 \pm 5$ & $12 \pm 5$ & n.s. \\
\hline
\end{tabular}

激を加える坐骨神経（前脛骨筋）を右から左にかえた時 に，その頂点潜時がどう变化するか検討した.

その結果，第 4 表に示す如く，右上眼䀫の SMV の頂点 潜時および前脛骨筋 SNR は，右下肢坐骨神経刺激時と 左下肢坐骨神経刺激時との間に有意差は認められなかっ た.

\section{5) まとめ}

以上，以後に実施する各種中枢作用薬の投与実験に先 立ち，坐骨神経刺激時に誘発される上眼䀫の SMVおよ び前脛骨筋における SNR の発現に関する基礎的事項に ついて検討した.

その結果, 坐骨神経刺激時に誘発される右上眼䀫の SMV は，3つの component からなること，その頂点潜 時は個体により若干のバラッキはあるが, 平均值 (mean 土 S.D. ) でみると $\mathrm{SMV}_{1}$ は $44 \pm 10 \mathrm{msec}, \mathrm{SMV}_{2}$ は

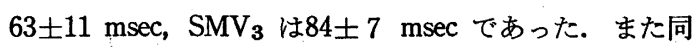
時に記録した右前脛骨筋に誘発される SNR の潜時は, $13 \pm 5 \mathrm{msec}$ であった。
ついで刺激反復時の habituation をしらべたが, SMV および SNR の頂点潜時については有意の変化を認めな いものの, その振巾は経時的に減衰傾向を示した. また 刺激部位の左右差による SMV の頂点潜時についても, 有意の変化を認めなかった。

\section{B. SMV および SNR に対する諸種中枢作用薬の影}

使用薬唷としては, Barbiturate, CDP-choline, TRH, Cardiazol および Amphetamine の5種で, 対照として 注射用蒸留水を用いた。

各薬剂は，約10分間隔で耳静脈内に投与し SMV ある いは SNR の測定は静注後 3 分に行った.

実験条件は，上記 A.の場合と同一で，1秒 1 回，0.4 〜 5. 0 volt, $1 \mathrm{msec}$ の電気刺激を加え, それによって誘 発される右上眼䀫部 SMV および右前脛骨筋 SNRを50 回平均加算した.

\section{1) Barbiturate の影䈉}

Barbiturate は，1，3，5，10および $20 \mathrm{mg} / \mathrm{kg}$ を投与 した.

第 5 図はその実験の 1 例で, 第 6 図はSMV の成績を 振巾についてまとめたものである。この図表において横 軸は投与量を表わし, 緃軸は投与後の振巾の変化を, 投 与前の百分率で，増大した場合は上方に，減少した場合 には下方にとったもので，太い線は平均值を結ぶ曲線で ある.

この四表より $\mathrm{SMV}_{1}$ と $\mathrm{SMV}_{2}$ の振巾は $1,3 \mathrm{mg} / \mathrm{kg}$ までは若干減衰傾向を示すが， $5 \mathrm{mg} / \mathrm{kg}$ で元の状態に戻 りそそれ以上 Barbiturate を増量すると，強く抑制され ることが明らかである.

$\mathrm{SMV}_{3}$ では, 3, $5,10 \mathrm{mg} / \mathrm{kg}$ までは, むしろ増大を 示し,さらに大量では抑制された。 


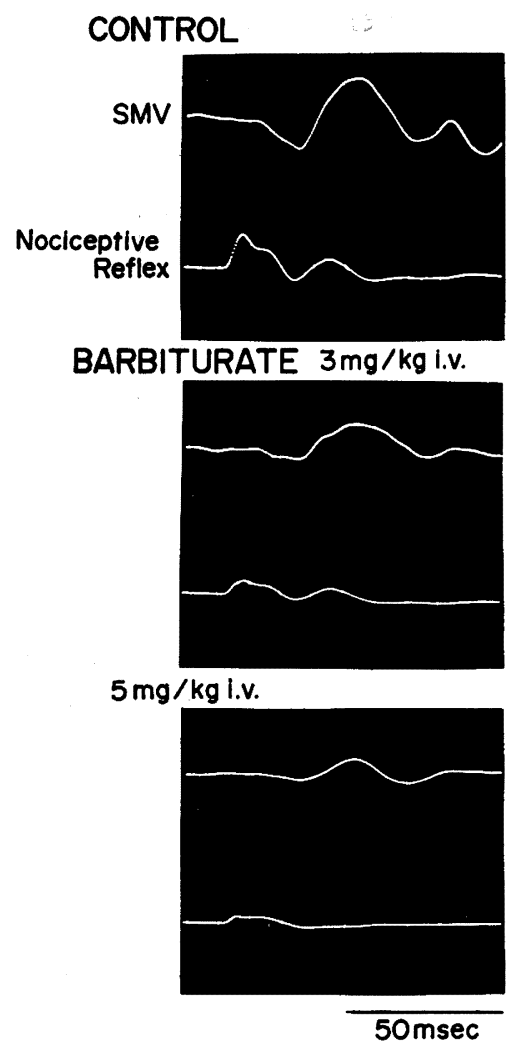

第 5 図 SMV および SNRに対する Barbiturate の影響
一方, SNR 法第 7 図に示すように Barbiturate の投 与により， $1,3 \mathrm{mg} / \mathrm{kg}$ では振巾の軽度の増大を認め, $5 \mathrm{mg} / \mathrm{kg}$ 以上で投与量に平行して抑制が強くなった。

2 ) CDP-choline の影事

次に中枢神経賦活剤である CDP-choline の影響につ

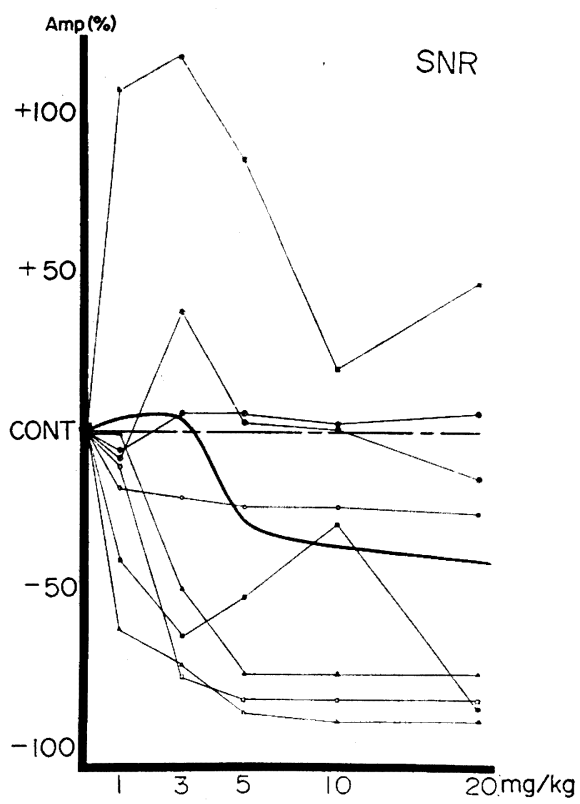

第 7 図 SNR の振巾の Barbiturate 投与による変化率

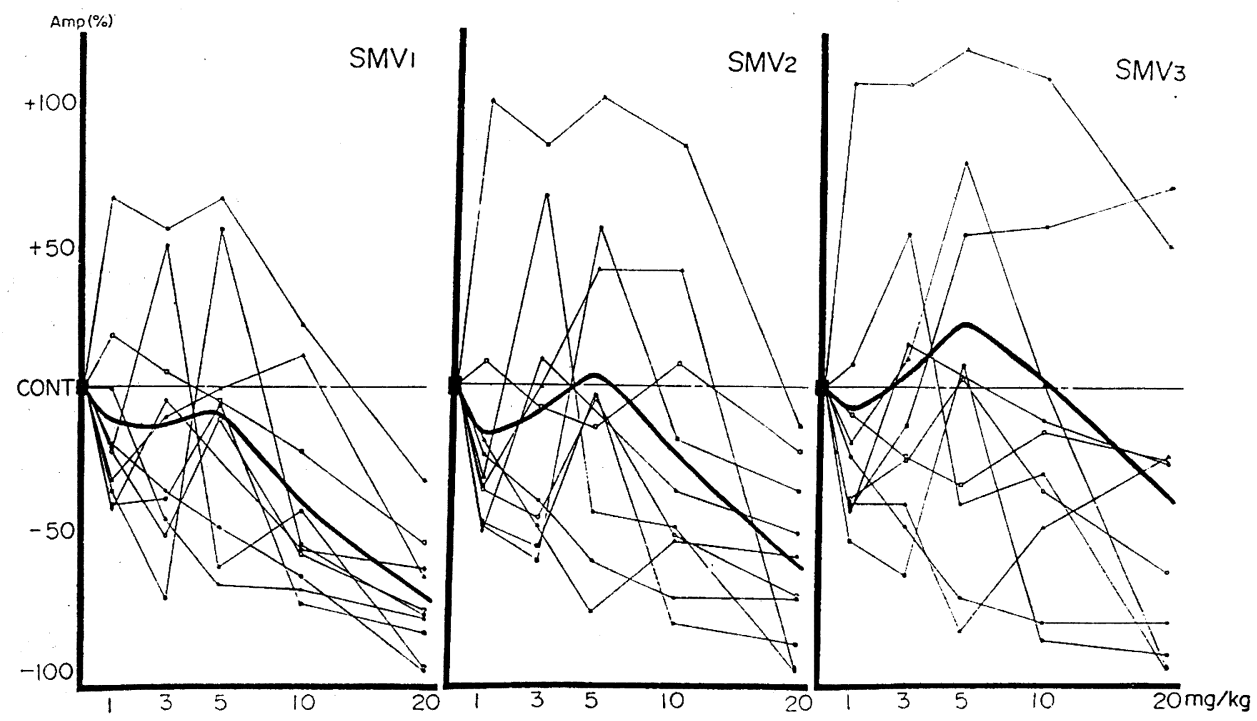

第 6 図 SMV の各 component 振巾の Barbiturate 投与による变化率 


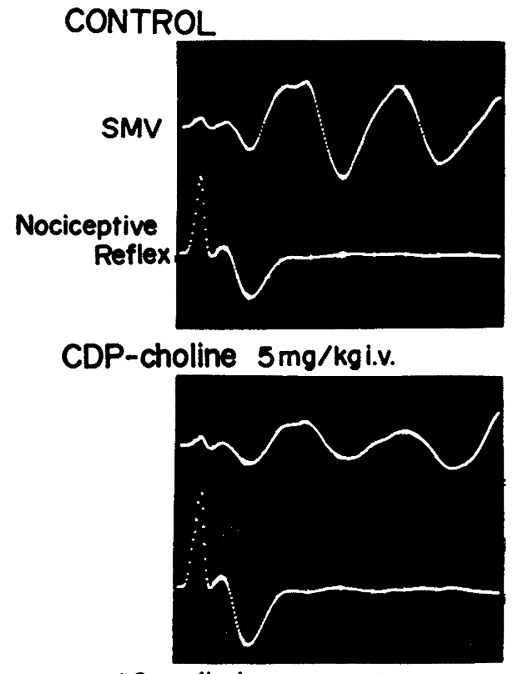

$10 \mathrm{mg} / \mathrm{kg}$ i.v.

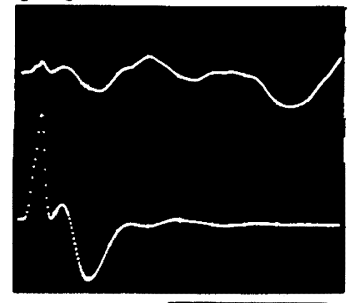

$50 \mathrm{msec}$

第 8 図 SMV および SNR に対する CDP-choline の 影響
いて検討した。

CDP-choline は， 1，3，5，10および $20 \mathrm{mg} / \mathrm{kg} の 5$ 用 量を静注した. 第 8 図にその代表例を，第 9 図にSMV の振巾の变化率を示した.

$\mathrm{SMV}_{1}$ は $5 \mathrm{mg} / \mathrm{kg}$ 以上で振巾の增大, $\mathrm{SMV}_{2}$ は軽度の

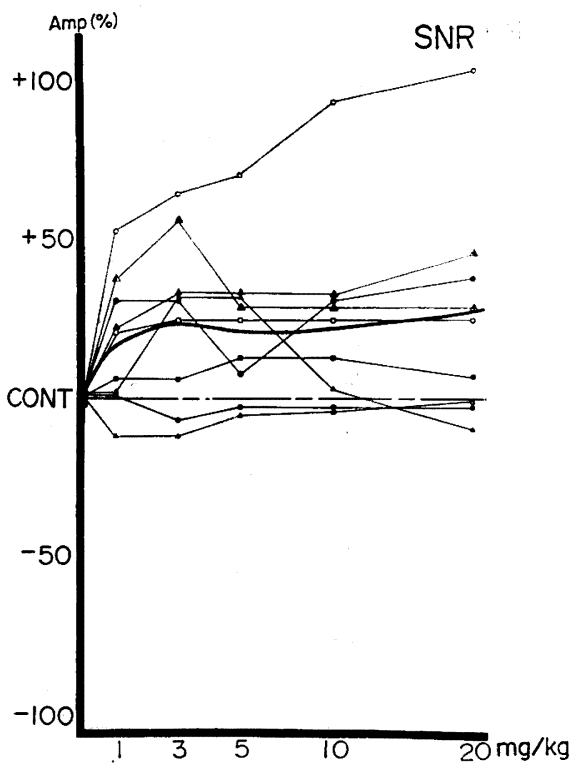

第10図 SNR の振巾の CDP-choline 投与による变化率

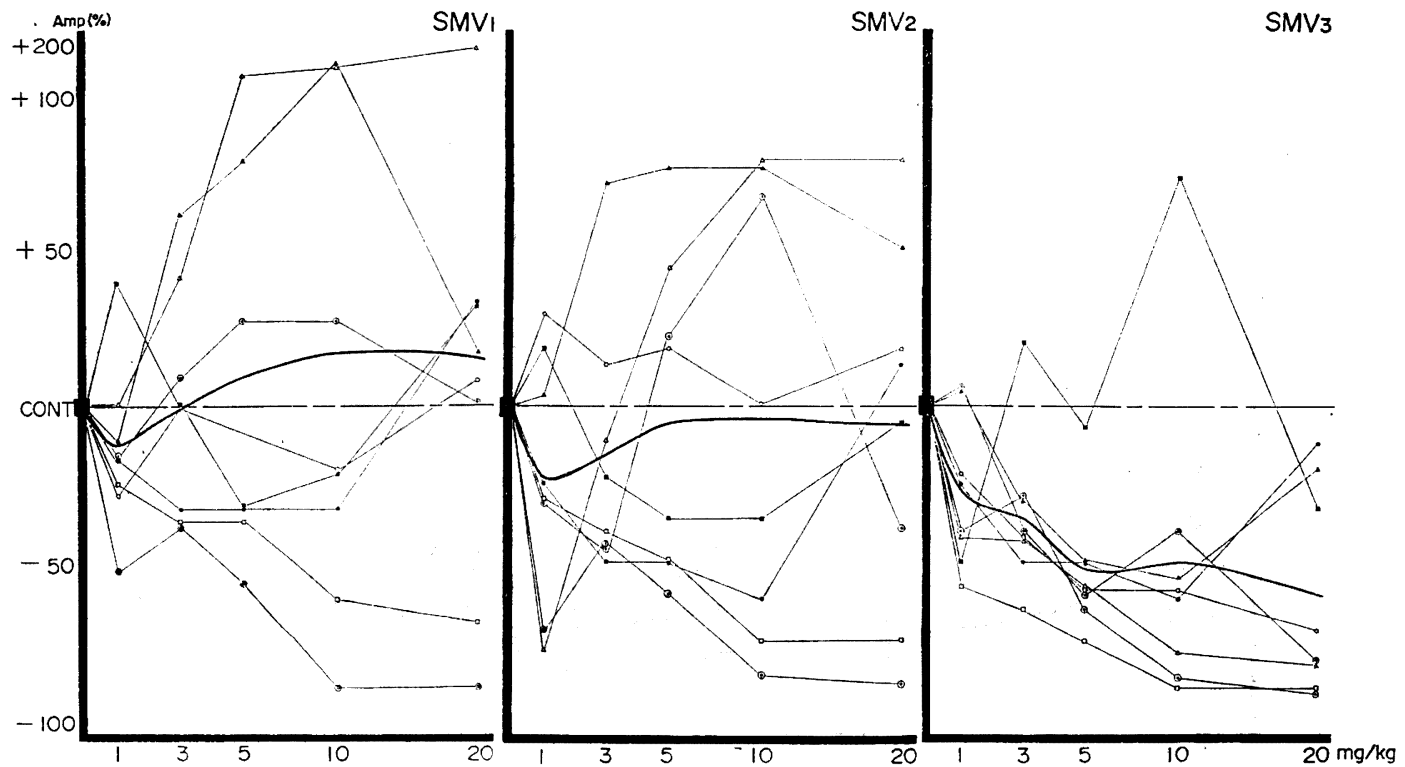

第 9 図 SMV の各 component 振巾の CDP-choline 投与による変化率 


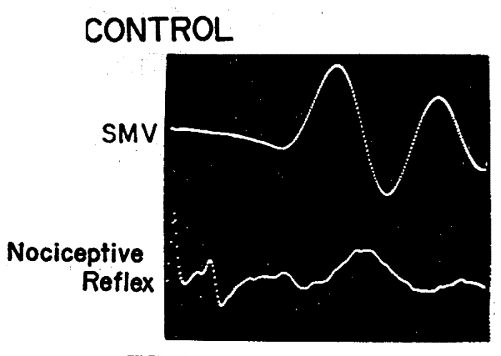

TRH $0.5 \mathrm{mg} / \mathrm{kg}$ i.v.

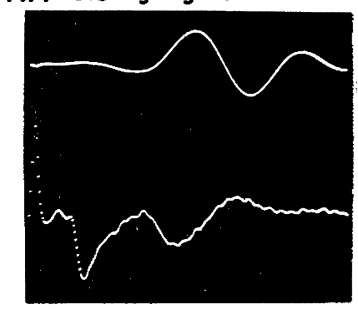

$1.0 \mathrm{mg} / \mathrm{kg}$ i.v.

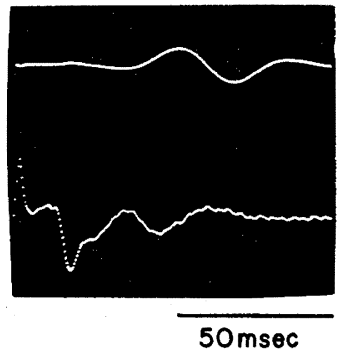

第11図 SMV および SNR に対する TRH の影響
振巾減少を示した. $\mathrm{SMV}_{3}$ は, $\mathrm{SMV}_{1}, \mathrm{SMV}_{2}$ と異な り，投与量に比例して振巾の強い抑制が観察された。

一方，第10図に示した SNR は，SMV の変化と対照 的に, 安定した振巾の増大が認められた。

\section{3) TRH の影教}

次に臨床的には中枢神経刺激薬として用いられ，

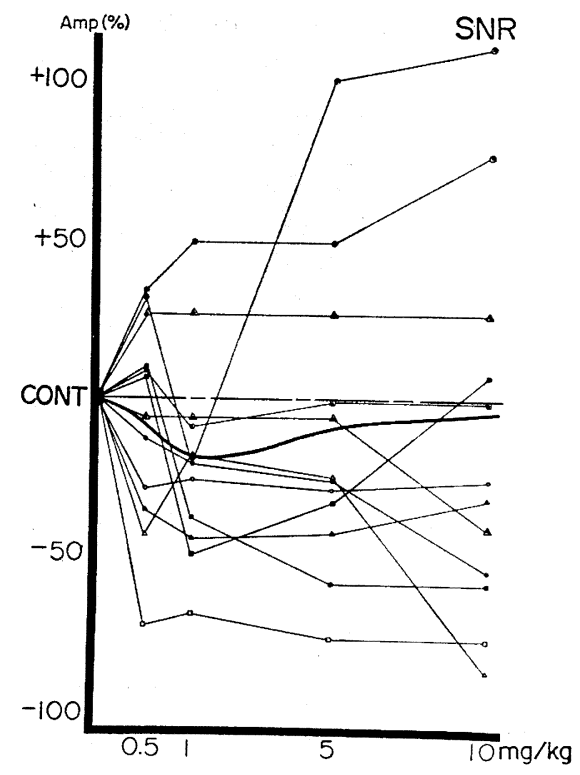

第13図 SNR の振巾の TRH 投与に上る変化率

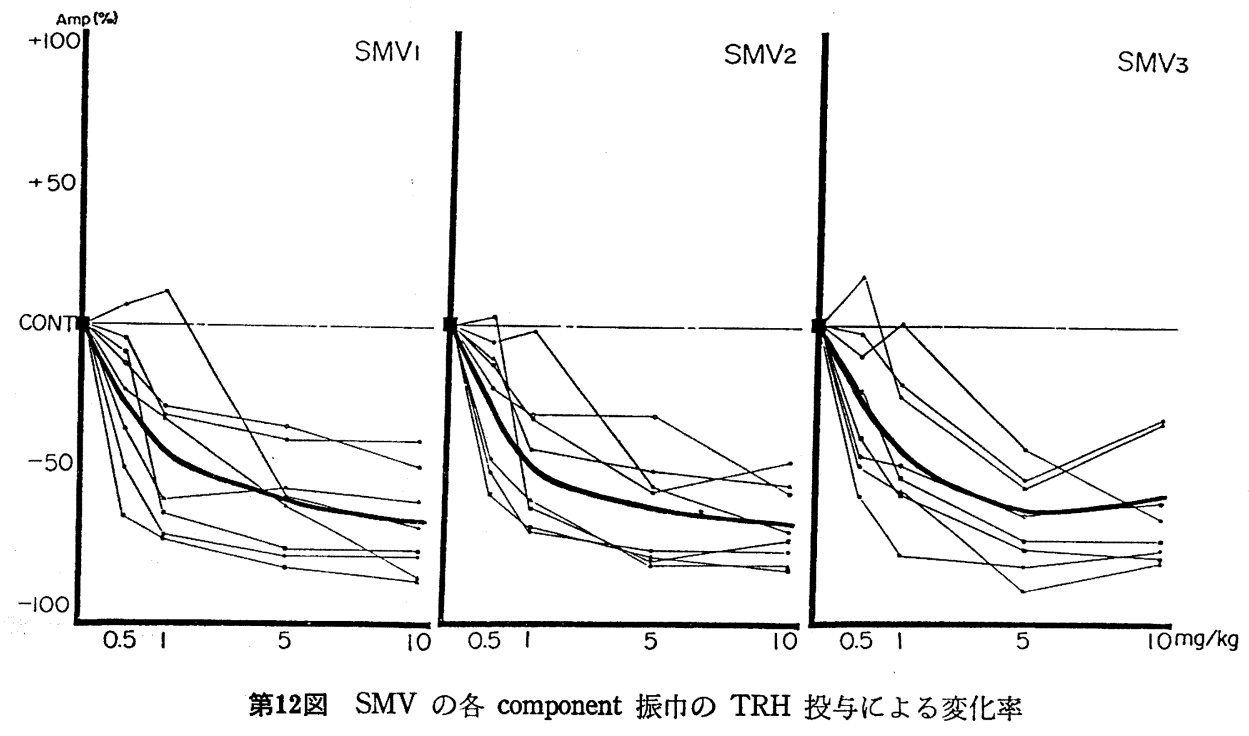




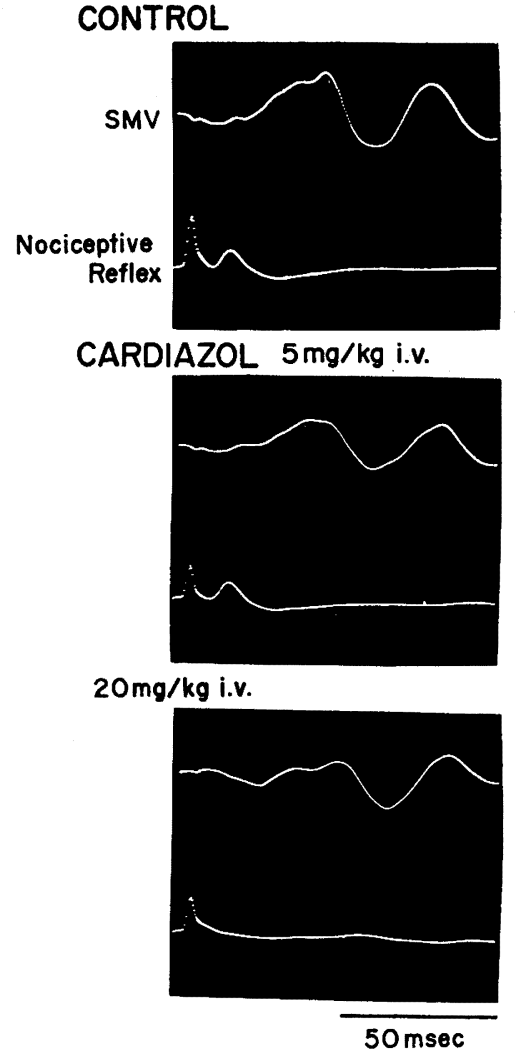

表14図 SMV および SNR に対する Cardiazol の 影響
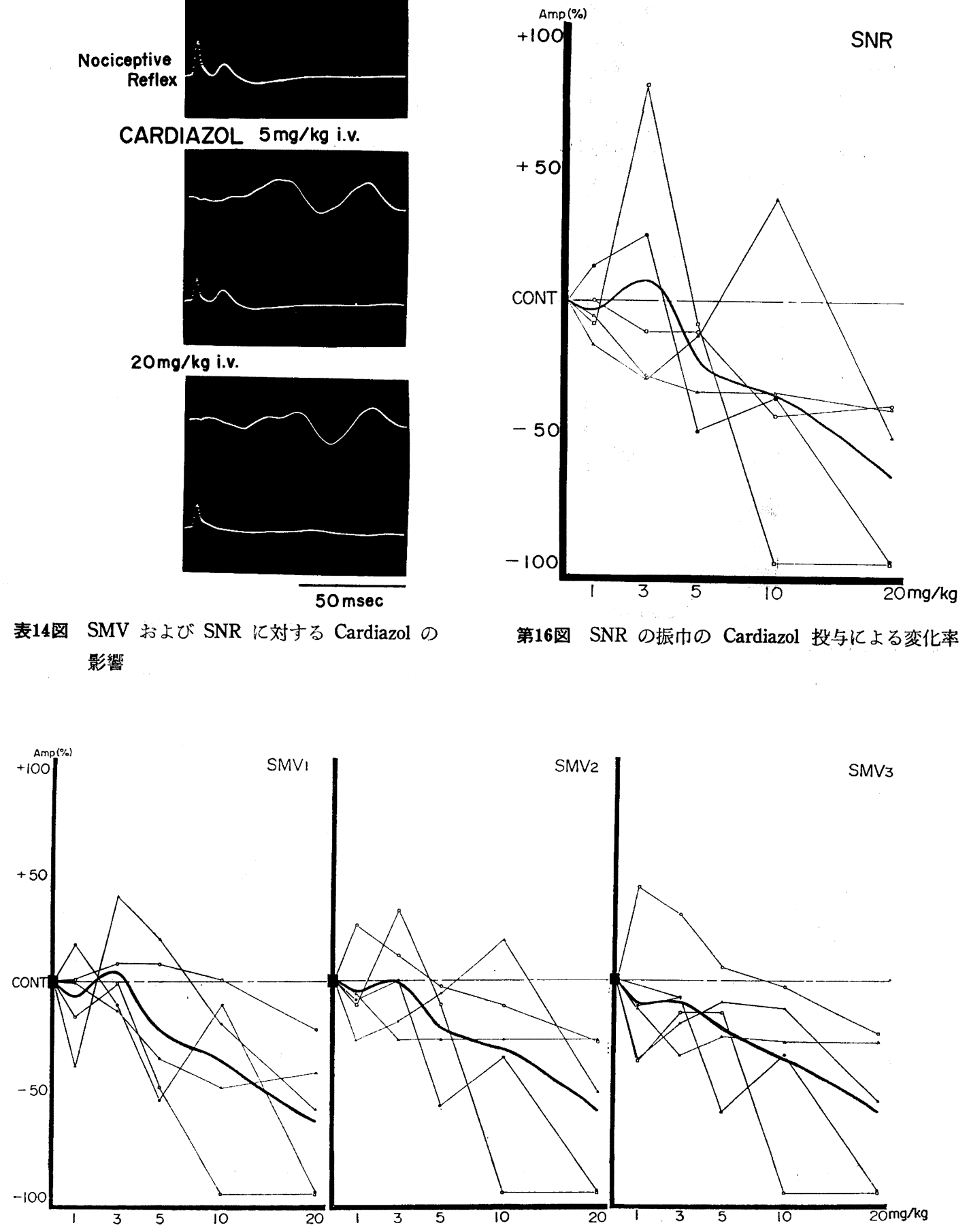

第15図 SMV の各 component 振巾の Cardiazol 投与に上る変化率 

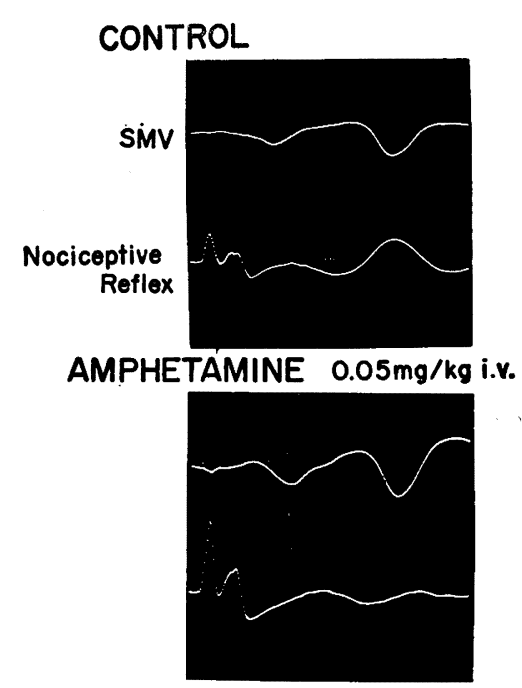

$0.3 \mathrm{mg} / \mathrm{kg}$ i.v.

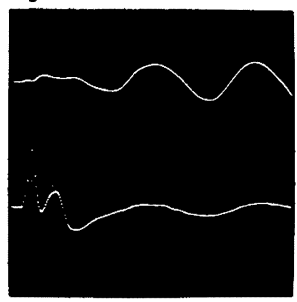

$50 \mathrm{msec}$

第17図 SMV および SNR に対する Amphetamine の影響 neuromodular とされる神経ペプチド TRH の影響につ いて検討した.

TRH tartrate は TRH として $0.5,1,5,10 \mathrm{mg} / \mathrm{kg}$ を耳静脈より投与した. その結果, 第11，12図に示す通 り，SMV はいずれも投与量に比例して振巾の強い抑制 が認められた。

第13図に示すように SNR は, SMV に比して抑制は 軽度で， $1 \mathrm{mg} / \mathrm{kg}$ で最も著明であったが，それ以上では むしろ抑制が減弱する傾向が認められた。

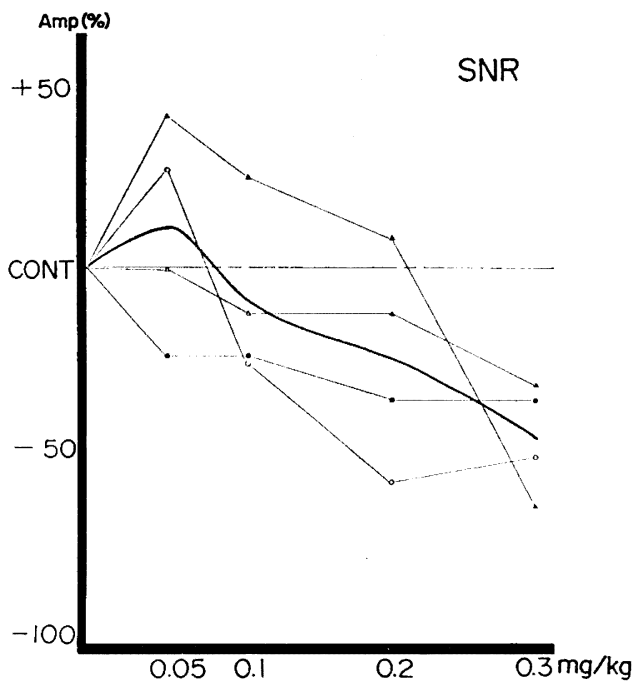

第19図 SNR の振巾の Amphetamine 投与による 变化率

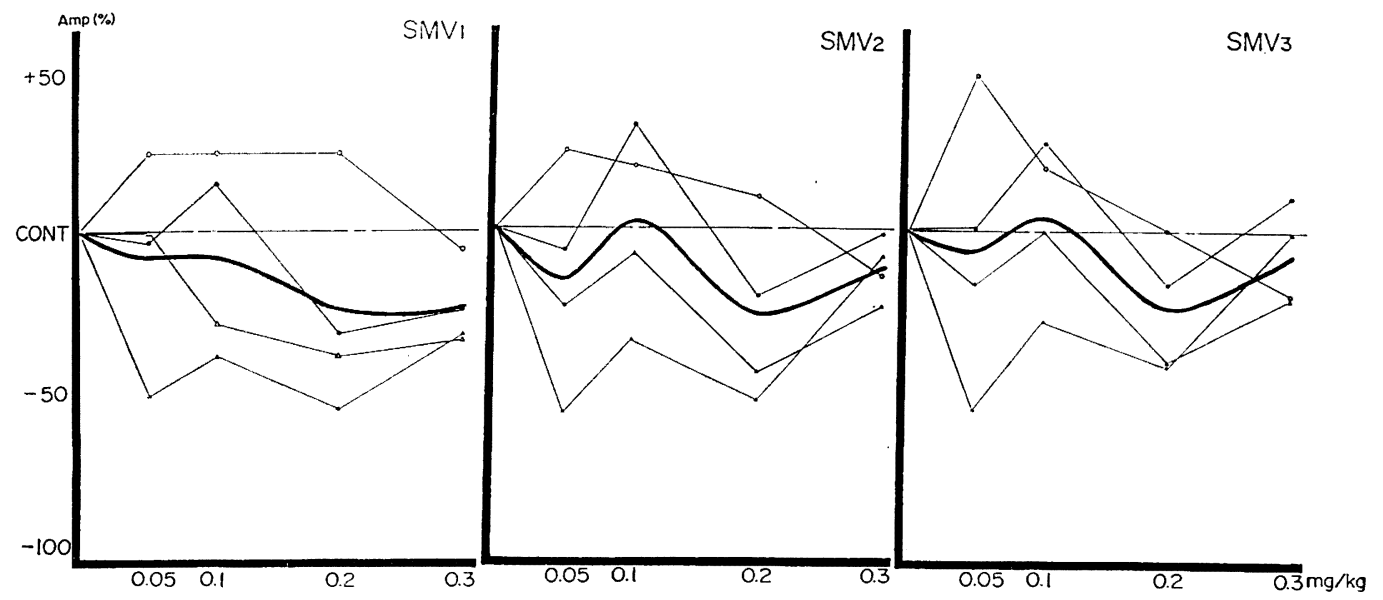

第18図 SMV の各 component 振ゆの Amphetamine 投与による変化率 


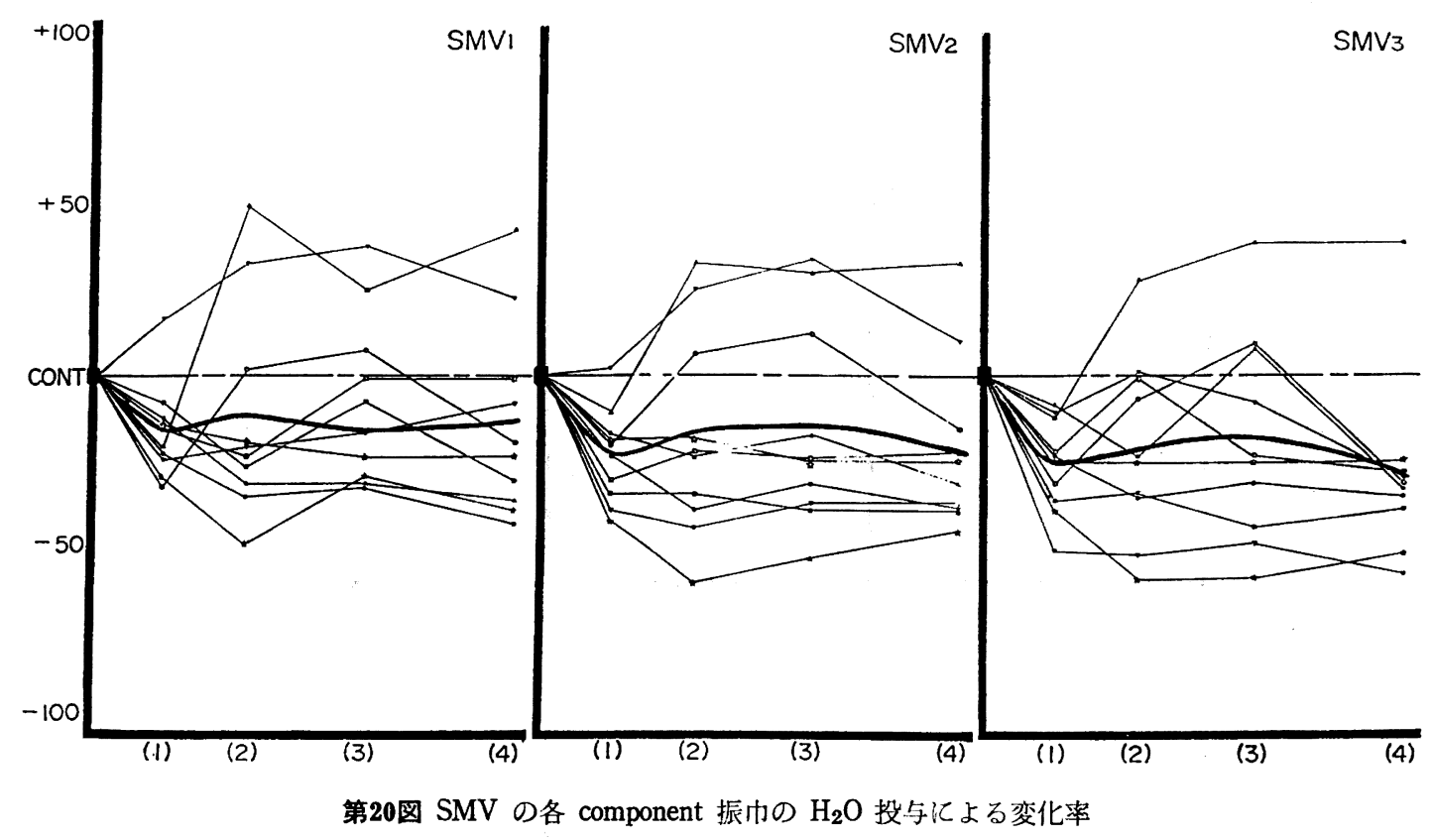

\section{4) Cardiazol の影整}

次に中枢興奮薬である Cardiazol の影響を検討した。

Cardiazol は，1，3，5，10，20mg/kgの各用量を耳 静脈に投与した．その代表例を第14图江示す．Cardiazol は, $5 \mathrm{mg} / \mathrm{kg}$ 以上の用量で投与量に比例して SMV の各 component おょび SNR の振市抑制した(第15，16図).

\section{5 ) Amphetamine の影霎}

次㳊も強力な中枢興奮薬の 1 つである Amphetamine の作用について検討した.

Amphetamine の投与量は，0.05，0.1，0.2，0.3の 4 用量とした。第17図はその代表例を示す。第18，19図は

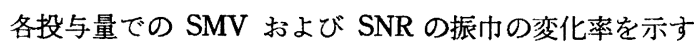
が，SMVでは概して軽度の抑制を示し，SNRでは投与 例に比例して抑制が観察された。

\section{6) 対照群 $\left(\mathrm{H}_{2} \mathbf{O}\right)$ の変化}

第20およ゙21図は, 対照として注射用蒸留水 $\left(\mathrm{H}_{2} \mathrm{O}\right)$ を投与した場合の变化を示した。

SMV の各 component は， $\mathrm{H}_{2} \mathrm{O}$ の投与によって， の振巾がかなり減少することがわかる.

SNR についても，この現象は同様に観察された。

\section{7 ）まとめ}

以上，坐骨神経刺激により，右上眼䀫部に誘発される SMV および前脛骨筋より誘導された SNR に対する諸 種中枢作用薬の影響をまとめると，第22，23図のように なる.
すなわ占，SMV に対しては，対照（注射用蒸留水） に比較して, Barbiturate では少量では振巾の増大がみ られ， $10 \mathrm{mg} / \mathrm{kg}$ 以上の多量になると振巾の著しい抑制が みられた。

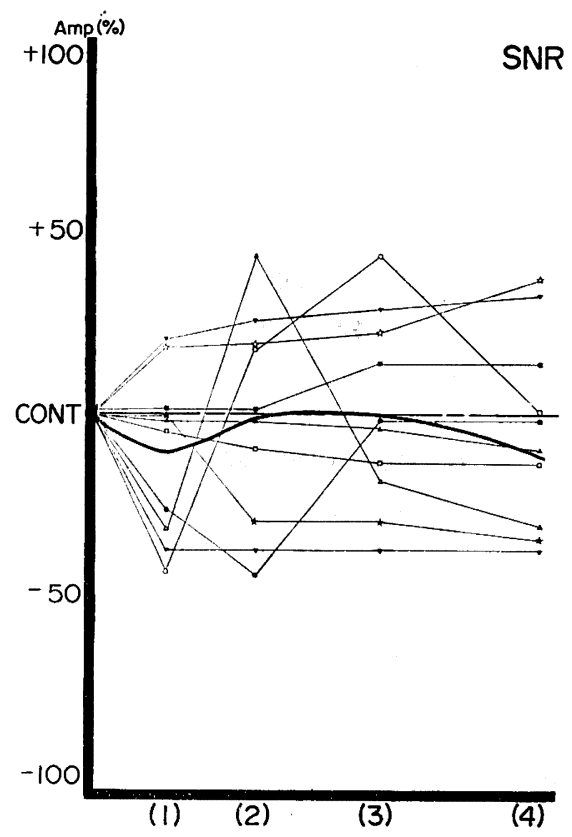

第21図 SNR の振巾の $\mathrm{H}_{2} \mathrm{O}$ 投与による変化率 


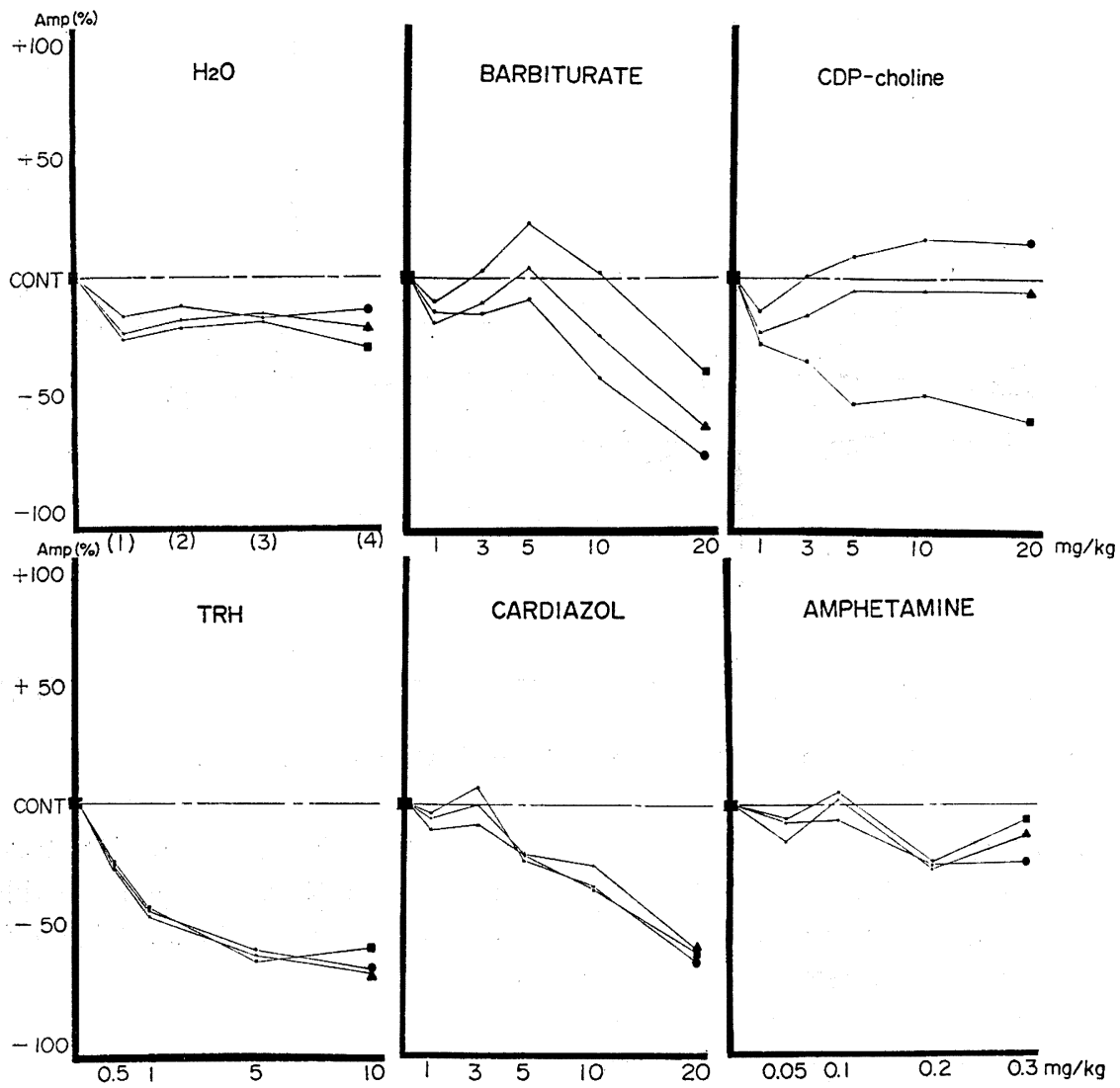

第22図 SMV の各 component 振巾の諸種中枢作用薬投与による变化率（まとめ） 注: 丸印は $\mathrm{SMV}_{1}$,三角印は $\mathrm{SMV}_{2}$, 四角印は $\mathrm{SMV}_{3}$ をあらわす.

CDP-choline では, $\mathrm{SMV}_{1}, \mathrm{SMV}_{2}$ の 2 つ component は, 投与量に平行して振巾の増大がみられるが, $\mathrm{SMV}_{3}$ はむしろ振巾が抑制される傾向が認められた。TRH, Cardiazol においては, いずれの用量においても振巾を 強く抑制し，用量反応関係が認められた。

SNR に対する影響は, CDP-choline のみが振巾の増大 を認めたが, そのパターンは異るものの, Barbiturate, Cardiazol および TRH ともに振巾の減少が認められた.

Amphetamine を投与した場合は, SMV, SNR ともに 抑制的に作用した.

II. 眼窝上神経刺激による上眼瞼 TMV および BR に関する実験

\section{A. 眼窝上神経刺激時の TMV および BR の波形}

一側 (右側) の眼窩上神経に 1 秒 1 回の頻度で電気刺 激を与えると, 同側の上眼䀫には, 坐骨神経刺激によっ
て誘発される SMV の場合と同様に，3つの component からなる microvibration が記録される、私たちはこれ を $\mathrm{TMV}_{1}, \mathrm{TMV}_{2}, \mathrm{TMV}_{3}$ と命名した.

また同時に右上眼䀫中央部に誘発される瞬目反射筋放 電 (Blink reflex discharge) は，2つの成分からなり， 私たちはこれを $\mathrm{BR}_{1}, \mathrm{BR}_{2}$ と呼ぶことにした.

第24図は，代表的な TMV および BR の波形で，第 5 表はそれぞれの頂点潜時を示している. 寸なわち, TMV は $32 \pm 10,53 \pm 11$, および $71 \pm 12 \mathrm{msec}$ (mean 士 S. D. ）の頂点潜時を持つ 3 つ成分からなり, BR は潜時の短い棘状波とこれに続く小さな波から構成され 常に 2 峰性で，それぞれの潜時は $3 \pm 0$ および $10 \pm 1$ msec (mean 土 S.D.) であった.

B. TMV および BR に対する諸種中枢作用薬の影豊 ついで，3つの component からなる TMV および $2 つ$ 


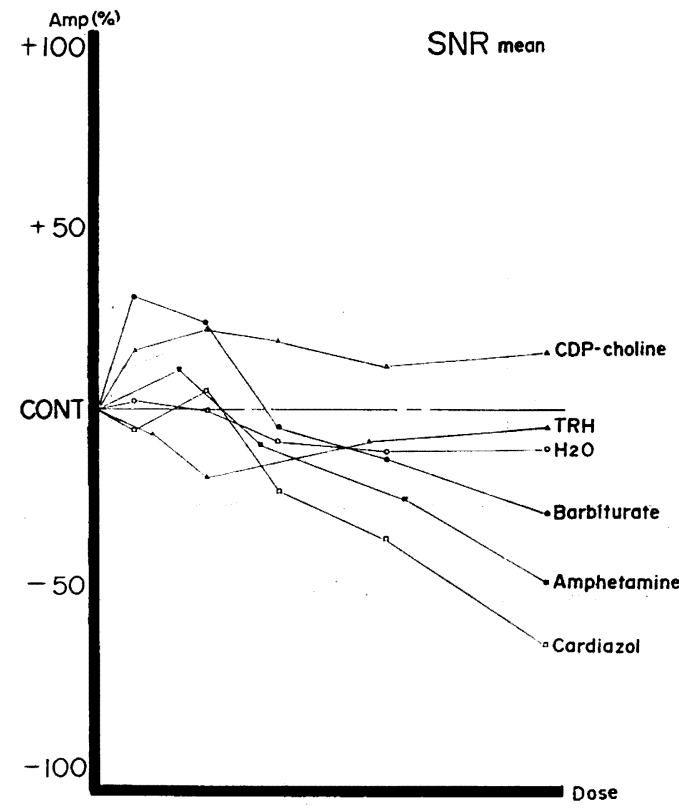

第23図 SNR の振巾の諸種中枢作用薬投与による 変化率（まとめ）

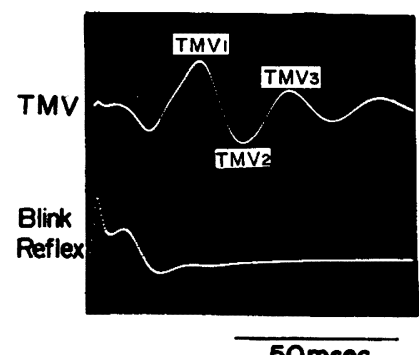

第24図 眼䈑上神経刺激により上眼䀫に誘発された TMV と BR

の component からなる BR の波形に対し, Barbiturate, CDP-choline, TRH, Cardiazol および Morphine の投与 がどのような変化をもたらすかを検討した。

\section{1 ) Barbiturate の影督}

Barbiturate は， 1，3，5，10および20mg $/ \mathrm{kg} の 5$ 用 量を耳静脈内に投与した。第25図は，同一のウサギにつ いて用量をかえた場合の実験例であり，第26，27図は実 験成績を 5 例についてまとめたものである.

この成績よりみると，TMVでは用量に相関して抑制 を認め, BRでは $1 〜 5 \mathrm{mg} / \mathrm{kg}$ までは弱い抑制がみられる
第 $\mathbf{5}$ 妻 TMV および BR の各 component の 頂点潜時

\begin{tabular}{|c|c|c|}
\hline \multicolumn{2}{|c|}{ Response } & $\begin{array}{c}\text { Peak Latency } \\
\text { (msec) }\end{array}$ \\
\hline \multirow{3}{*}{ TMV } & TMV1 & $32 \pm 10$ \\
\cline { 2 - 3 } & TMV2 & $53 \pm 11$ \\
\cline { 2 - 3 } & TMV3 & $71 \pm 12$ \\
\hline \multirow{3}{*}{ BR } & BR1 & $3 \pm 0$ \\
\cline { 2 - 3 } & BR2 & $10 \pm 1$ \\
\hline
\end{tabular}

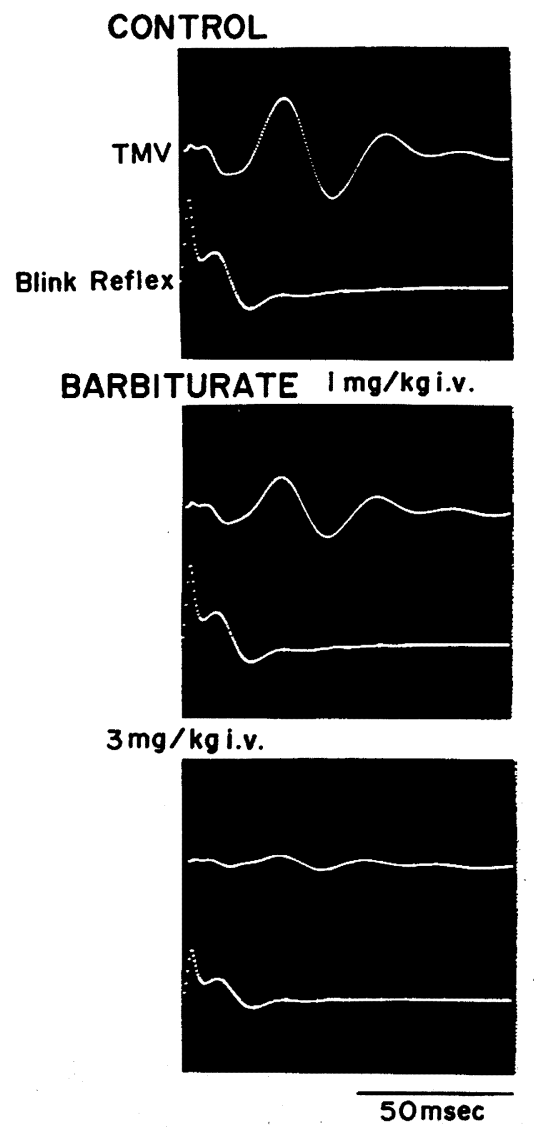

第25図 TMV および BR に対する Barbiturate の 影響 


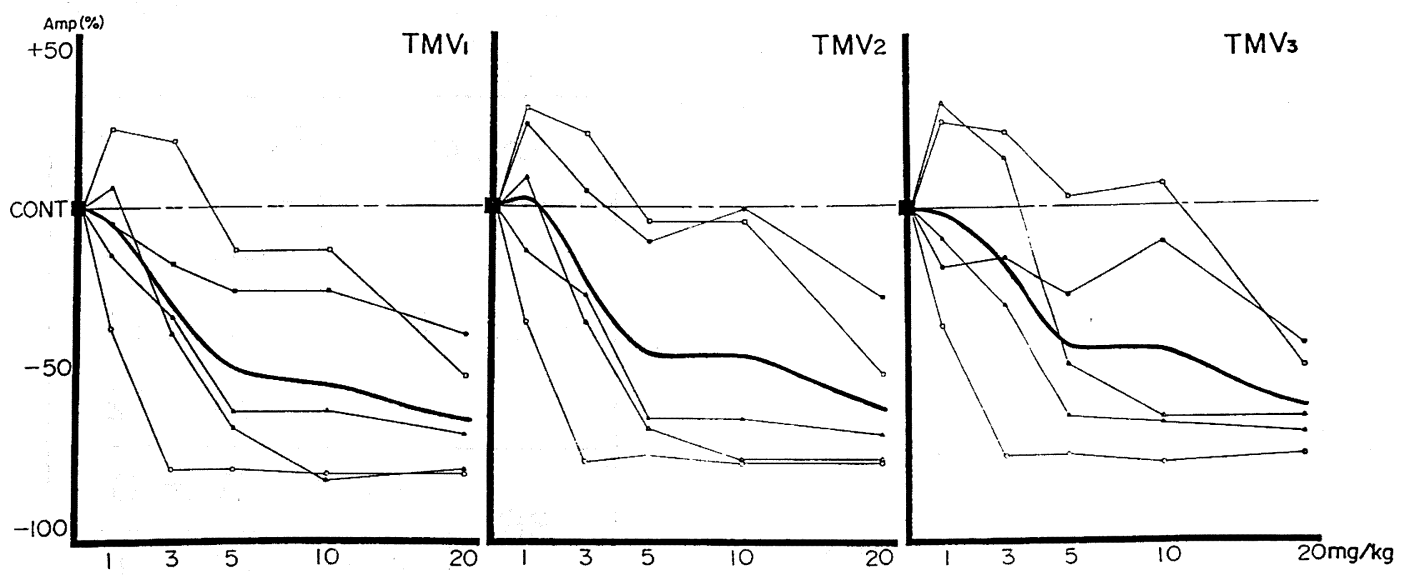

第26図 TMV の各 component 振巾の Barbiturate 投与による变化率

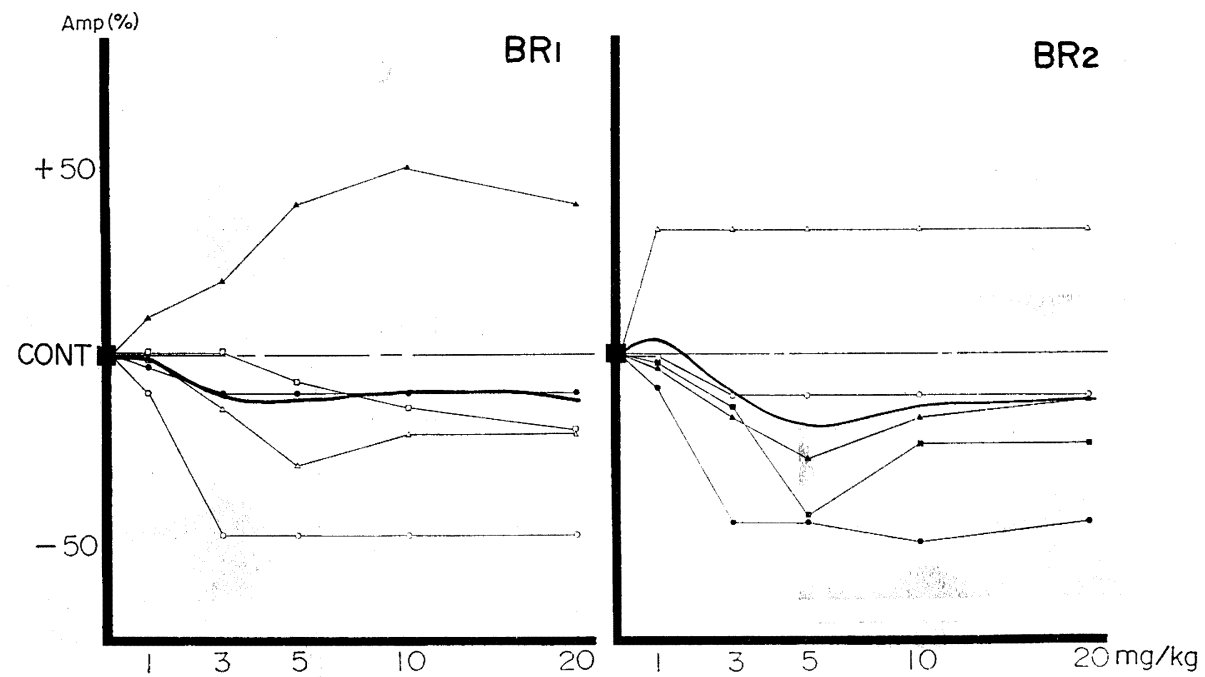

第27図 BRの各 component 振巾の Barbiturate 投与による変化率

が, 以後増量してもおおよそ10〜20\%程度の抑制を維持 するのみであった. すなわち, Barbiturate では, TMV は強く抑制されるが，BR ではそれ程抑制はされなかっ た.

\section{2 ) CDP-choline の影留}

次に CDP-choline の影響について検討した. 第28図 がその代表例であり，第29，30図はその成績它 5 例に ついてまとめたものである.この図表より，TMV の各 component は, 1 例を除き $1 \sim 5 \mathrm{mg} / \mathrm{kg}$ までは抑制し, 以後増量しても一定の抑制を維持する傾向がみられた。
一方， BR では 1 例学除き殆ど変化がみられなかっ た.

\section{3) TRH の影敬}

次に, TRH の $0.5,1,5,10 \mathrm{mg} / \mathrm{kg}$ を耳静脈に注入 し，その影響を観察した。第31図はその代表実験例で， 第32，33図はその成績を 5 例についてまとめたものであ る.

TMV では, 各 component とも増量と共に抑制が強 く認められた。一方，BR においても用量にほぼ相関し て振巾の抑制が認められた. 


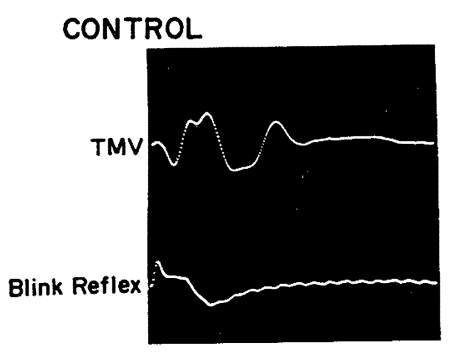

CDP-choline $10 \mathrm{mg} / \mathrm{kg}$ i.v.

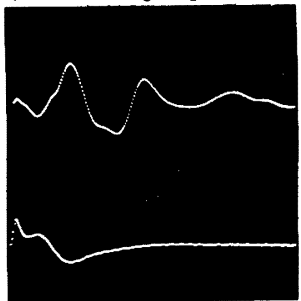

$20 \mathrm{mg} / \mathrm{kg}$ i.v.

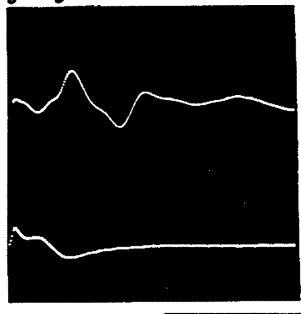

$50 \mathrm{msec}$

第28図 TMV および BR に対ちる CDP-choline の影響

\section{4) Cardiazol の影餢}

次に，中枢興奮薬である Cardiazol の影響を検討し た。第34図法その代表例を第35，36图は5 例についての 実験成績をまとめたものである.

この場合も, TMV の各 component においては, 増 量に従って振巾の抑制が観察された．BR では，1例を 除き $5 \mathrm{mg} / \mathrm{kg}$ までは振巾の弱い抑制が認められたが，そ れ以上増量しても，それ以上振洞減少することはなか った.

\section{5) Morphine の影啡}

次に鎮痛薬の Morphine による TMV および BR に 及ぼす影響を検討した。

第37図は代表実験例の波形ならびにその変化を示すも のであるが，TMV は著明に抑制され， BR も抑制され た.

第38図は, TMV の各 component 振巾に対する Morphine 投与の影響をその変化率で表わしたものである が，各 component 共著しく抑制された. 一方，BRは, TMV に対する程ではないが，約 $50 \%$ 程度振巾の抑制が 認められた（第39図).

6) 対照群 $\left(\mathrm{H}_{2} \mathrm{O}\right)$ の変化

最後に対照例として注射用蒸留水を投与した場合の变 化を記録した。

第40図はその実験例で，第41，42図は5例についての 実験成績である。

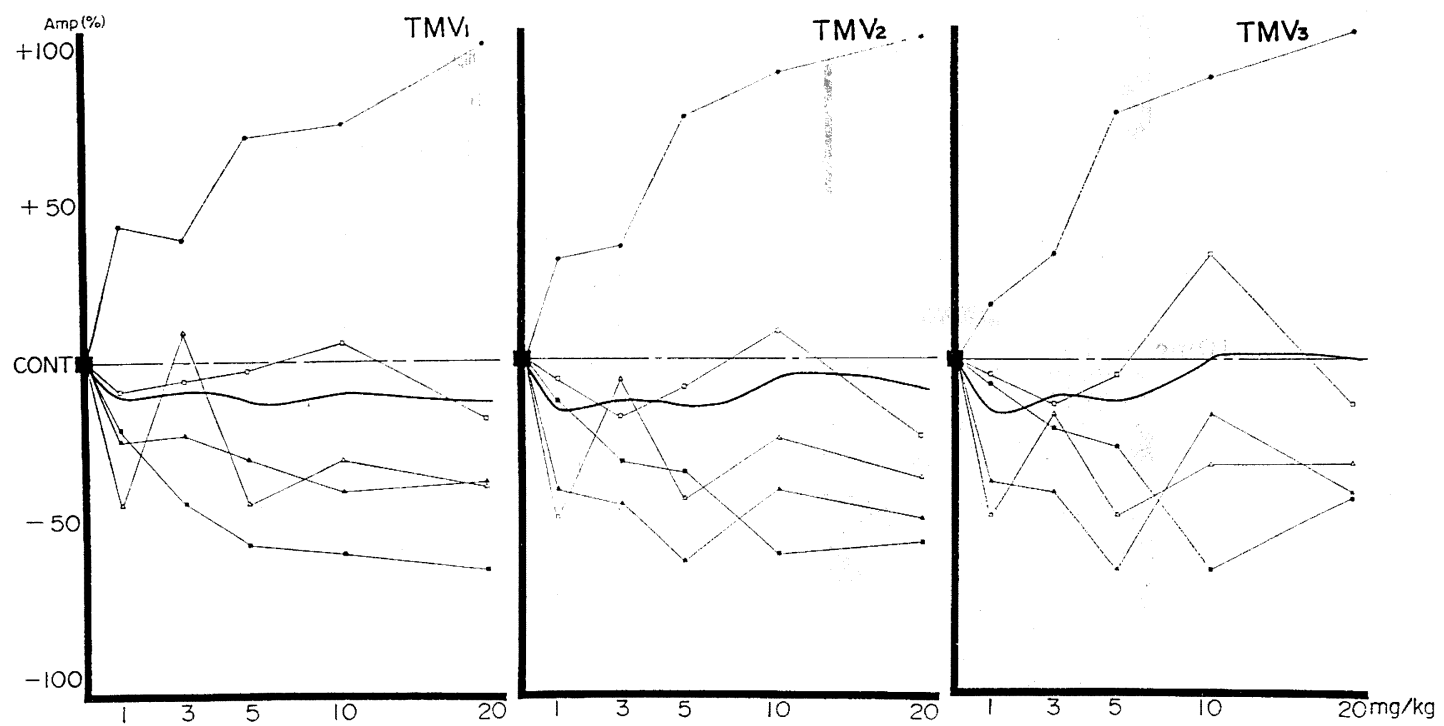

第29図 TMV の各 component 振巾の CDP-choline 投与による変化率 


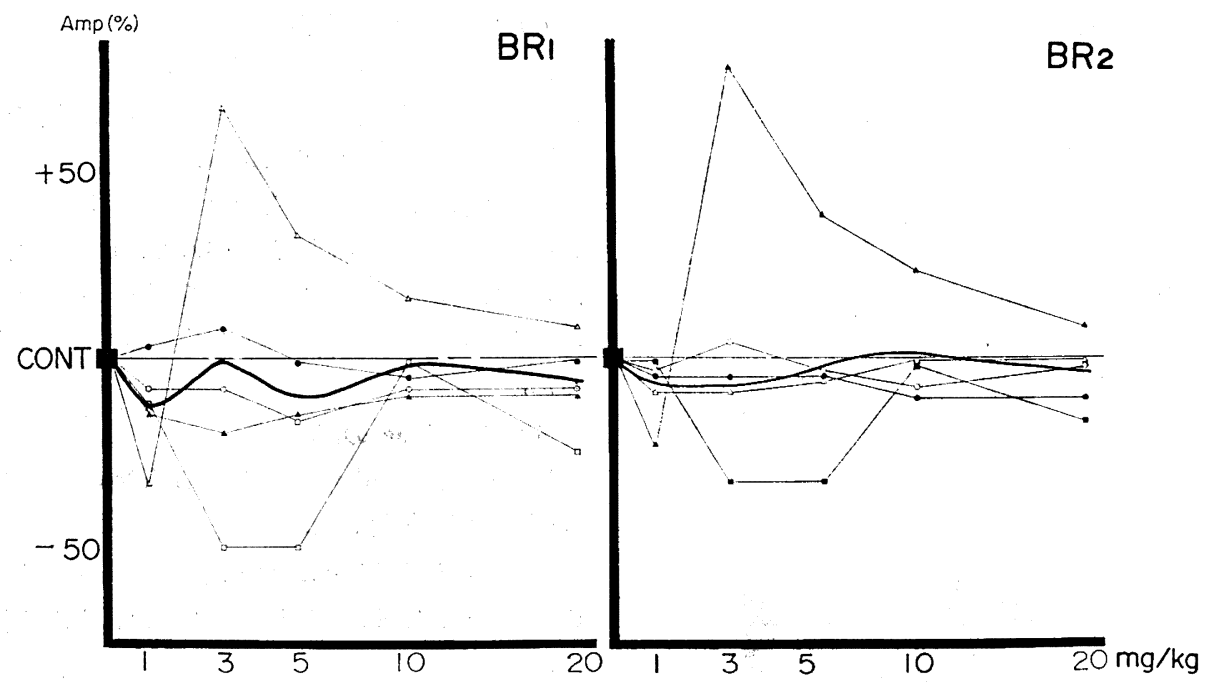

第30図 $\mathrm{BR}$ の各 component 振巾の CDP-choline 投与による变化率

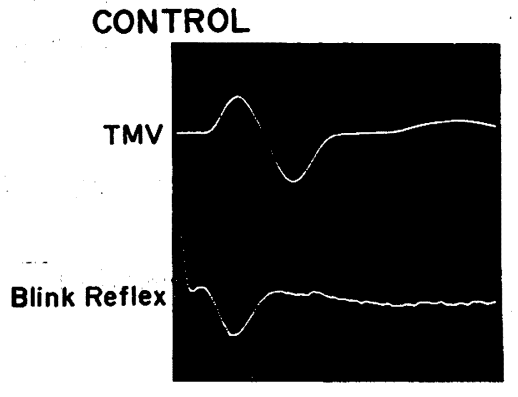

TRH $5 \mathrm{mg} / \mathrm{kgi.v}$.

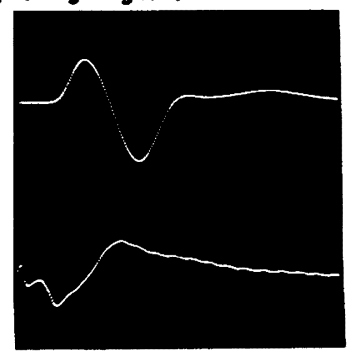

$10 \mathrm{mg} / \mathrm{kg} \mathrm{l.v.}$

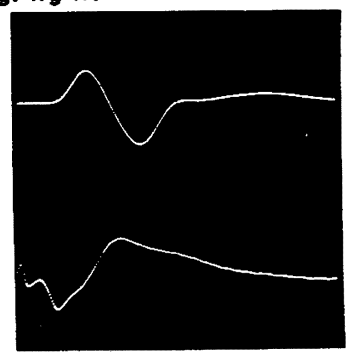

$50 \mathrm{msec}$

第31図 TMV および BR に対する TRH の影響
TMV および BR ともに注射用蒸留水の投与および刺 激のくり返しにより，各 component の振巾は軽度なが ら減少する傾向が認められた。

7 ) まとめ

以上, Barbiturate, CDP-choline, TRH, Cardiazol お よび Morphine の 5 種の中枢作用薬および対照としての

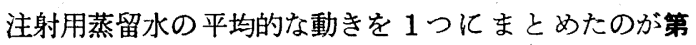
43および第44図である.

第43図は TMV についての比較であるが，今回使用 した投与量において最も強い振巾の抑制がみられたのは Morphine で, $6 \mathrm{mg} / \mathrm{kg}$ 以上で $85 \%$ の振巾減少がみられ た.ついで Barbiturate で, $5 \mathrm{mg} / \mathrm{kg}$ 以上で $50 \sim 60 \% の$ 减少を, TRH では0.5〜1.0mg/kgで既に25〜40\%の振巾 减少がみられ，10mg/kgでは50〜 60\%の抑制が観察され た.ついで Cardiazol は, 対照の注射用蒸留水の pattern に比較すると，やや抑制傾向がみられる程度で，大きな 変化はなかった. CDP-choline については, 全体として あまり振巾に変化はないが，対照と比較すると相対的に さしろ振巾の減少を抑えている傾向が認められた。

一方, BR については第44図にみる如く, 各薬物ごと の変化は, ほぼTMV の動きに平行しているが, 全体と してみるとあまり大きな变化は認められなかった.

また各 component の間には，振巾に対する影響はほ ぼ同程度で差異は認められなかった。

以上をまとめると, Barbiturate と TRH は TMV の 振巾に対して抑制的に, CDP-choline は促進的に働き, Cardiazol はやや抑制的であった. BR は, ほぼTMV 

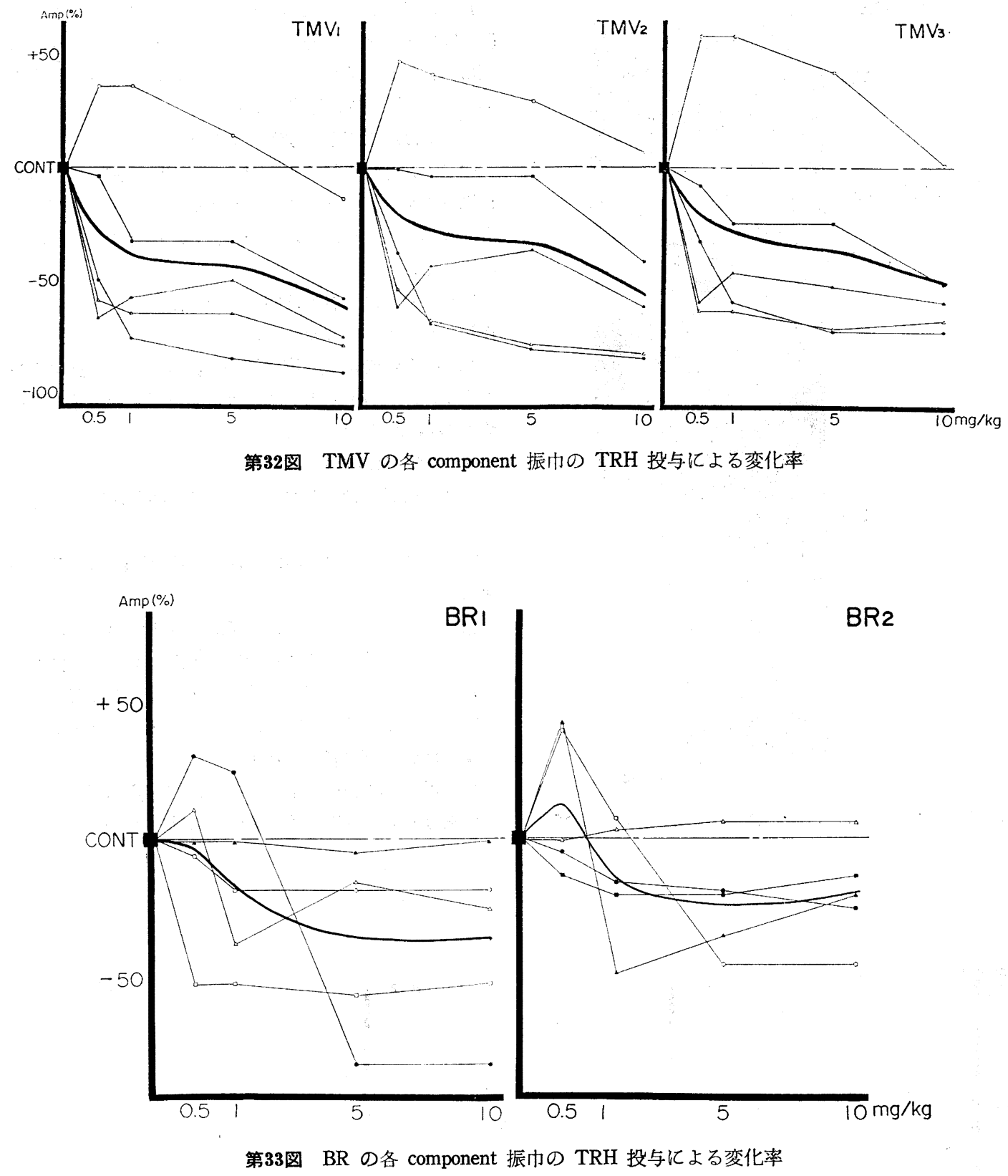

の動きに平行した.

\section{C. 中枢破壊の TMV および BR への影第}

$\mathrm{TMV}$ および BR の各成分が, 脳内のいかなる部位と 関連しているかを明らかにするために視床核群を中心に 局所破壞実験を行った.

\section{1）VPM（後内側腹側核）の破塿}

まず, 視床特殊核の1つである VPM の破壊を行っ た。第45図はその1例を示す，TMVの各成分は，VPM の破壊によって振巾は減少するが, BR の振巾は逆に増 強された。 


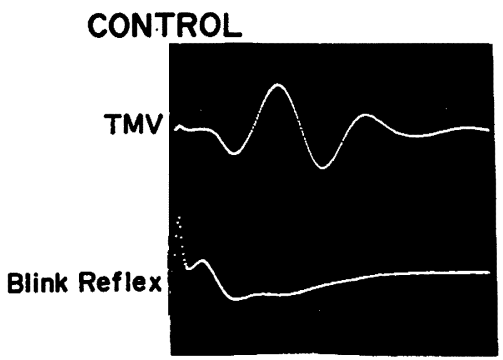

CARDIAZOL Img/kgi.v.

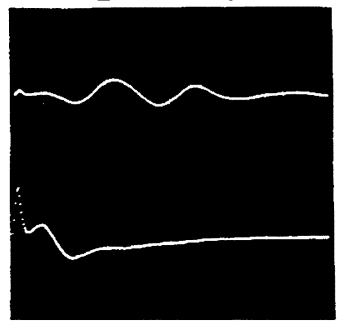

$10 \mathrm{mg} / \mathrm{kg}$ i.v.

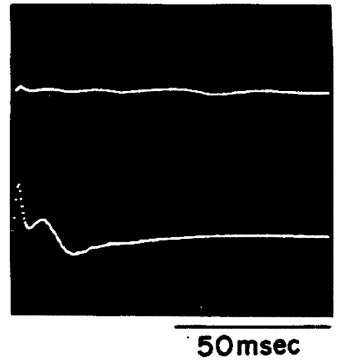

第34図 TMV および BR に対する Cardiazol の影餶
実験例 9 匹の TMV および BR の各成分の变化は, それぞれ第46，47図に示した，TMV の各成分は $1 〜 2$ 例を除いていずれも振巾は減少し，これとは逆に BRの 振巾は，概ね増大を示した。第48図は，これら9 例の VPM の破壊部位の組織図である.

\section{2) VPL（後外側腹側核）の破壊}

同じく知覚中継核の1つである VPL の破壊による実 験例を第49図に示す．この場合も破壊によってTMVの 各成分の振巾は抑制され，一方，BR は促進される傾向 を示した。

第50，51図は，各実験例の個々の記録データをグラフ 化してまとめたものである.

TMV の各成分は, 実験例の大部分において振巾の減 少を認め，一方 BR の各成分は増大を示した。第52図は VPL の破壊部位を示す.

\section{3） VL（外腹側核）の破壊}

次に非感覚性の中継核である VL の破壊実験を行っ た.

第53図は，代表実験例における TMV および BR の 波形を示す.

第54，55図にみるように，VL の破壊の場合に注， $\mathrm{TMV}$ および BR ともに振巾増大に向うものと，振巾減 少に向うものが相半ばする成績であった．第56図はこれ ら11例における VL 破壊部位を示寸組織図である.

\section{4) RET (網様核) の破懐}

次に視床非特殊核の 1 つである RET の破壊を行った. 第57図はその代表実験例，第58，59図は実験例すべてに

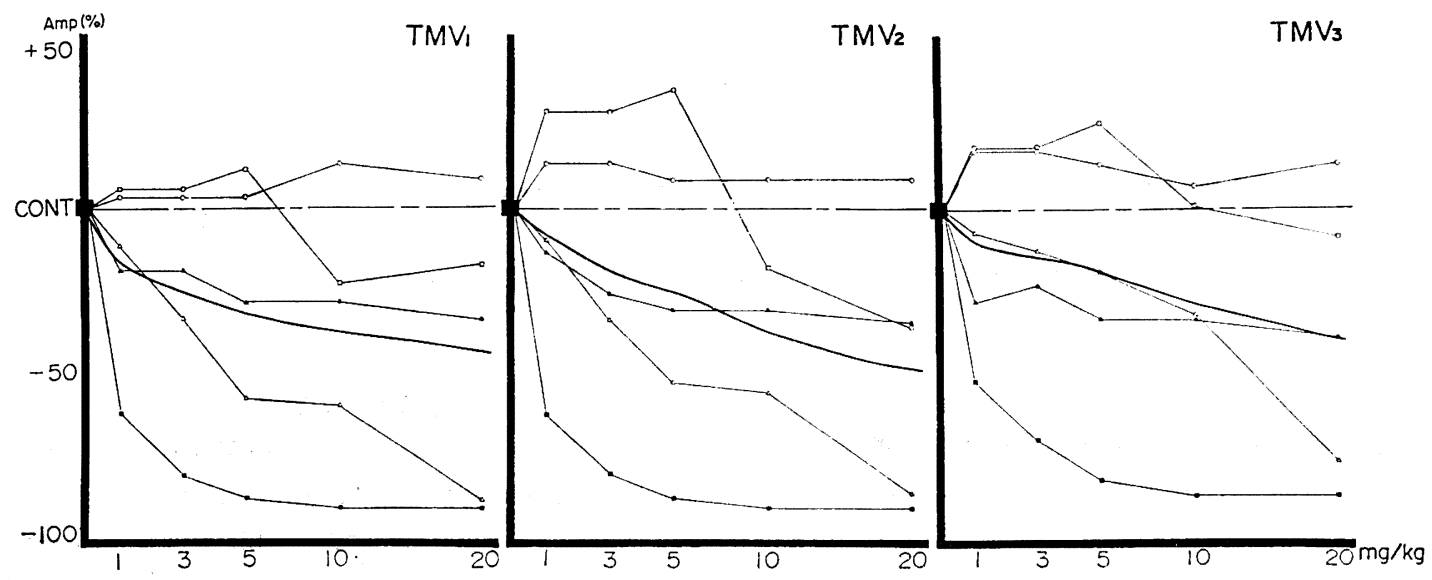

第35図 TMV の各 component 振巾の Cardiazol 投与による变化率 


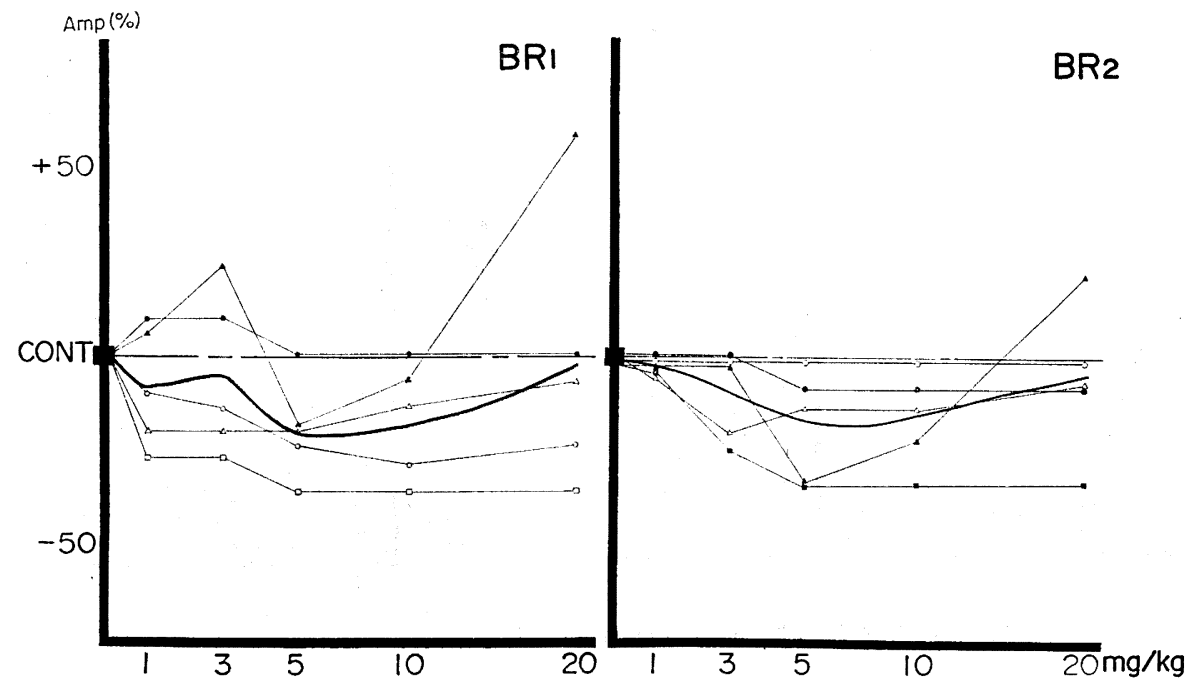

第36図 BR の各 component 振巾の Cardiazol 投与による变化率

\section{CONTROL}

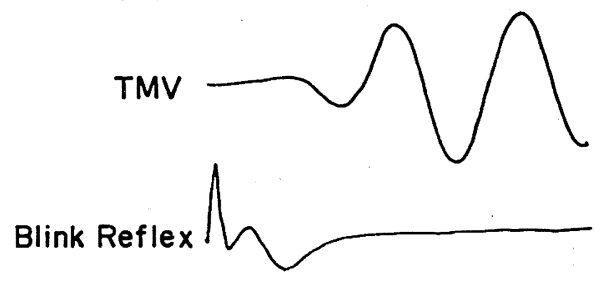

MORPHINE Img/kgi.v.
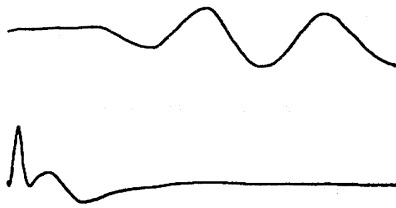

$10 \mathrm{mg} / \mathrm{kg}$ i.v.

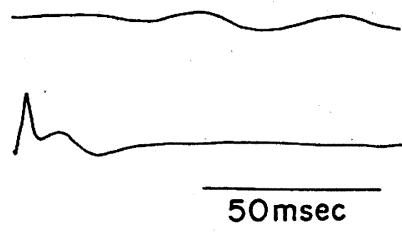

第37図 TMV および BR に対する Morphine の影響
ついて振巾の変化率をまとめたものである.

また第60図は，破壊部位の組織図を示した。

この場合も，TMV および BR ともに各成分の振斿 増大するものと減少するものに分かれたが，TMVにつ いては振巾減少を示すものが多く, 一方 BR では振巾増 大を示すものが多かった。

\section{5）VML（視床腹側核中間部外側部）の破壊}

VML は，VPL およびVPM の近傍に位置し，視床腹 側核の 1 部をなしている. 8 例を対象に，40 volt 30 秒 の通電を行い, 同部位の電気凝固を行った.

その代表実験例の波形，実験例すべての TMV およ び $\mathrm{BR}$ の各成分の変化率拉よび破壊部位の組織図を，そ れぞれ第61，62，63，64図に示した。

VML の破壊では，殆どすべての例で TMV の各成分 の振巾注減少し,一方 BR は增大した。

6) VA (前腹側核) の破壊

視床の非特殊核汇属するVA の破壞実験では, TMV の振巾が増大するものと減少するものとが，ほほ同数で あった，BR では，1例を除き振巾は増大した。第65図 は，VA 破壊による TMV および BRの各成分の波形 の変化をあらわし，第66，67，68图は TMV の各成分 の変化，BR の変化，そして破壊部位を示す組織図であ る.

\section{7）CM (正中中心核) の破塤}

VA と同様，視床非特殊核に属する $\mathrm{CM}$ を破壊する と, TMV の振巾は添ぼ完全に消失するが，一方 BR の 振巾は著しく増大した。 とくに BR の著明な振巾の増大 


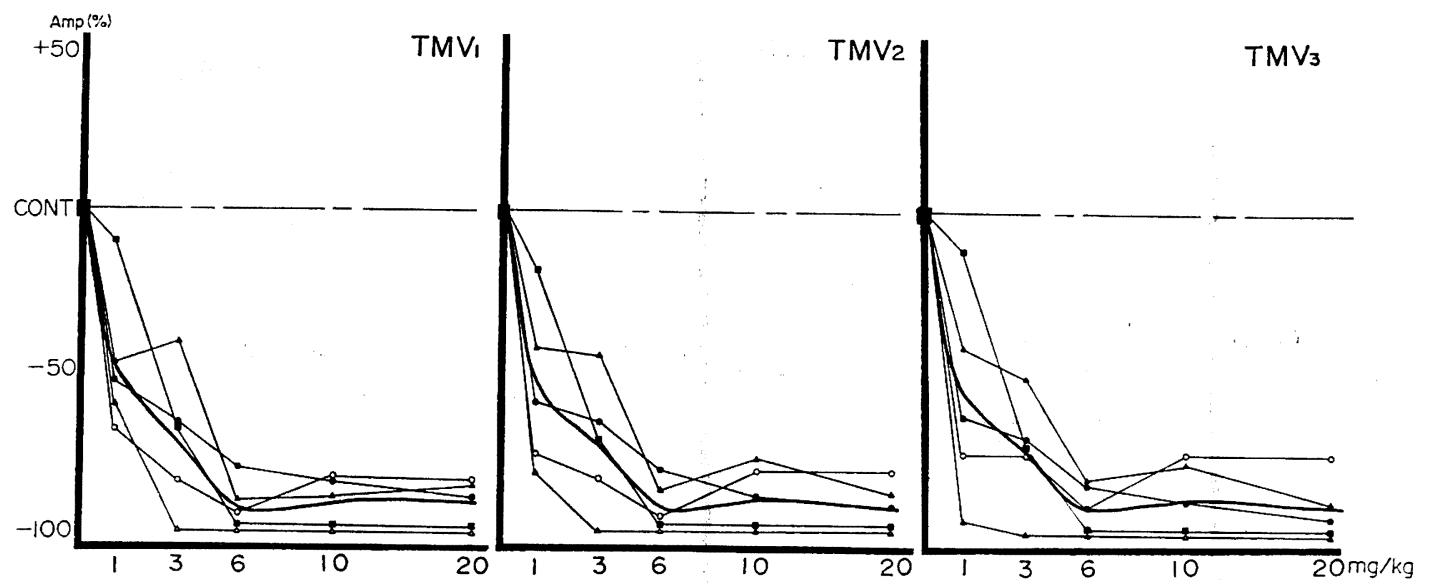

第38図 TMV の各 component 振巾の Morphine 投与による变化率

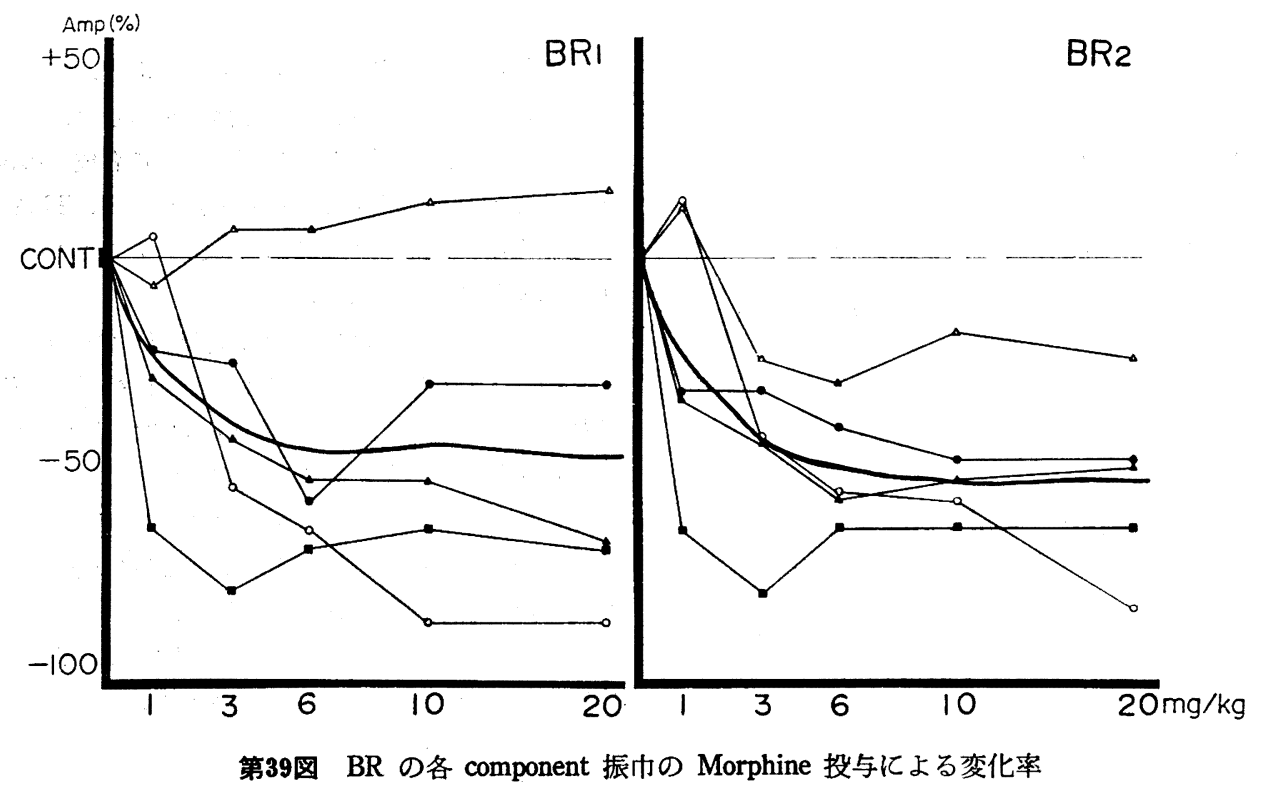

は, 他の中枢神経組織の破壊時には見られないほどのも のであった、第69，70図はその実験例の波形及び破壊部 位を示す.

8) IC (内包) の破壊

IC は，尾状核，レンズ核および視床の間に位し，大 䏚との主要な上行性, 下行性伝導路を担う膨大な投射線 維の集合個所であり，臨床的には極めて重要な部分とさ れている. 第71図は, 内包破壊時の実験例の波形を示
す. 実験例 6 例のうち $\mathrm{TMV}_{1}$ の振巾が増大したもの 3 例, 減少したもの 3 例で他の component むほほ同様で あった（第72図）。

また BRは, TMV の動きに平行して増大または減少 した (第73図). 第74図は，IC の破壊部位を示す.

9) STH（視床旁下部）の破壊

次に視床旁下部(subthalamus) を破壊した場合のTMV および BR の波形を示す（第75図). 


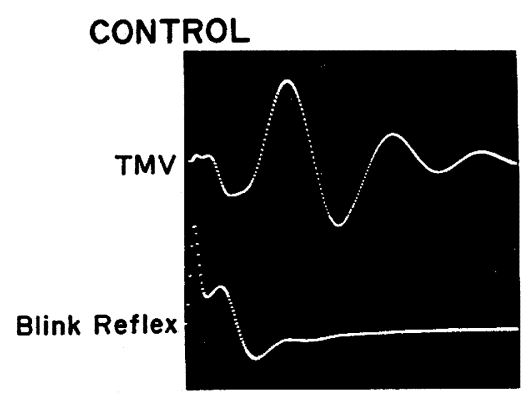

$\mathrm{H}_{2} \mathrm{O} 0.1 \mathrm{ml} / \mathrm{kgi.v}$.

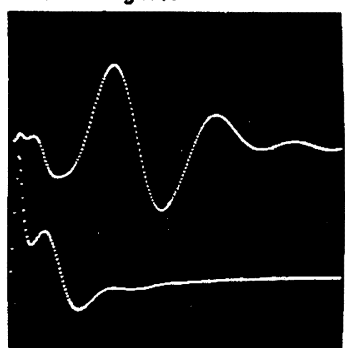

$0.2 \mathrm{ml} / \mathrm{kgi.v}$.

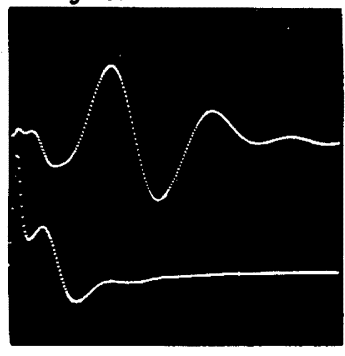

$50 \mathrm{msec}$

第40図 TMV および BR に対する $\mathrm{H}_{2} \mathrm{O}$ の影響
STH 破壊時の特徴は，これまで述べてきた部位の破 壊では，概ね TMV の各 component はパラレルに振巾 増大もしくは減少を示してきたが，それと異って $\mathrm{TMV}_{1}$ は振巾減少を示すのに対して, $\mathrm{TMV}_{2}, \mathrm{TMV}_{3}$ そして $\mathrm{BR}_{1}, \mathrm{BR}_{2}$ の順に次第に振巾増大への向う成績であった (第76, 77図). 第78図は STH の破壊部位を示す.

\section{0）OT (視索) の破壊}

第79図は OT 破壊時の TMV 及びBR に及ぼす影響 をみた 1 例の波形である. 実験例 4 例のうち 1 例のみが $\mathrm{TMV}, \mathrm{BR}$ 共に振巾の増大をみたが, 他の 3 例は TMV において不変ないし減少，BR においては不変であった

(第80，81図)。第82図は，これら4例の OT 破壞部位 を示す組織図である。

\section{1）LP（後外側核）の破壊}

次に連合核群（視床特殊核）の1つで，高次認識機能 にかかわると考えられている LPを破壊した（第83図）。 破壊実験を行った 4 例のうち，3例は TMVの各成分の 振巾は減少を示した（第84図）.

$\mathrm{BR}$ については, $\mathrm{BR}_{1}$ では 3 例が振巾増大，1例不 変, $\mathrm{BR}_{2}$ は 2 例が振巾増大, 1 例不変, 1 例は振巾が減 少した（第85図).第86図は LP の破壊部位を示す.

\section{2） RF (中脳網様体) の破壊}

中脳網様体は，感覚上行路の側枝から活動をうけて賦 活され直接または視床下部を介して大脸皮質を賦活する と共に, 視床の非特殊核群の活動に強い影響を与えてい る. 第87図は, RF 破壊時の実験例の波形であるが, TMV は強く抑制され，逆に BR は増大している. 第88， 89図は，これらの成績をまとめたものであるが，TMV

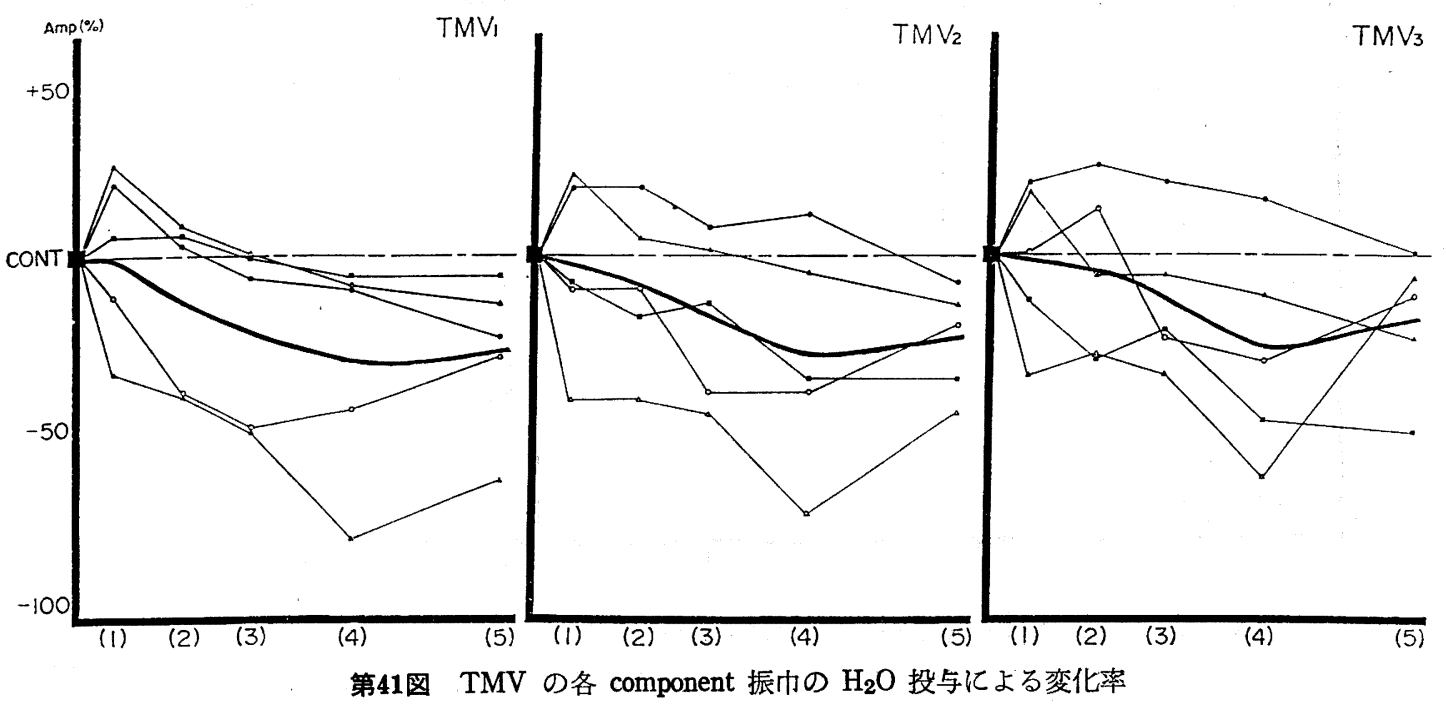




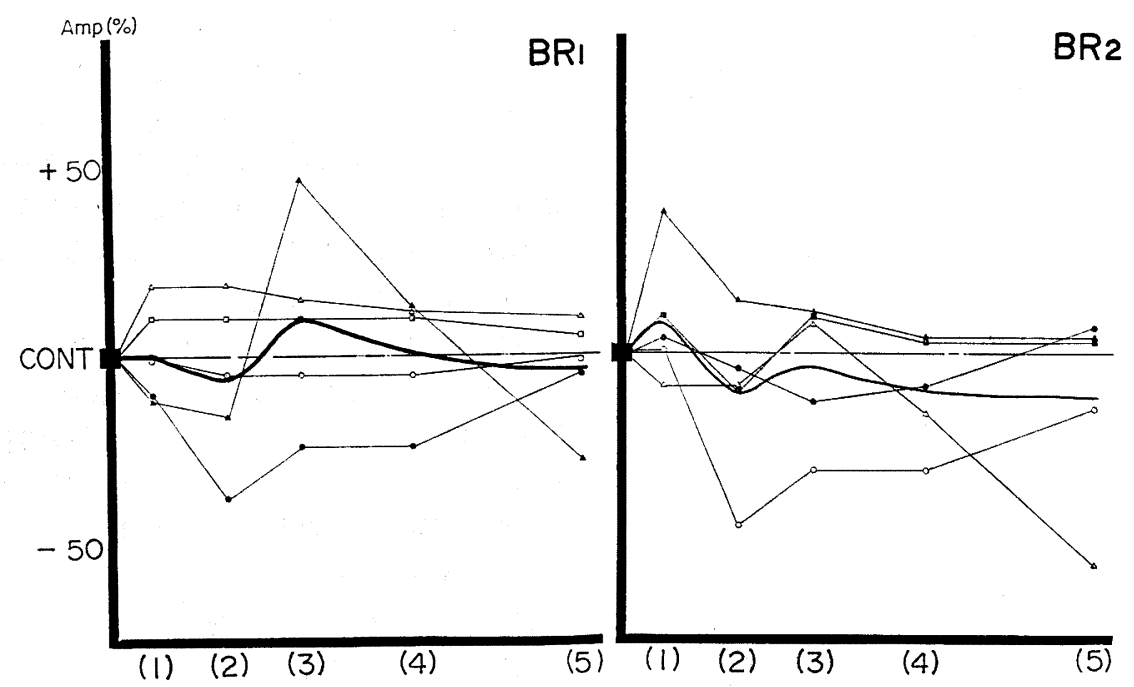

第42図 $\mathrm{BR}$ の各 component 振巾の $\mathrm{H}_{2} \mathrm{O}$ 投与による变化率
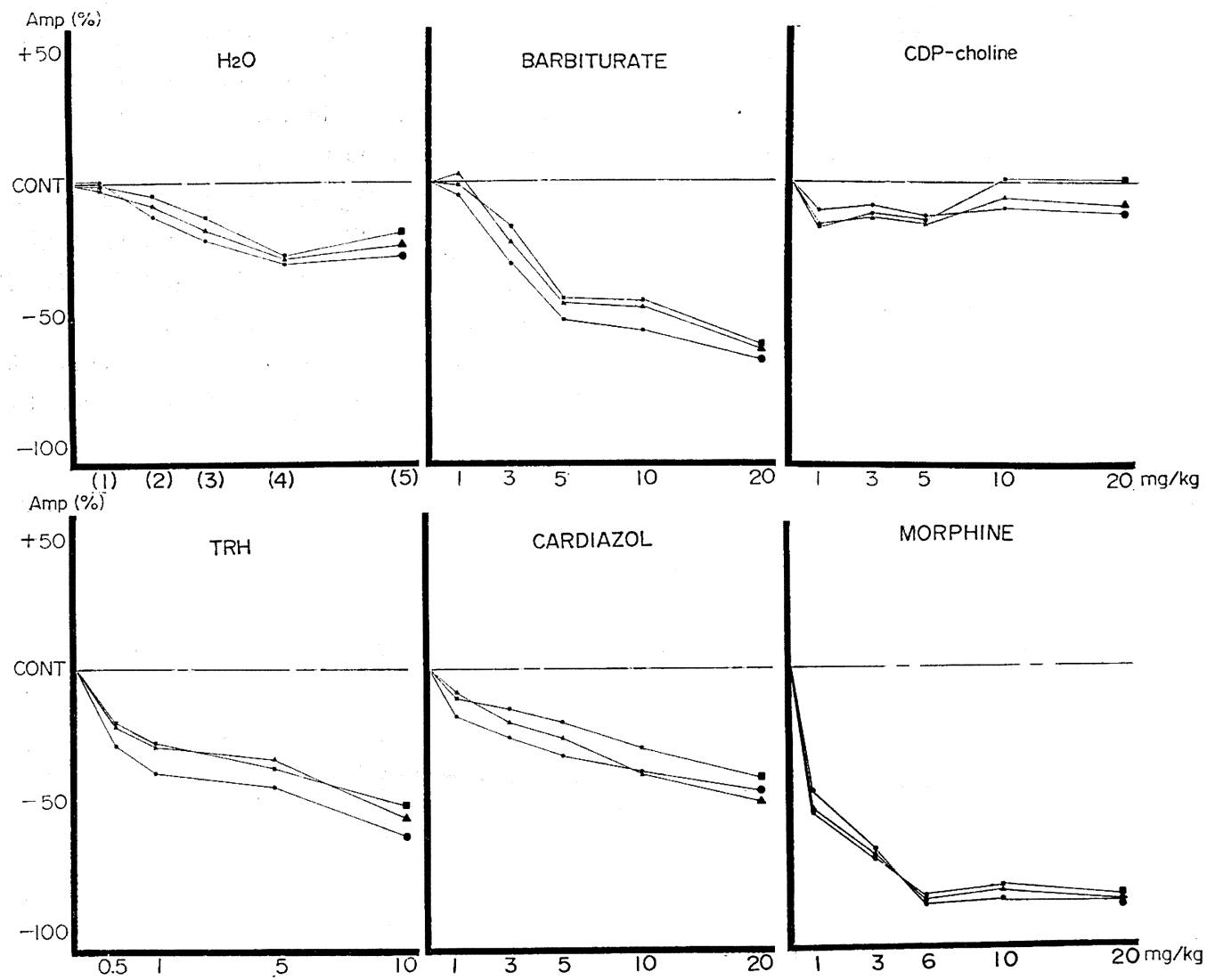

第43図 TMV の各 component 振巾の諸種中枢作用薬投与による变化率（まとめ）

注: 丸印は $\mathrm{TMV}_{1}$ ，三角印は $\mathrm{TMV}_{2}$ ，四角印は $\mathrm{TMV}_{3}$ をあらわす. 


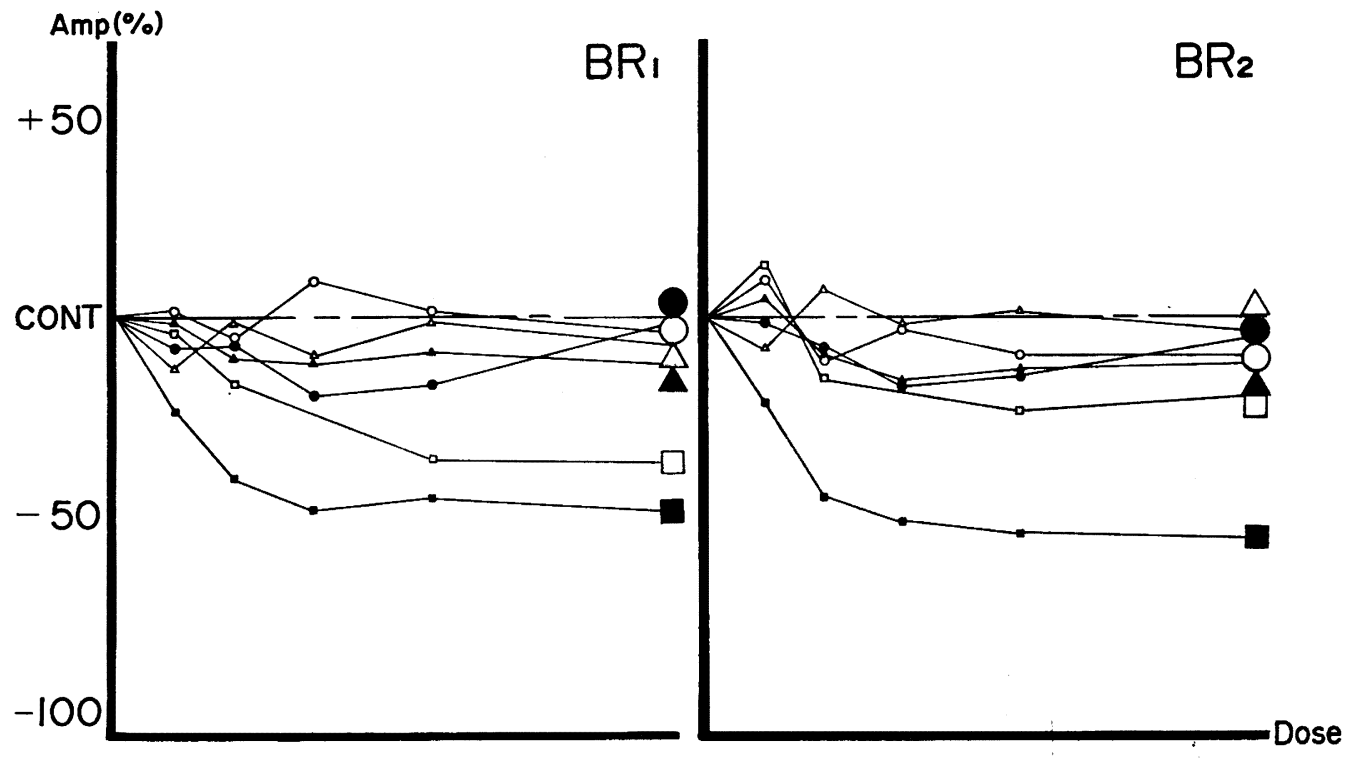

第44图 BR の各 component 振巾の諸種中枢作用薬投与による変化率（まとめ）

注 : $\triangle$ Barbiturate, $\triangle \mathrm{CDP}$-choline, $\square \mathrm{TRH}, \bigcirc$ Cardiazol, $\square$ Morphine, $\bigcirc \mathrm{H}_{2} \mathrm{O}$

CONTROL

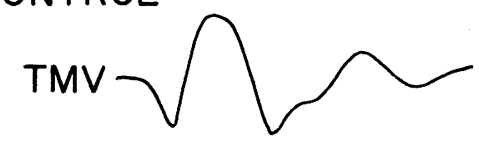

BR $h$

VPM LESION

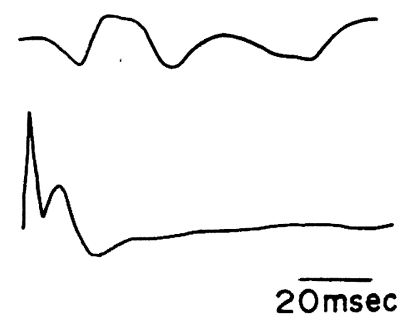

第45図 TMV およびBR に対する VPM 破壊の影響

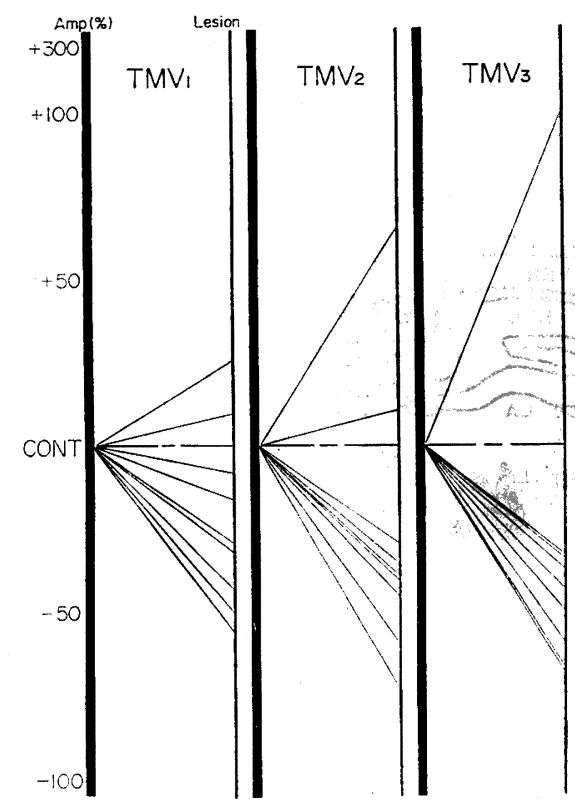

第46図 TMV の各 component 振巾の VPM 破壊 による変化率 


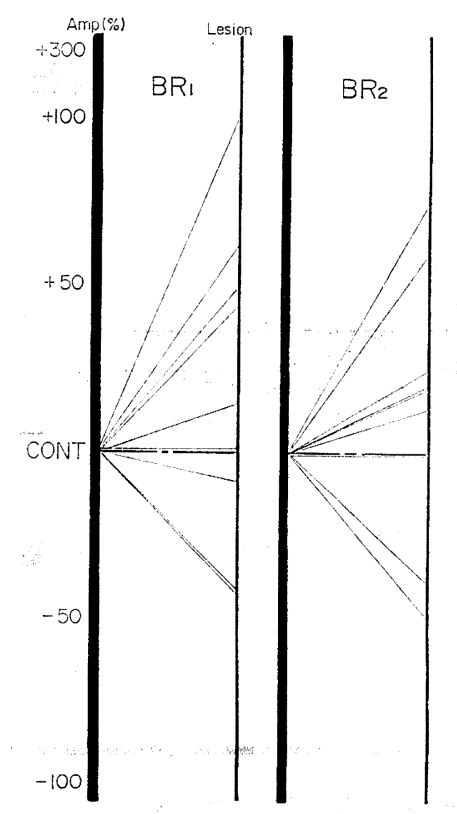

第47図 BR の各 component 振巾の VPM 破壊 による変化率

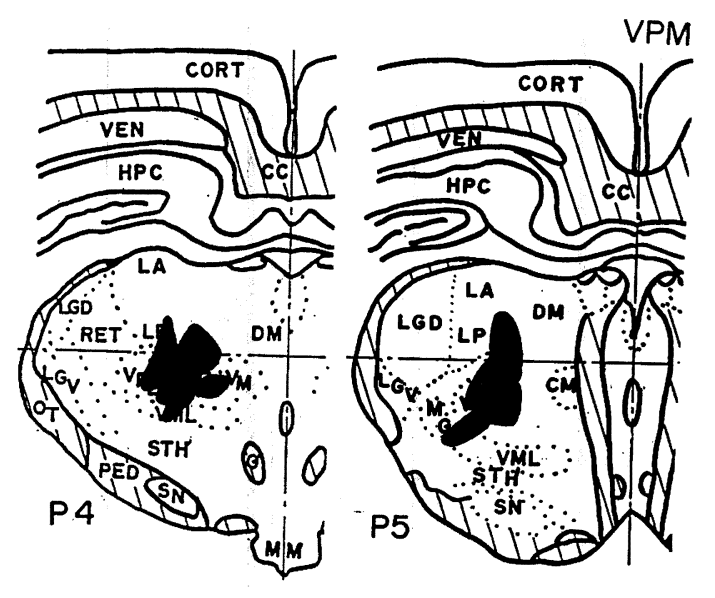

第48図 VPM の破壊部位

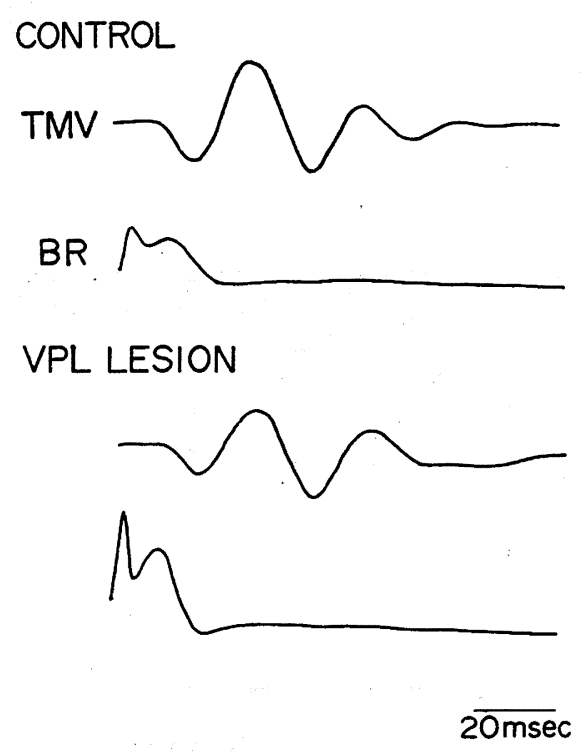

第49図 TMV および BR に対する VPL 破壊の影響

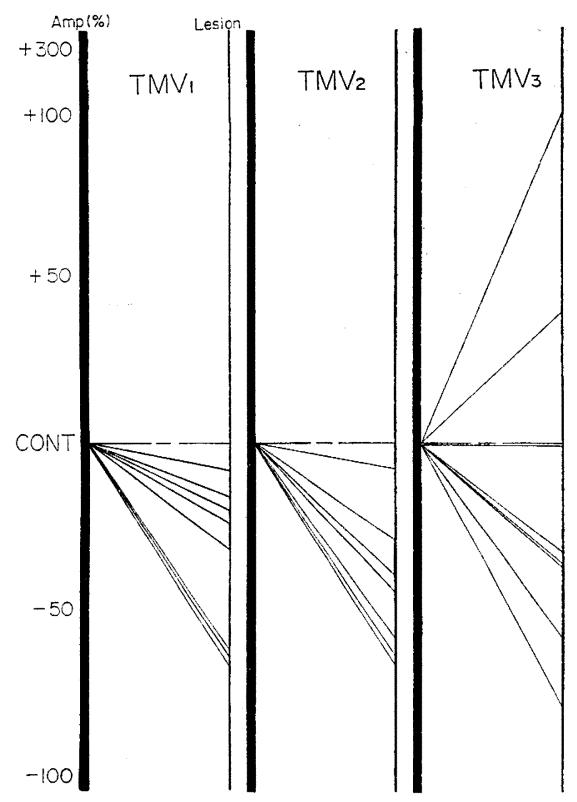

第50図 TMV の各 component 振巾の VPL 破壊 による変化率 


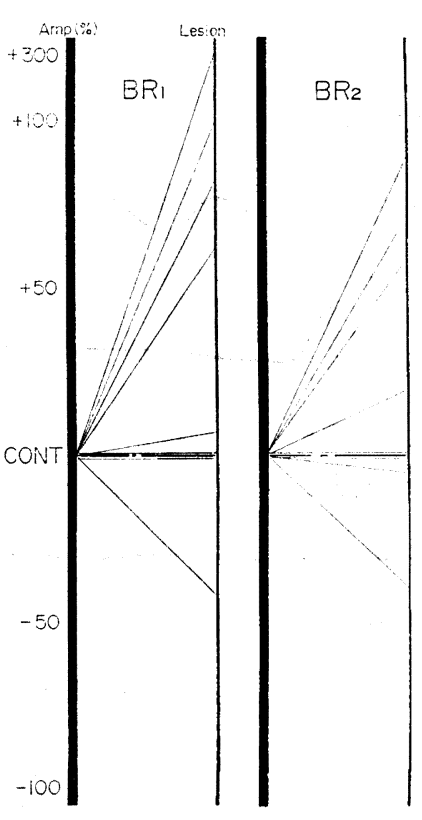

第51図 BR の各 component 振巾の VPL 破壊 による变化率

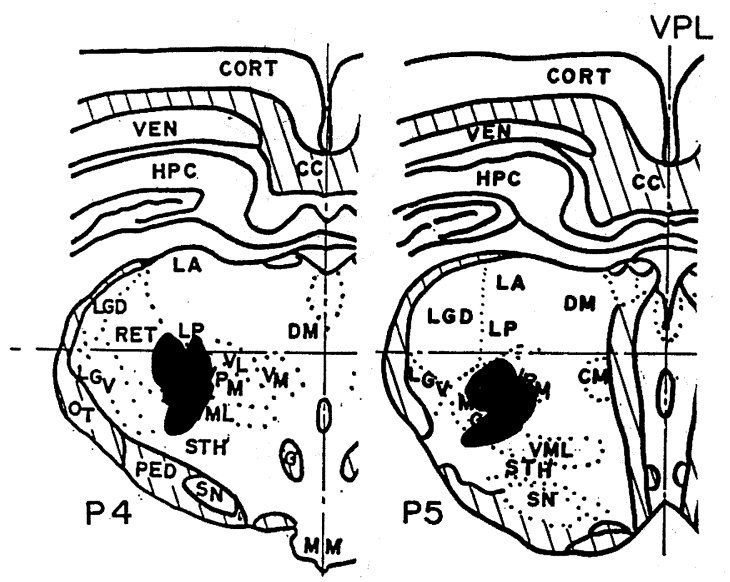

第52図 VPL の破壞部位

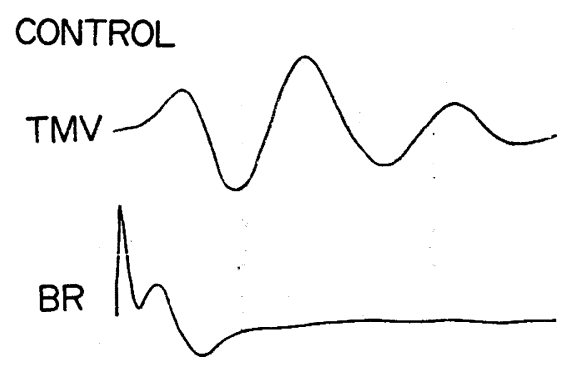

\section{VL LESION}

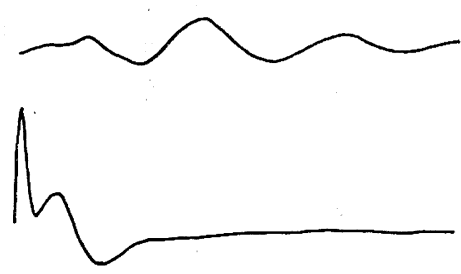

$2 \overline{\mathrm{Omsec}}$

第53図 TMV および BR に対する VL 破壊の影響

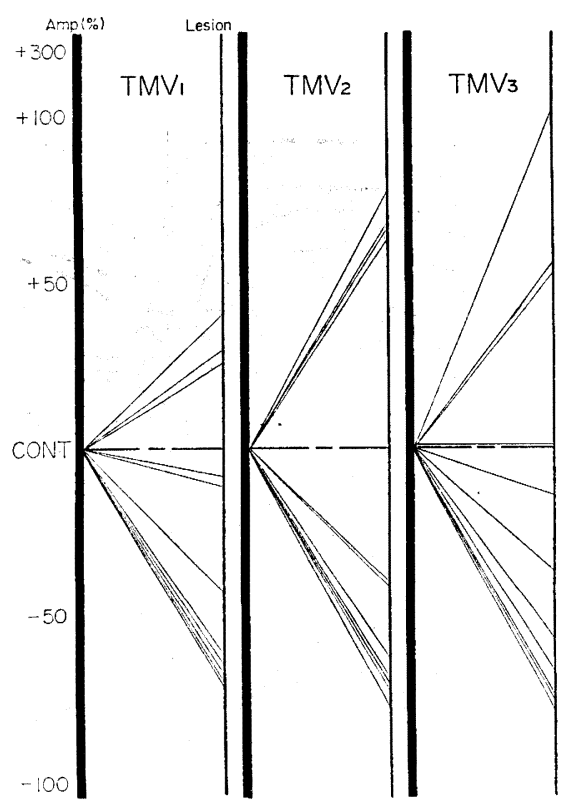

第54図 TMV の各 component 振巾のVL 破壞による 変化率 


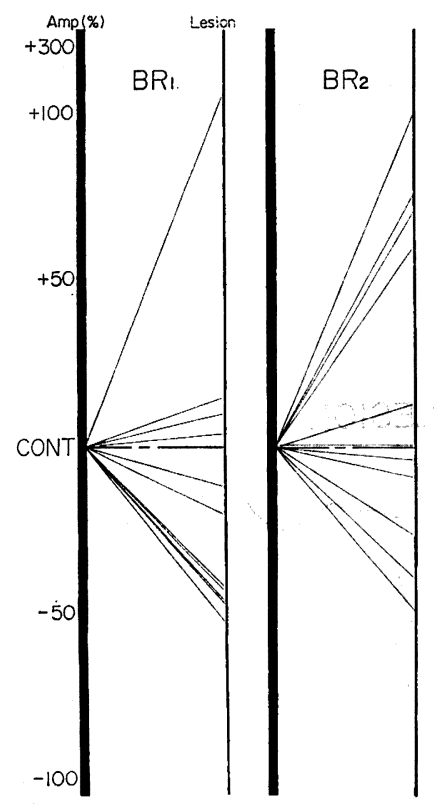

第55図 BR の各 component 振巾の VL 破壊による 変化率

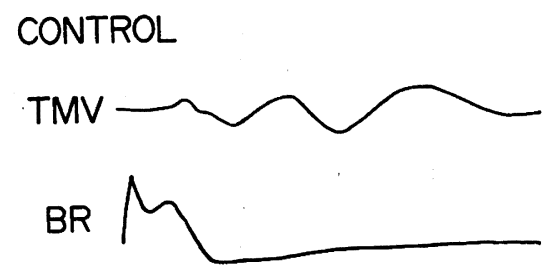

RET LESION

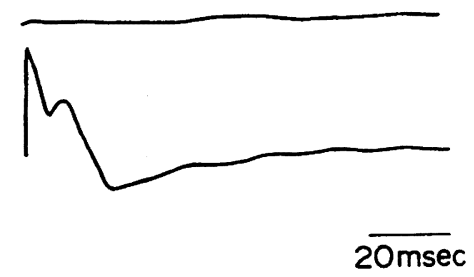

第57図 TMV および BR に対する RET 破壊の 影響

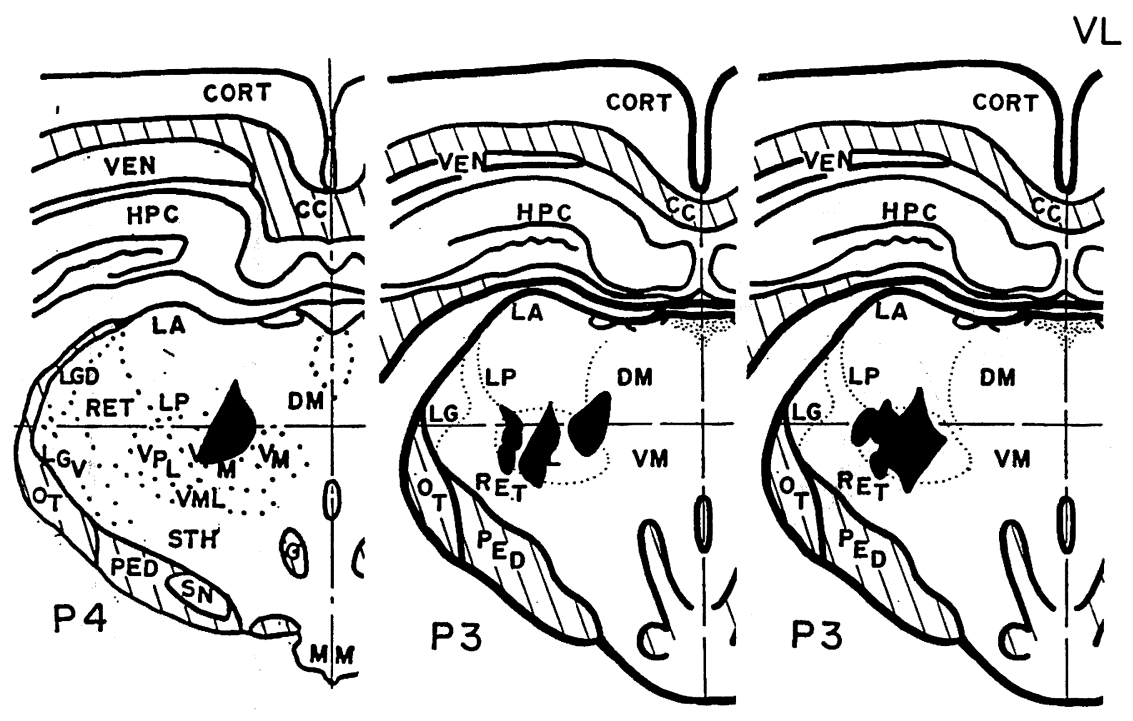

第56図 VL の破壞部位. 


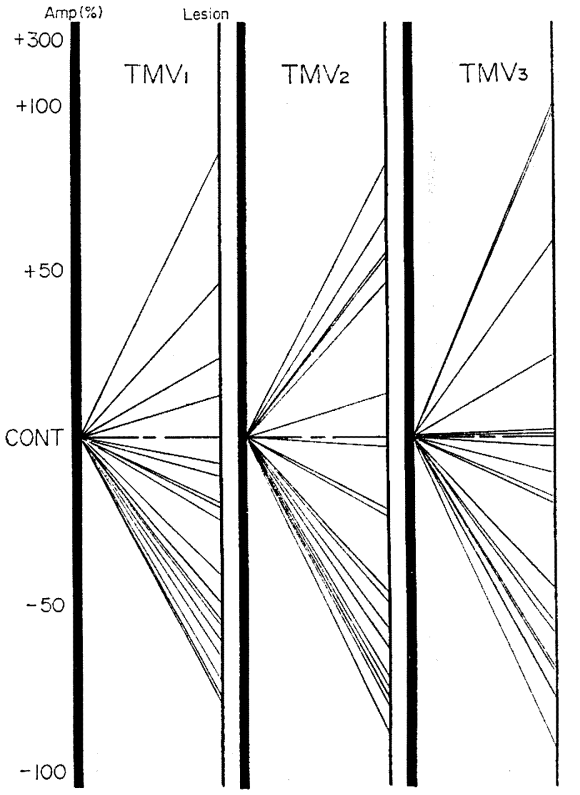

第58図 TMV の各 component 振巾の RET 破壊によ る変化率

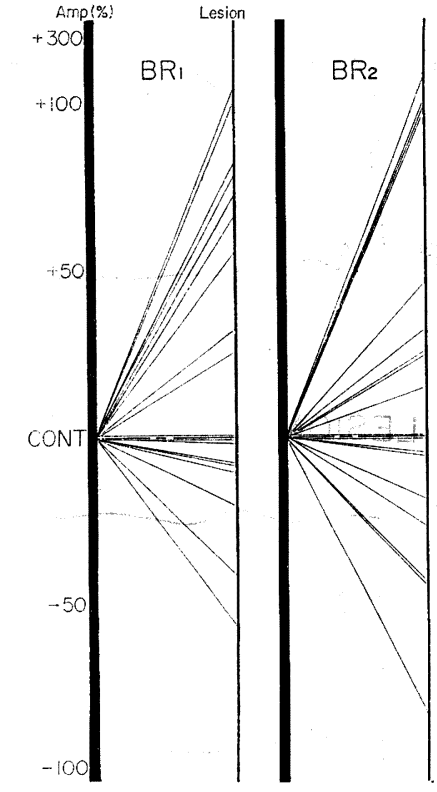

第59図 BR の各 component 振巾の RET 破壊による 変化率

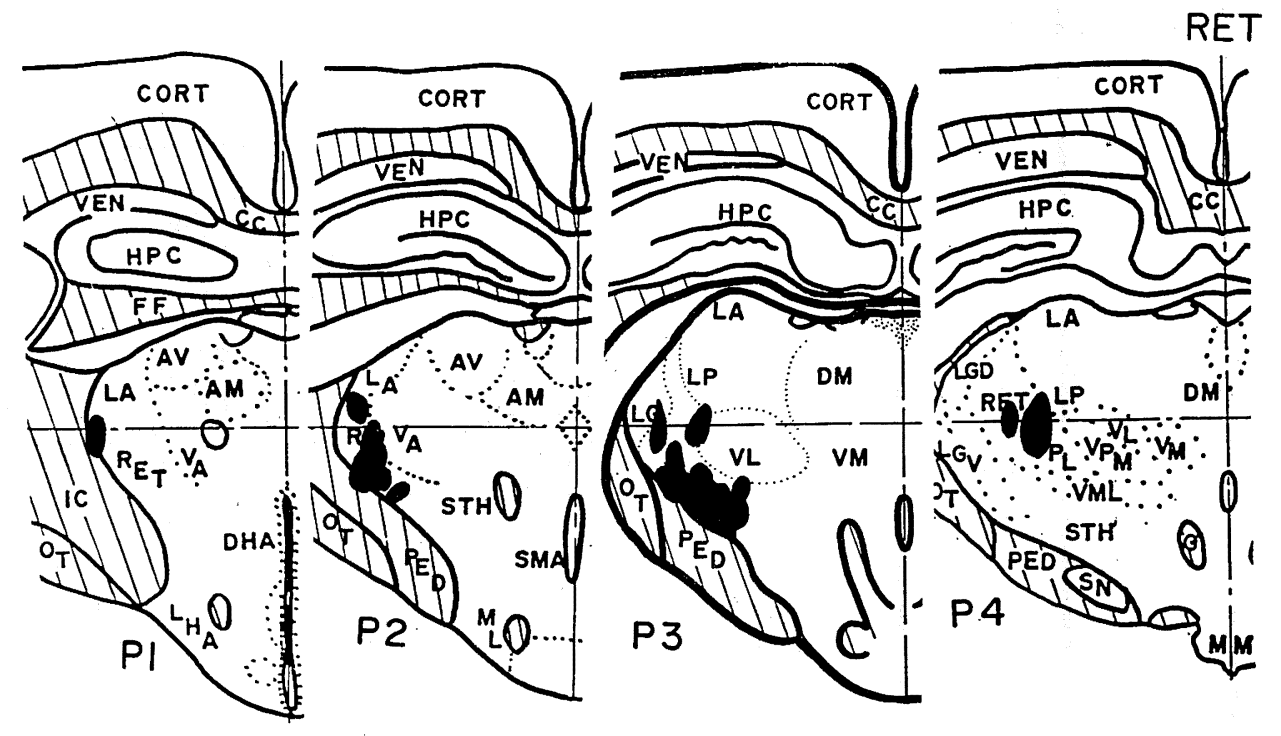

第60図 RET の破壞部位 
CONTROL

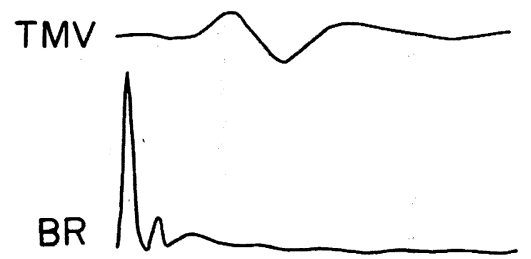

VML LESION

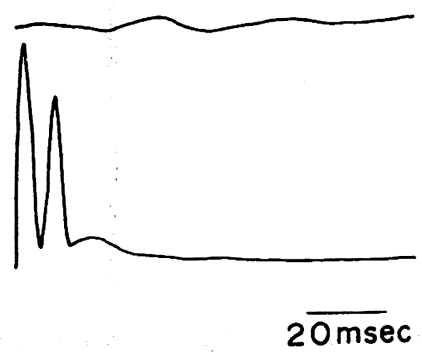

第61図 TMV および BR に対する VML 破壊の影響

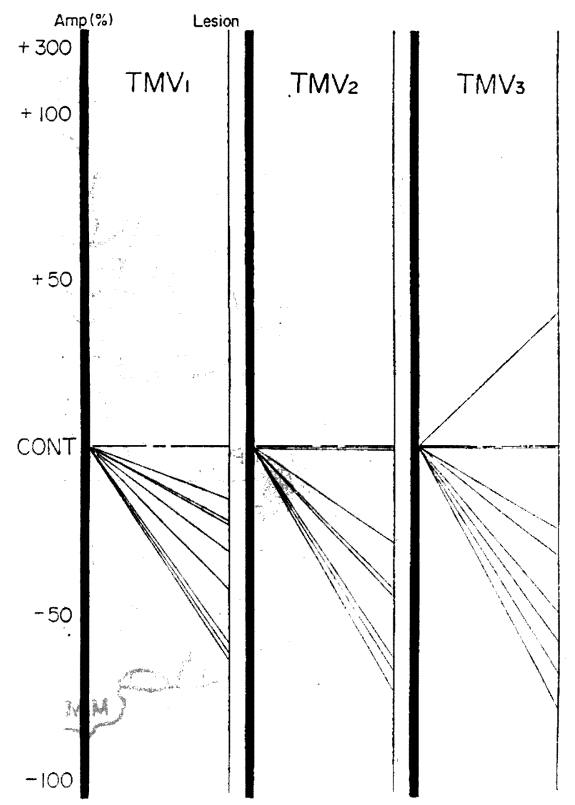

第62図 TMV の各 component 振巾の VML 破壊 による変化率

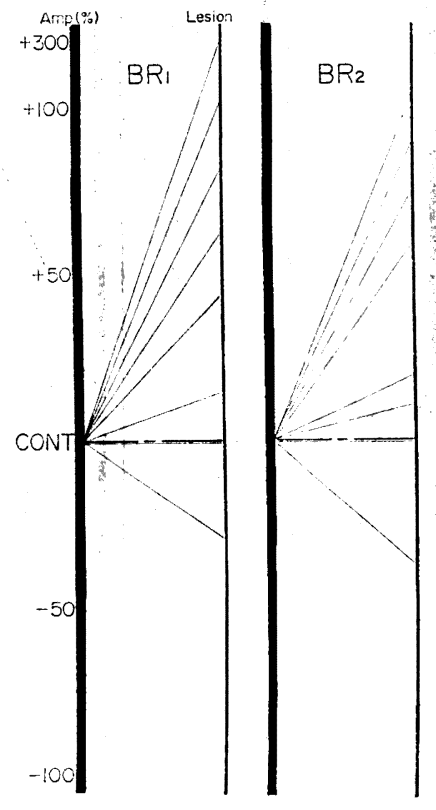

第63図 BR の各 component 振巾の VML 破壊 による変化率

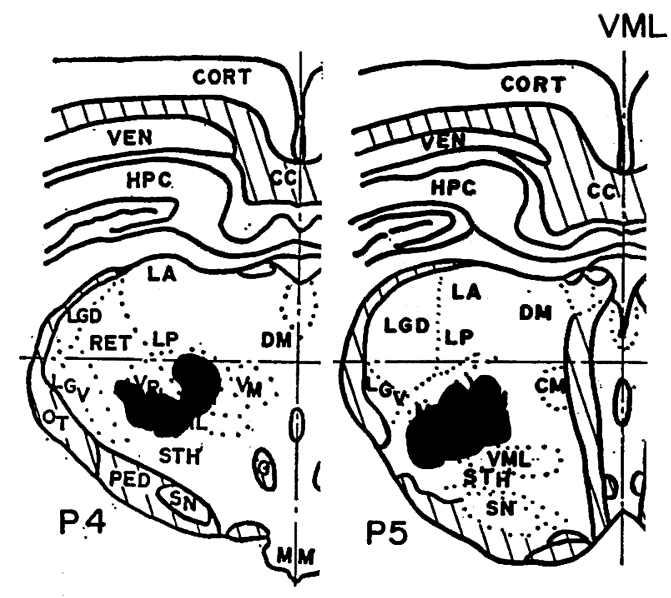

第64図 VML の破壊部位 
CONTROL

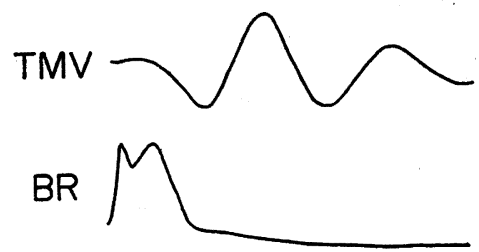

VA LESION

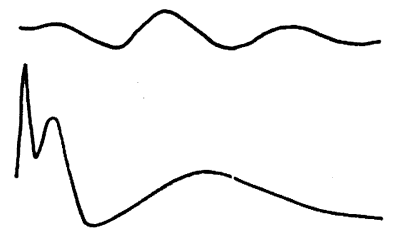

$\overline{20 \mathrm{msec}}$

第65図 TMV および BR に対する VA 破壊の影響

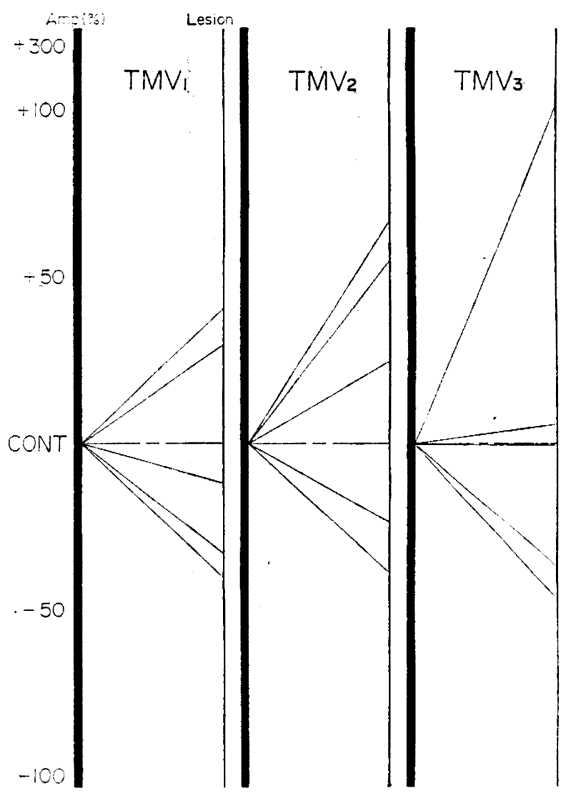

第66図 TMV の各 component 振巾の VA 破壊 による変化率

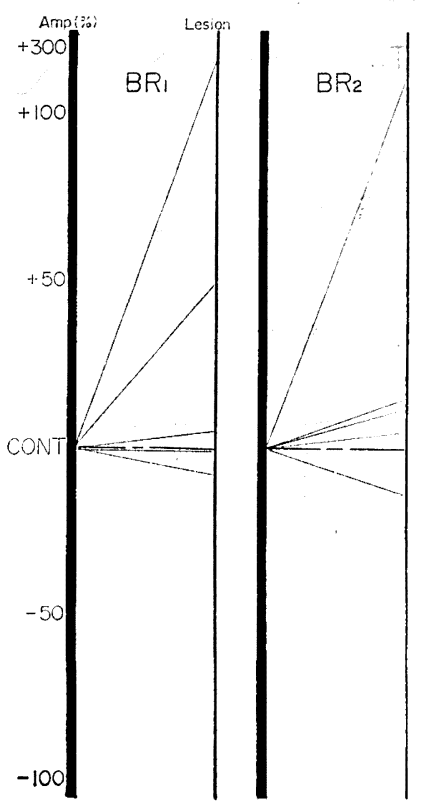

第67図 BR の各 component 振巾の VA 破壊 による変化率

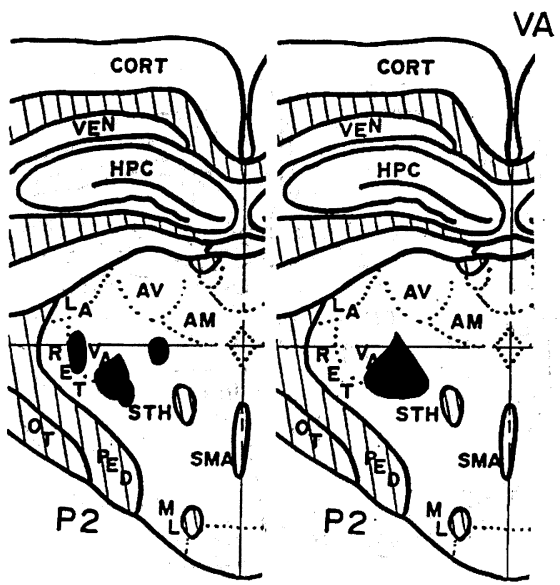

第68图 VA の破壊部位 


\section{CONTROL}

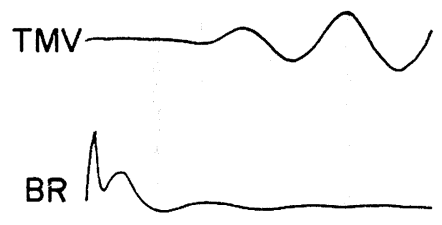

\section{LESION}

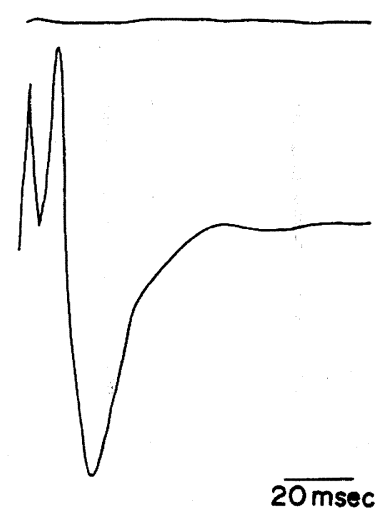

第69図 TMV および BR に対する $\mathrm{CM}$ 破壊の影響

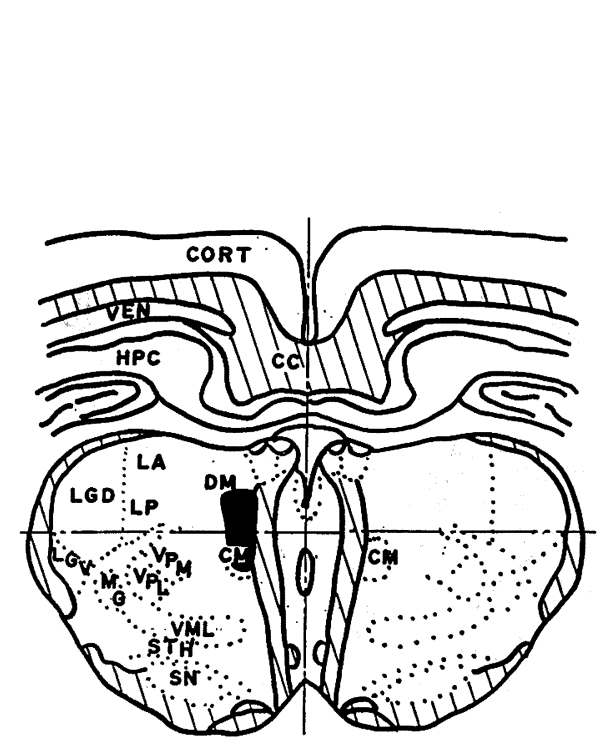

第70図 $\mathrm{CM}$ の破壊部位

\section{CONTROL}
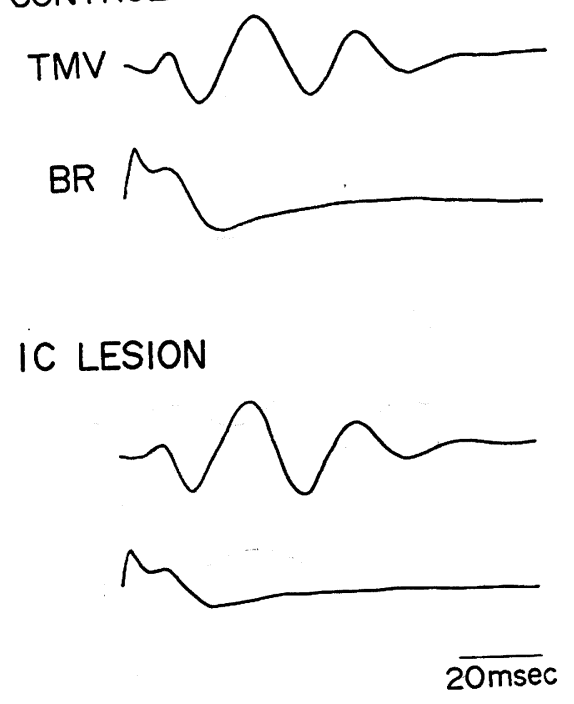

第71図 TMV および BR に対する IC 破壊の影響

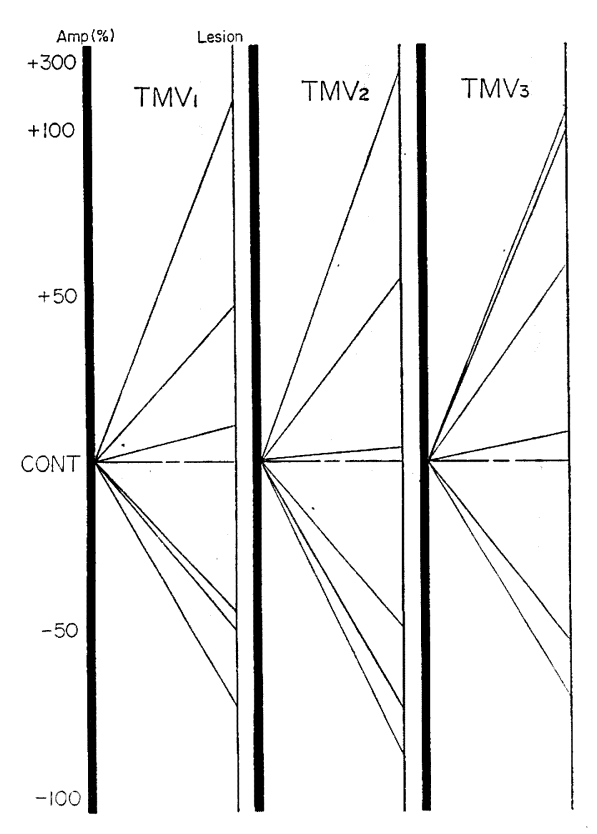

第72図 TMV の各 component 振巾の IC 破壊 による変化率 


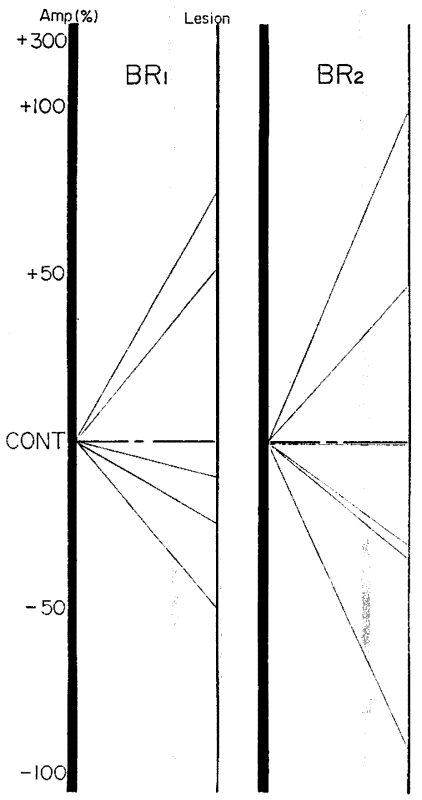

第73図 BR の各 component 振巾の IC 破壊 倿よる变化率
CONTROL

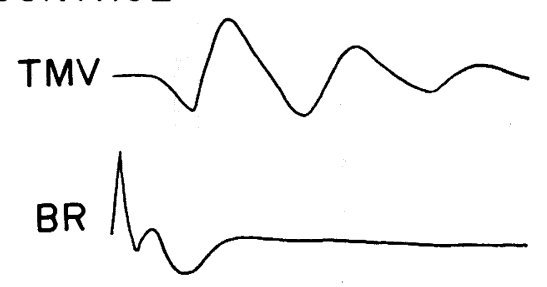

STH LESION

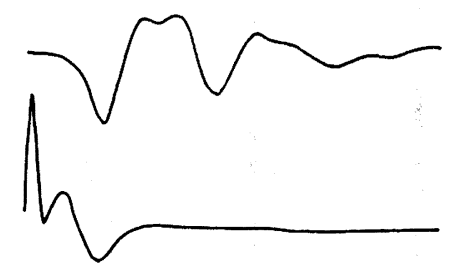

$\overline{20 \mathrm{msec}}$

第75図 TMV および BR に対する STH 破壊の影響

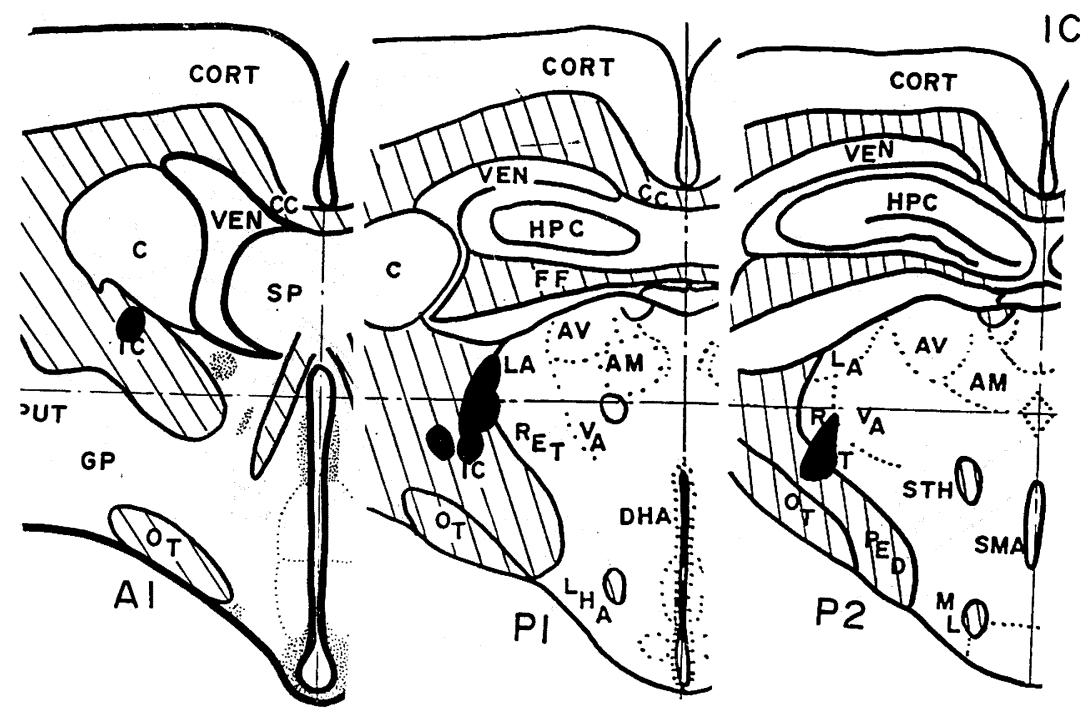

第74図 IC の破壊部位 


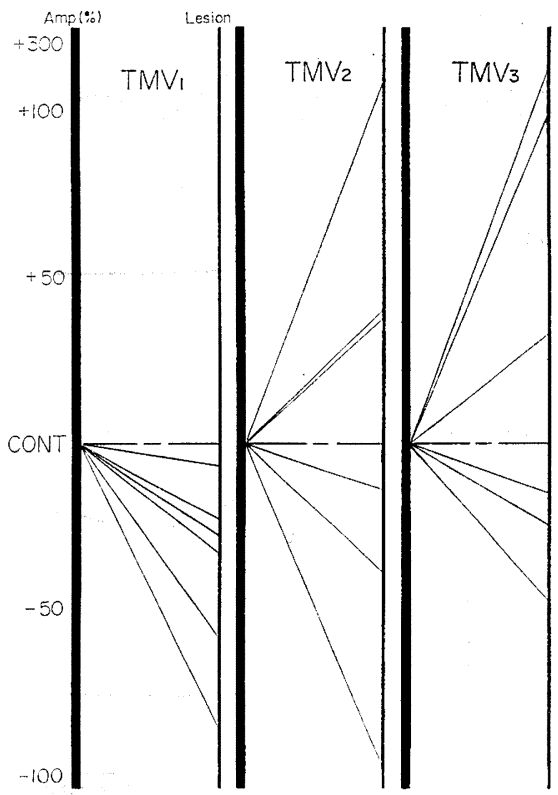

第76図 TMV の各 component 振巾の STH 破壊 による変化率

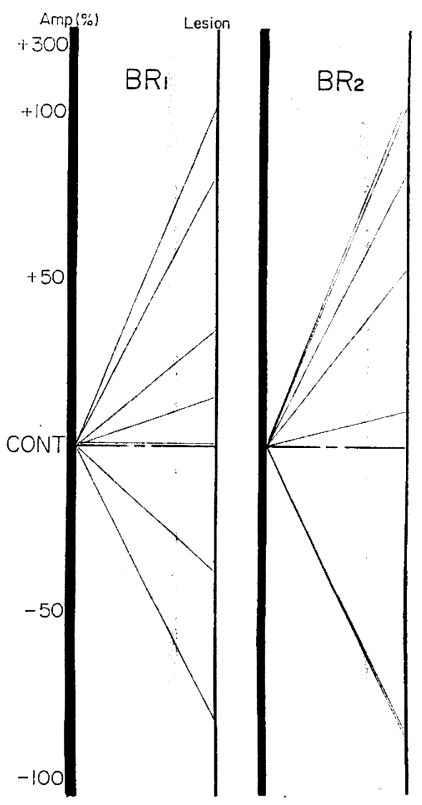

第77図 BR の各 component 振巾の STH 破壊 による変化率

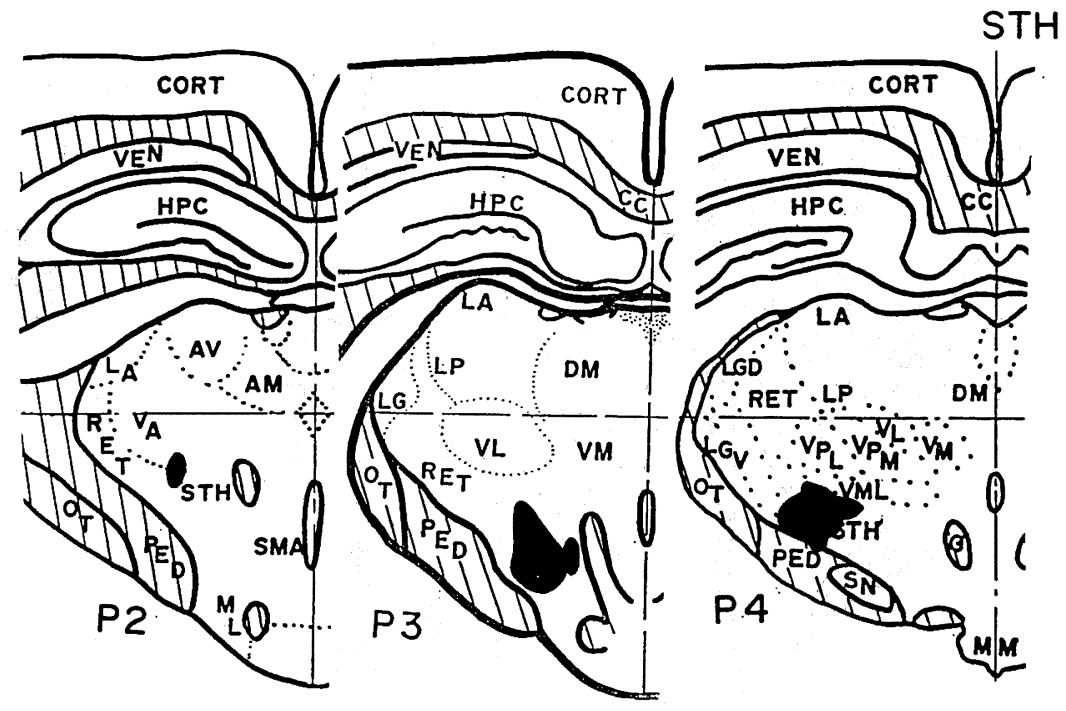

第78图 STH の破壊部位 


\section{CONTROL}

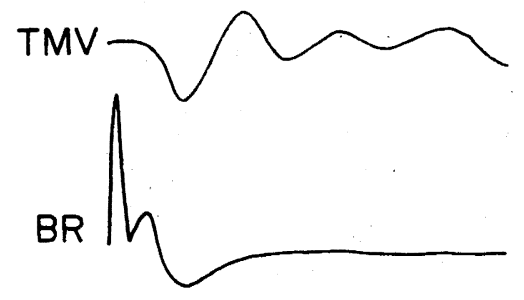

OT LESION

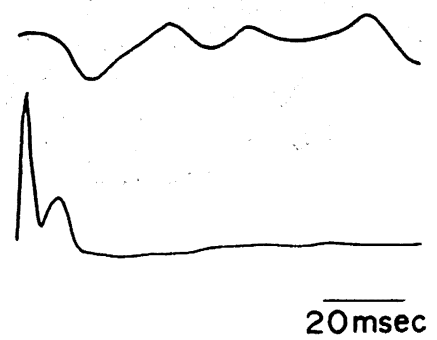

第79図 TMV および BR に対する OT 破壊の影響

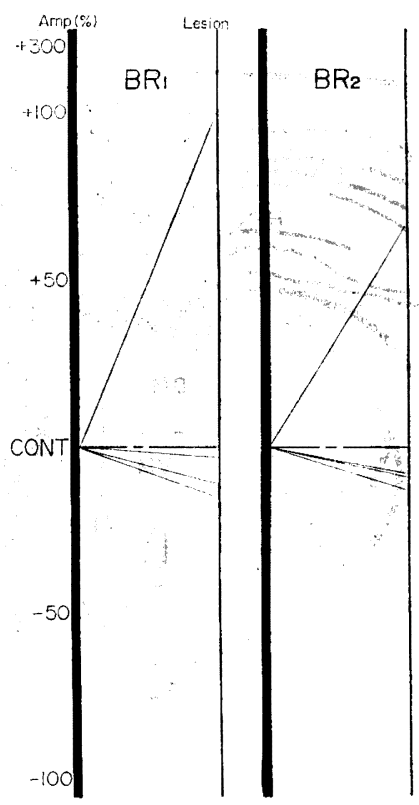

第81図 BR の各 component 振巾の OT 破壊 による変化率

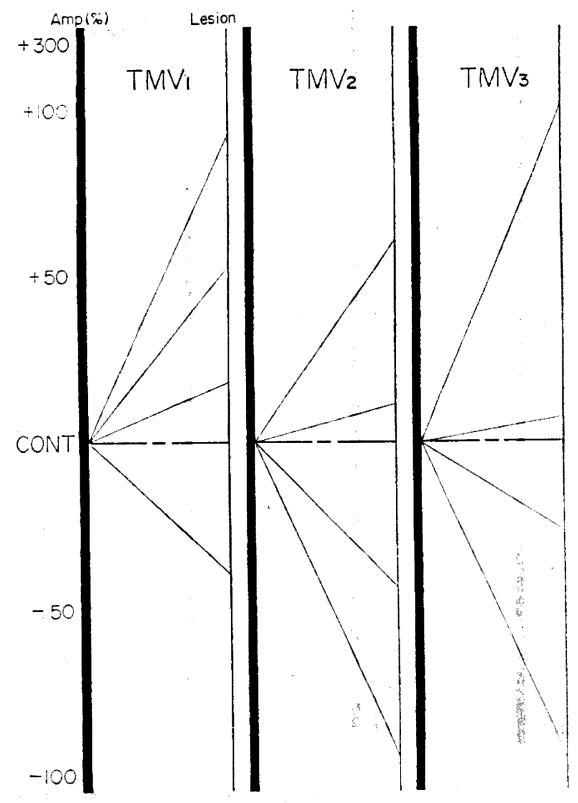

第80図 TMV の各 component 振巾の OT 破壊 による变化率
はほぼ完全に抑制され，BR は2例を除いて $\mathrm{BR}_{1}, \mathrm{BR}_{2}$ 共に振巾の増大をきたしている. 第90図は破壊部位の組 織図を示す。

13） III-nucl.（陻眼神経核）の破壤

動眼神経核は, 中脳上丘レベルにあり, 機能的には運 動と副交感神経系の節前線維を出す Edinger-Westphal 核よりなる，第91図はこの動眼神経核を破壊した時の TMV および BR への影響をみた実験例で, TMV は殆 ど消失し，BR は抑制が認められた。

第92図は, このような動眼神経核破壊例 5 例の TMV の各 component の振巾の变化率をまとめたもので, い ずれの component る約80 90\%の抑制が認められた. 第93図法, この際の $\mathrm{BR}$ の振巾の変化率をあらわし, 各 component 共平均45\%の抑制がみられた. これは TMV の変化に比して軽度であった. 第94図はこれら5例の動 眼神経核破壊部位を示す組織図である。

\section{4）まとめ}

以上視床核を中心として，その周辺および中脳網様 体，動眼神経核破壊の TMV および BR の各 component 振巾に及ぼす影響を一覧表にしたのが第 $6 ， 7$ 表であ 


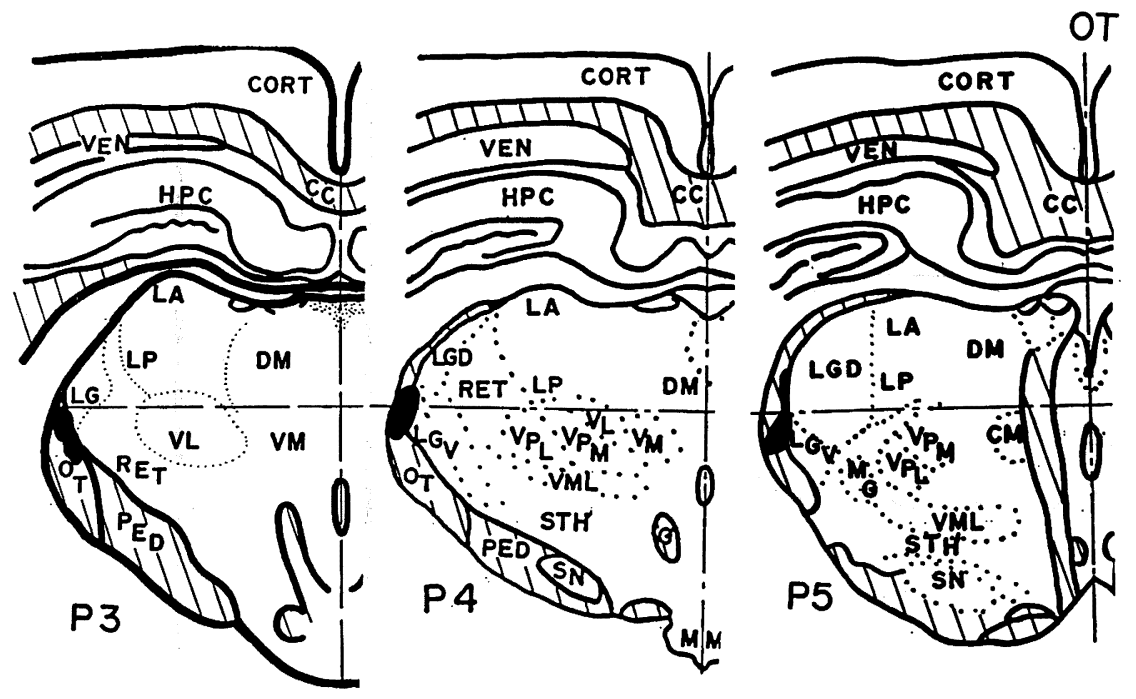

第82図 OT の破壊部位

CONTROL
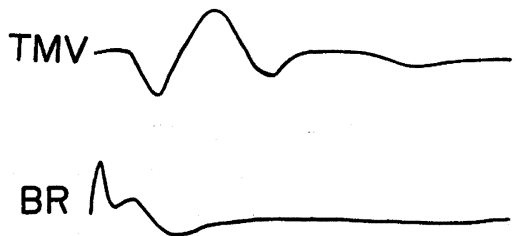

\section{LP LESION}

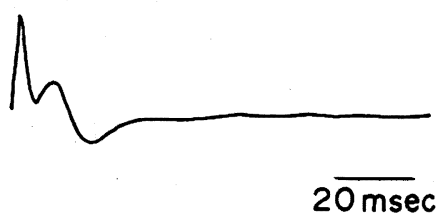

第83図 TMV および BR に対する LP 破壊の影響

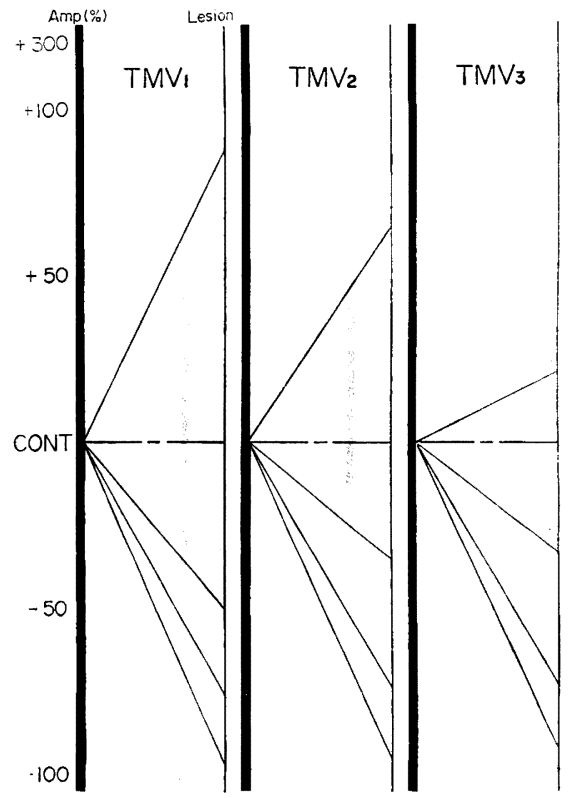

第84図 TMV の各 component 振巾の LP 破壊 による変化萃 


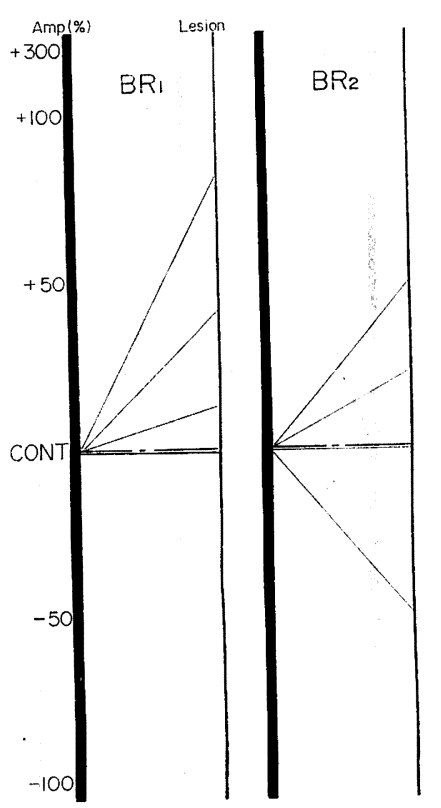

第85図 BR の各 component の LP 破壊による 变化率

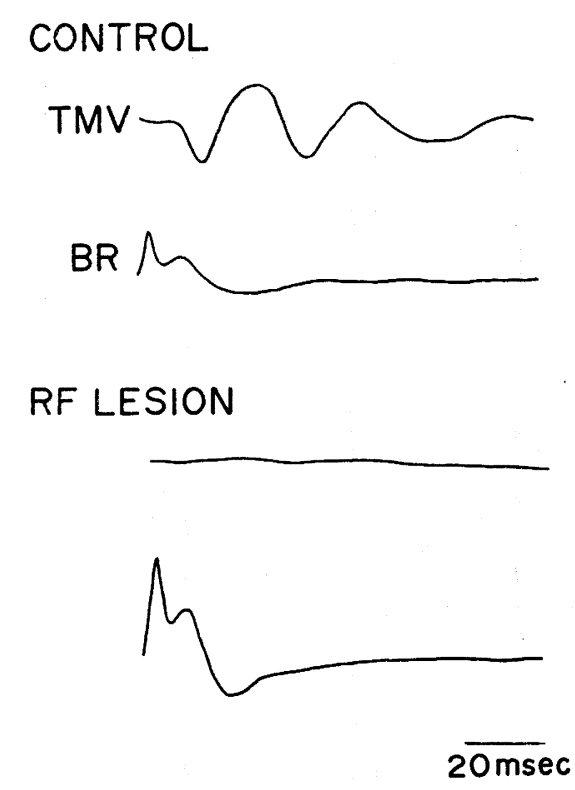

第87図 TMV および $\mathrm{BR}$ に対する RF 破壊の影響

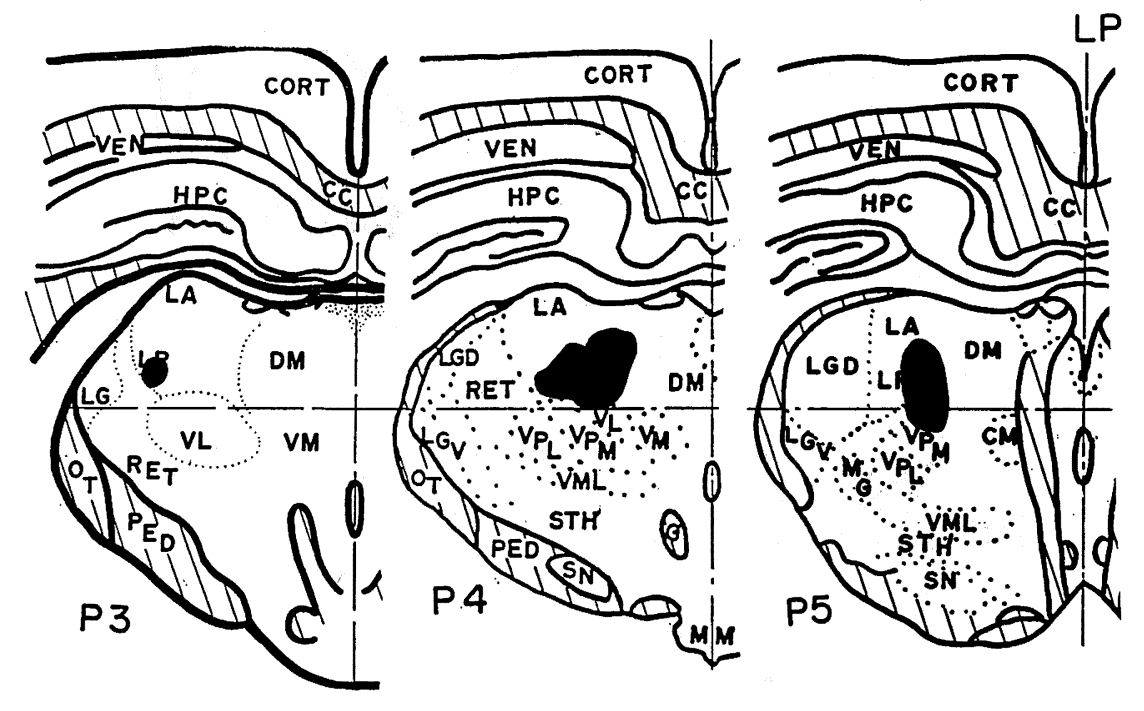

第86図 LP の破壊部位 


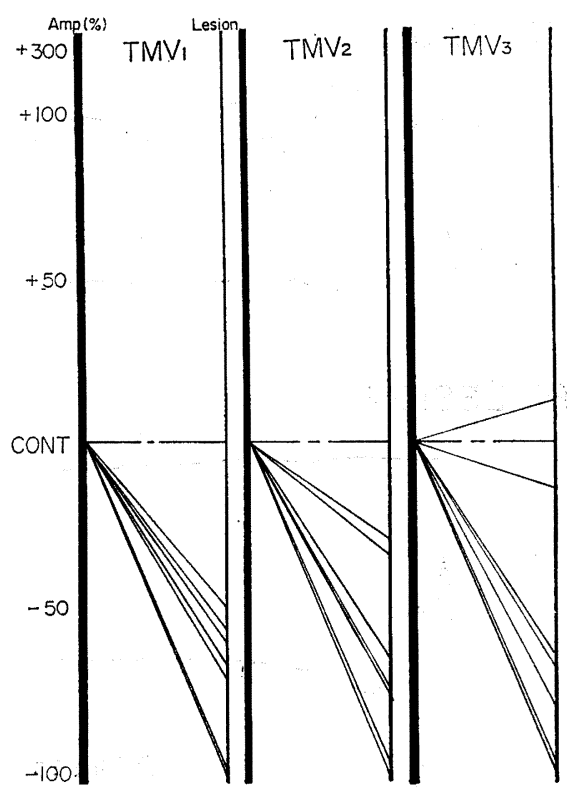

第88図 TMV の各 component 振巾の RF 破壊 による変化率

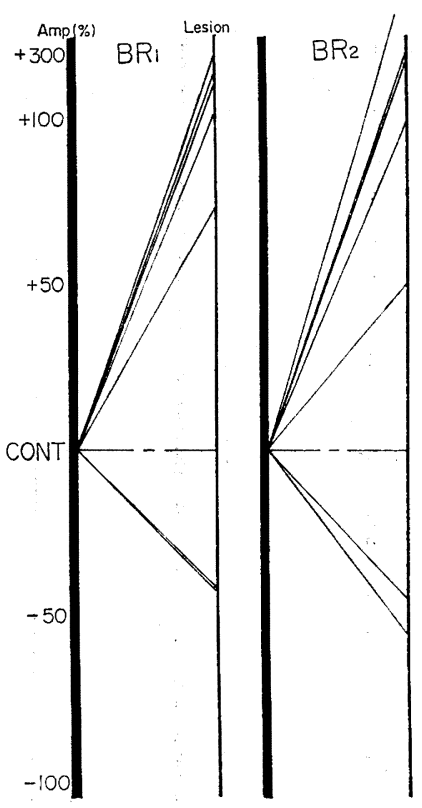

第89図 BR の各 component 振巾のR F 破壊 による変化率

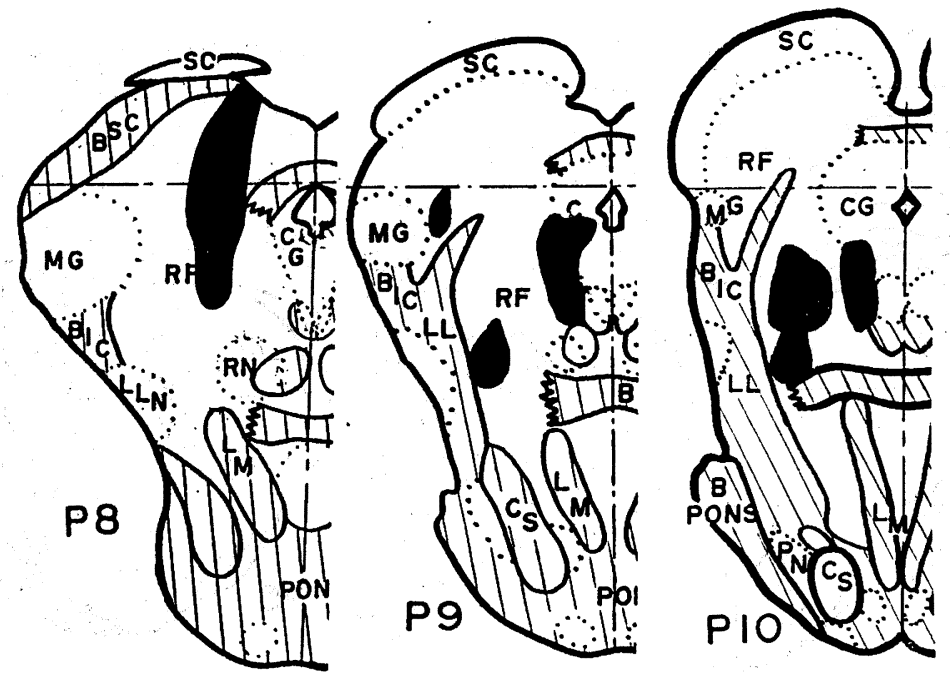

第90図 RF の破壊部位 
CONTROL

TMV

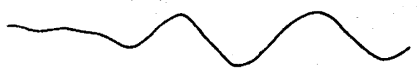
BR<smiles>CCCC1CC1</smiles>

III NuCl. LESION

\section{0 msec}

第91図 TMV および BR に対する III-nucl. 破壊の影響

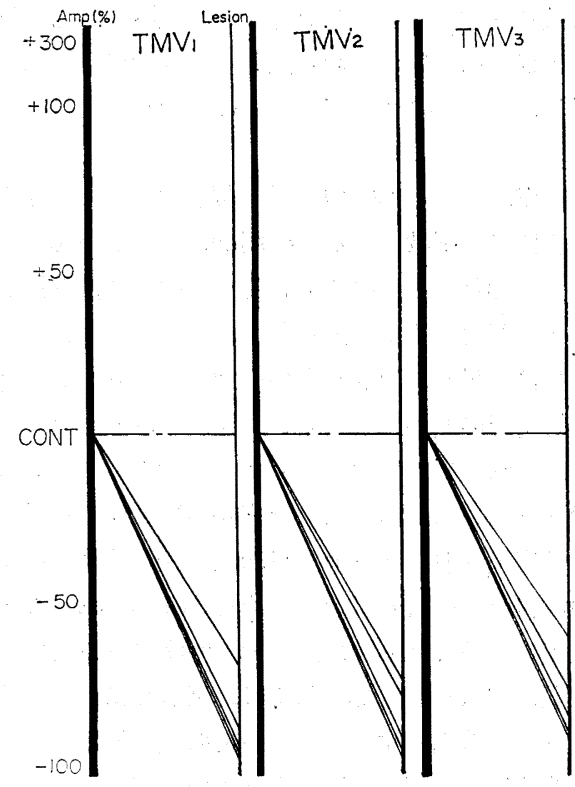

第92図 TMV の各 component 振巾の III-núcl. 破壊による变化率

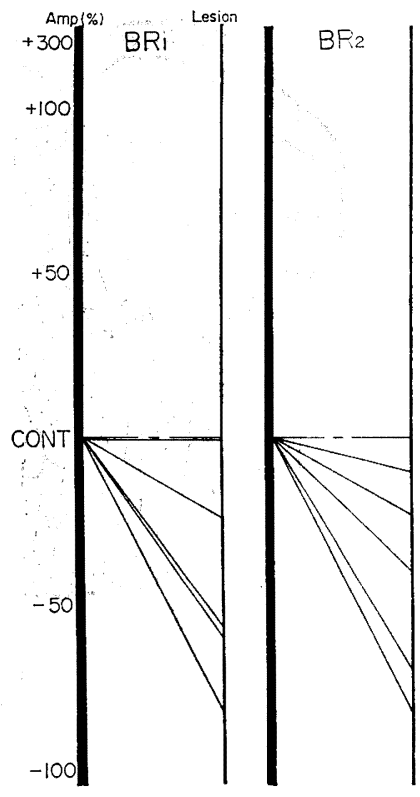

第93図 BR の各 component 振巾のIII-nucl. 破壊による变化率

る.ここでは破壊前值に比して破壊後の振巾の变化率が $\pm 10 \%$ 以内のものは，すべて不変（一）として报い， 10 \%を超えるむのを正 ( $\uparrow$ ）の方向, $-10 \%$ よりも抑制の 強かったものを負 (】) の方向として分類した.

これによると, TMV の各 component 振巾の抑制をき たす破壊部位は, VPM, VPL, VL, RET, VML と中脳 網様体および動眼神経核であった. BR については，各 component 振巾の増大を来す破壊部位は，VPM，VPL， RET, VML, STH と中脳網様体であった。また BRの 各 component 振巾の減少を来寸破壊部位は, 動眼神経 核のみであった。

\section{MV と SNR}

\section{考察}

人の身体表面には生理的に存在する微小振動が認めら れ，一般に Microvibration(MV) と呼ばれている.MV についての研究は, Rohracher ${ }^{5)}$ が報告して以来, 数多 くの研究者によって, その発現機序の検討がなされてき たが，この微小振動は心拍に由来する低周波帯域の成分 と，骨格筋に由来する高周波帯域の成分からなるものと 解されている14)15). 


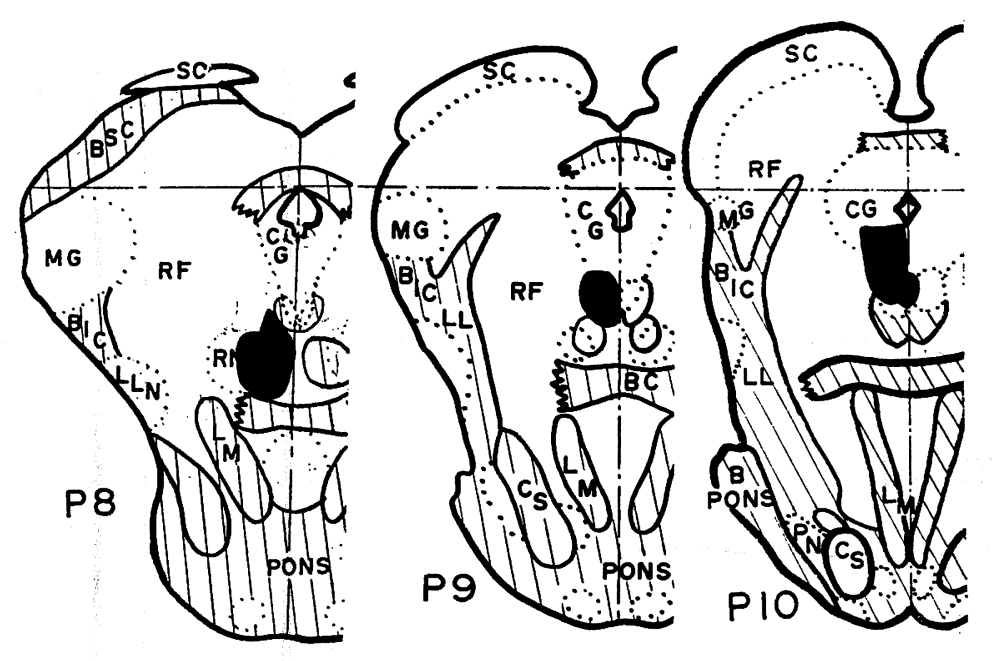

第94図 III-nucl. の破壊部位

しかしながら上眼䀫に認められる MV 法，体表面の それとはかなり趣を異にし, 単に眼輪筋そのものに由来 するだけでなく，脳幹網様体の㗢きとも密接に関係して いることが明らかにされてきた。すなわち, 稲永ら尾猗 ら6) 15-18) は, ヒトにおける光眼輪筋反射 (photopalpebral reflex, PPR) とMVについて記録し，それぞれ 諸種薬物の影響, 睡眠時の影響, 精神疾患とのかかわり や, 網膜電位 (ERG) との関係等について研究した.

またウサギを用いた実験では, 当教室の丸尾, 大友ら の研究があり, 丸尾は19) 眼䀫部より双極導出した電位 を対象とした実験で視神経切断の影響, 薬物の作用につ いて実験を行い, PPR には眼球に由来するものと中枢 神経を介する電位があることを明らかにし，大友は20) 眼䀫部よりの単極導出実験で, 網膜電位に関係する成分 と脳幹部を介する成分のあることを報告した。 また西浦 7) は, MV と PPR の同時記録を行い, また脳幹網様体 からの unit discharge を導出する研究を行った結果, MV の発現には脳幹網様体が直接関係し, 大脳皮質や海 馬は間接的な影響を及ぼすこと，したがって MV を観 察することにより, 脳幹網様体の機能の表現である意識 状態を知ることができるばかりでなく，高次の精神活動 や情動面における活動の变化をる知りうるとしている. 服部8) は, PPR, ERG，MV および視覚誘発反応 (visual evoked response, VER) を記録し、ウサギにお ける PPR には, ERG 成分である early component と, 中枢を介して発現する late component が存在し，
この late component の発現には, 脳幹部の神経組織 の activity が関与することを明らかにした。

山田9) 10), 安原 21-25) らは, 聴覚刺激による MVの 反応，あるい汇閃光刺激による MV の反応関する実 験から，MV の中脳網様体との関係を主張している.

また山本11）注，閃光刺激により上眼䀫に誘発される MV に及ぼす皮質下核(尾状核, 被殼, 淡蒼球, 扁桃核, 海馬および視床 VL 核）の刺激および破壞の影響につい て検討し，MV は錐体外路系からの影響を無視できない とした。

さて皮庴，筋，深部組織などを傷害するような刺激 は，一般に侵害刺激（noxious stimulus）と呼えでいる が, これが加わると反射的に屈筋を収縮させ, 関節が屈 曲し，からだを縮めて刺激から逃げるような動作がおこ る. これは反射性に屈筋支配の運動ニューロンが促進さ れ，伸筋支配の運動ニューロンが抑制されるためとされ ている.これを屈曲反射 (flexion reflex)，あるいは屈 筋反射 (flexor reflex), また傷害から逃避する行動でも あるので逃避反射 (escape reflex), 防衛反射 (defence reflex), 侵害 (受容) 反射 (nociceptive reflex) などと 呼ばれている26)，例えばウサギの坐骨神経の枝である 脛骨神経に電気刺激を加えた時に，反射性に前脛骨筋に 誘発される筋放電，すなわち侵害反射性筋放電は, 神経 生理学的研究にしばしば利用されている27.

今回, 私が行った実験はウサギの坐骨神経汇電気刺激 を加えた場合, 同側の上眼䀫に誘発される眼䀫筋の収縮 
第 6 表 中枢破壊の TMV 各 component $飞$ 及ぼす影響

\begin{tabular}{|c|c|c|c|c|}
\hline \multicolumn{2}{|c|}{ Site of Lesion } & TMVI & TMV2 & $\mathrm{TMV}_{3}$ \\
\hline \multirow{3}{*}{ VPM } & $\uparrow$ & 1 & 2 & 1 \\
\hline & - & 2 & 0 & 0 \\
\hline & $\downarrow$ & 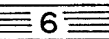 & $\equiv 7 \equiv$ & $E 8 \equiv$ \\
\hline \multirow{3}{*}{ VPL } & $\uparrow$ & 0 & 1 & 2 \\
\hline & - & 1 & 1 & 1 \\
\hline & $\downarrow$ & ( $7 \equiv$ & 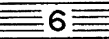 & $\equiv 5 \equiv$ \\
\hline \multirow{3}{*}{ VL } & $\uparrow$ & 3 & 4 & 3 \\
\hline & - & 1 & 0 & 1 \\
\hline & $\downarrow$ & $\bar{E} \bar{\equiv}$ & $\equiv 7 \equiv$ & 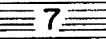 \\
\hline \multirow{3}{*}{ RET } & $\uparrow$ & 4 & 6 & 4 \\
\hline & - & 1 & 1 & 4 \\
\hline & $\downarrow$ & 默13” & $\equiv 11 \equiv$ & 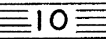 \\
\hline \multirow{3}{*}{ VML } & $\uparrow$ & 0 & 0 & 1 \\
\hline & - & 0 & 2 & 1 \\
\hline & $\downarrow$ & $8 \equiv$ & $6 \equiv$ & $\equiv 6 \equiv$ \\
\hline \multirow{3}{*}{ VA } & $\uparrow$ & 2 & 3 & 1 \\
\hline & - & 0 & 0 & 2 \\
\hline & $\downarrow$ & 3 & 2 & 2 \\
\hline \multirow{3}{*}{$1 C$} & $\uparrow$ & 3 & 2 & 3 \\
\hline & - & 0 & 1 & 1 \\
\hline & $\downarrow$ & 3 & 3 & 2 \\
\hline \multirow{3}{*}{ STH } & $\uparrow$ & 0 & 3 & 3 \\
\hline & - & 2 & 2 & 1 \\
\hline & $\downarrow$ & 5 & 2 & 3 \\
\hline \multirow{3}{*}{ OT } & $\uparrow$ & 2 & 2 & 1 \\
\hline & - & 0 & 0 & 1 \\
\hline & $\downarrow$ & 2 & 2 & 2 \\
\hline \multirow{3}{*}{ LP } & $\uparrow$ & 1 & $T$ & 1 \\
\hline & - & 0 & 0 & 0 \\
\hline & $\downarrow$ & 3 & 倞 & 3 \\
\hline \multirow{3}{*}{ RF } & $\uparrow$ & 0 & 0 & 1 \\
\hline & - & 0 & 0 & 0 \\
\hline & $\downarrow$ & 至 $7 \equiv$ & 至7严 & 昰6至 \\
\hline \multirow{3}{*}{ III Nucl. } & $\uparrow$ & 0 & 0 & 0 \\
\hline & - & 0 & 0 & 0 \\
\hline & $\downarrow$ & 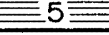 & $5 \equiv$ & $5 \equiv$ \\
\hline
\end{tabular}

反応を，MV 用 transducer により加速度变化としてと らえ，電位変化に変換し，これを digital computerによ り平均加算して得られた波形, すなわち SMV の神経生 理学的意義を解明するために，同時に同側下肢前脛骨筋 亿誘発される侵害反射性筋放電 SNR を測定し, さらに SMV と SNR との関係について検討を加えた. またこ の際，種々の中枢作用薬を負荷した場合の SMV およ びSNR に対する影響を観察した。

坐骨神経を電気刺激した場合に，上眼䀫に誘発される
SMV については，既に当教室の立花が報告し， sciaticevoked eyelid microvibration すなわち SMVと命名して いる. 立花は13)，SMVは 3 つの component から構成さ

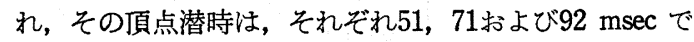
あるとした。 そして，これらの各 component に及ぼす Morphine および Procaine の作用と，VPM，VPL，VA， $\mathrm{CM}$ など視床核の破壞実験を行っている. その結果, SMV の $3 つ の$ component $は$, Morphine の静注と Procaine の末梢神経塗布により, 薬物の投与量に相関し て強く抑制されたと報告している。 また視床核破壊実験 では, VPM, VPL, CM の破壊によって SMV の各 component の振巾は抑制され，VA の破壊ではSMV の 振巾は増大を示した。 また視床核以外に, 中脳網様体 および動眼神経核の破壊実験を行ったところ，VPM， VPL, CM 破壊時より強い抑制の成績が得られ，SMV の発現には VPM, VPL, CM, 中脳網様体, 動眼神経 核などの神経組織が，直接あるいは間接に関与している と指摘している.

今回, SMV と SNR の神経生理学的, 薬理学的検討 を行う前に，基礎的検討として，1）上眼䀫 SMV の波 形と SMV の各 component の頂点潜時および，2）前脛 骨筋に誘発される侵害反射性筋放電 SNR と, その頂点 潜時の検討, ついで 3 ) 電気刺激反復時の SMV およ び SNR の頂点潜時と振巾について, いわゆる「慣れ」 (habituation) について子観察した. さらに4) 刺激部 位の左右差による SMV および SNR の波形についても 検討を加えた。 その結果, SMV については, 立花の報 告と同様の頂点潜時を持つ $3 つ$ component が得られ た. 今回新たに行った電気刺激反復時の SMV および SNR の頂点潜時は, 刺激を反復していくと, SMV では 若干延びる傾向が，一方 SNR は短縮する傾向がみられ たが，統計学的には有意ではなかった．またこれらの振 巾の変化は，いわゆる「慣れ」の現象がみられたが， SNR の方がSMV に比して変動は小さい様に思われた. 次に，導出すべき SMV 汢上眼䀫に固定し，右坐骨神経 刺激時と, 左坐骨神経刺激時で SMV の各 component の 頂点潜時に差がないかどうかについて検討した結果, 統 計学的には有意ではないが, $\mathrm{SMV}_{1}$ と $\mathrm{SMV}_{2}$ の成分 では同側に比して反対側刺激時の頂点潜時は若干延びる 傾向があるのに対して, $\mathrm{SMV}_{3}$ では逆に短縮する傾向が 伺われた.

以上，本実験に打ける基礎的事項を調らべた上で， 諸種中枢作用薬を負荷し，その反応態度から SMVの各 component および SNR の由来, 両者の関係などについ て推定を試みた。 
第 7 表 中枢破壊の BR 各 component K及ぼす影響

\begin{tabular}{|c|c|c|c|c|c|c|c|}
\hline \multicolumn{2}{|c|}{ Site of Lesion } & BRI & BR2 & \multicolumn{2}{|c|}{ Site of Lesion } & BRI & BR2 \\
\hline \multirow{3}{*}{ VPM } & $\uparrow$ & Iillin, & 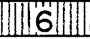 & \multirow{3}{*}{ IC } & $\uparrow$ & 2 & 2 \\
\hline & - & 2 & 1 & & - & 0 & 1 \\
\hline & $\downarrow$ & 2 & 2 & & $\downarrow$ & 4 & 3 \\
\hline \multirow{3}{*}{ VPL } & $\uparrow$ & 4 & 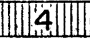 & \multirow{3}{*}{ STH } & $\uparrow$. & 4 & 15 \\
\hline & - & 3 & 3 & & - & 1 & 0 \\
\hline & $\downarrow$ & 1 & 1 & & $\downarrow$ & 2 & 2 \\
\hline \multirow{3}{*}{ VL } & $\uparrow$ & 5 & 5 & \multirow{3}{*}{ OT } & $\uparrow$ & 1 & 1 \\
\hline & - & 2 & 3 & & - & 1 & 1 \\
\hline & $\downarrow$ & 4 & 3 & & $\downarrow$ & 2 & 2 \\
\hline \multirow{3}{*}{ RET } & $\uparrow$ & |9|| & [10] & \multirow{3}{*}{ LP } & $\uparrow$ & 2 & |2] \\
\hline & - & 4 & 4 & & - & 1 & 1 \\
\hline & $\downarrow$ & 5 & 4 & & $\downarrow$ & 1 & 1 \\
\hline \multirow{3}{*}{ VML } & $\uparrow$ & 6 & 6 & \multirow{3}{*}{ RF } & $\uparrow$ & 5 & 15 \\
\hline & - & 1 & 1 & & - & 0 & 0 \\
\hline & $\downarrow$ & 1 & 1 & & $\downarrow$ & 2 & 2 \\
\hline \multirow{3}{*}{ VA } & $\uparrow$ & |IIIIIIII & 3 & \multirow{3}{*}{ IIINucl. } & $\uparrow$ & 0 & 0 \\
\hline & - & 3 & 1 & & - & 1 & 1 \\
\hline & $\downarrow$ & 0 & 1 & & $\downarrow$ & 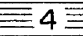 & $4 \equiv$ \\
\hline
\end{tabular}

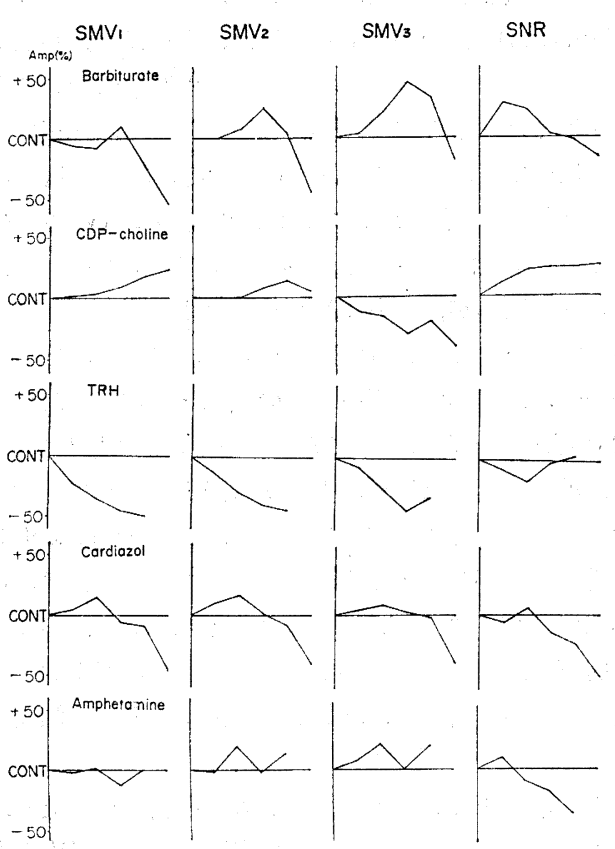

第95図 SMV および SNR の各種中枢作用薬 による影響の比較
ここで，諸種薬物の反応態度についての理解を容易に するために, 対照 $\left(\mathrm{H}_{2} \mathrm{O}\right)$ の変動との比較を第95図に表 わした．すなわち，この図では諸種薬物負荷時の振巾の 変化率の値加, 対照 $\left(\mathrm{H}_{2} \mathrm{O}\right)$ の振巾の変化率の值を差 引き, 対照を基線としての変化として表現した.

まず Barbiturate の場合には, SMVの $3 つ$ component 間に反応に相異がみられ, $\mathrm{SMV}_{1}$ では少量では変 動は殆どなく, $10 \mathrm{mg} / \mathrm{kg}$ 以上で強い抑制がみられるのに

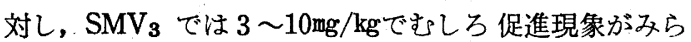
れ，20mg/kgでようやく抑制された。一方，SNR は， Barbiturate の少量で興奮し, $5 \mathrm{mg} / \mathrm{kg}$ 以上でこの効果は 減衰し, $\mathrm{SMV}_{3}$ と同じく $20 \mathrm{mg} / \mathrm{kg}$ で抑制された. $\mathrm{SMV}$ と SNR の Barbiturate に対する反応態度について, 両者 の相関をとってみると, $\mathrm{SMV}_{2}$ と SNR とは逆相関の 関俰侄あったが統計学的には有意ではなかった。なお， SMV の各成分は，本剂に対する sensitivity は異るる のの平行した変動を示した. このことは, 坐骨神経刺激 による impulse の反射経路において脳幹網様体とは別の 何らかの中枢神経組織の存在が示唆される ${ }^{28)}$. Barbiturate：は，あらゆる組織の細胞機能を可逆的に抑制する が，同一用量または同一濃度ですべての組織が抑制され るのではないとされている. 中枢神経系が最も鋭敏であ りしたがって鎮静または催眠量の Barbiturate では骨 格筋，心筋，平滑筋には殆ど影響しないといわれてい 
る. 従来本刘の作用部位は，脳幹性であるとされていた が, 大脳皮質にむ作用し，大量の場合は延㖪に対し

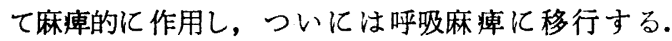

Barbiturate には，通常抗侵害刺激作用 (鎮痛作用) 流な く, 実際少量では Barbiturate は疼痛刺激化対する反応 を增強させる29)30) とされているが，本実験における SMV, SNR の成績においてもその傾向が見られた.

CDP-choline を投与した場合には, SMV に対しては, 投与量を増やすことによって第 1 と第 2 成分は軽度に振 巾の増大をきたすが, 第3成分はこれとは逆に，投与量に 比例して振巾の減少, すなわち抑制作用が認められた。 しかし, SNR に対しては常に促進的作用し， $3 \mathrm{mg} / \mathrm{kg}$ 以上では用量に関係なく一定の促進作用を示した。 CDP-choline は, 脳幹網様体賦活作用を有し, 意識の覚 醒を促するのであるが，この実験では SMV の第 1 成分 と SNR の興奮を促し, SMV の第 3 成分を抑制した. このことは, Barbiturate 投与時の SMV およびSNR の 反応態度と共に考えあわせると極めて興味深い事実であ る. 今回の実験成績よりみれば, SMV の第 1 ，第 2 の 成分は多分脳幹網様体とつながりがあり，また SNR む 直接的にあるい海間接的に脳幹網椂体にかかわりあって いるものと思われる. $\mathrm{SMV}_{3}$ は，何らかの抑制系の中枢 神経組織の関与が想定されるのではないかと考えられ る. Barbiturate の抑制的効果に対して, 逆に興奮した のはこの $\mathrm{SMV}_{3}$ であり, この点からも $\mathrm{SMV}_{3}$ の成分 の発現に関係ある神経組織は, 少くとも $\mathrm{SMV}_{1}$ および $\mathrm{SMV}_{2}$ の成分の発現に関係ある神経組織とは異る機能を 持つ神経組織であろうと推定される。

次に，TRH の場合であるが，本剂 $0.5 \sim 10 \mathrm{mg} / \mathrm{kg}$ の投 与量に抢いては, SMV の全成分に対して用量に比例し て強い抑制が認められた。ただし SNR に対しては0.5 〜 $1.0 \mathrm{mg} / \mathrm{kg}$ において軽度の抑制を示したが, それ以上で は殆ど影響を認めなかった. TRH は, 視床下部ホルモ ンの1つで, 神経薬理学的には neuromodulator とされ ている. 電気生理学的, 行動学的, 神経化学的研究に基 ゔいて, TRH の中枢作用の重要な作用点は, 脳幹網様 体, 視床下部, 視床, 側坐核, 線条体, 海馬, 大脳皮質 が挙げられている31-35)。安原ら36) 37) は, ウサギにつ いて電気生理学的検討を行い, 脳幹網様体刺激により大 脳皮質と海馬に認められる覚醒反応と前, 後肢に認めら れる誘発筋放電のいずれの閔値をも下降させる成績を 得, さらに脳幹網様体における単位放電の実験から, TRH は意識を覚醒させ, 運動機能に対しても促進的な 作用を有するとしている。これらの報告は，TRH が機 能的に興奮性に働く促進系 neuron を直接賦活するか,
あるいは抑制系の neuron を抑えることにより逆に興 擗をたかめるとしているが, 麻醉ラットの諸脳部位に TRH を電気泳動的に適用し, 単一 neuron の自発放電 などをみた報告によると，大脳皮質，楔状核，小脳皮 質, 視床下部, 中隔野においてTRH に応答する neuron は26〜70\%で，これらの大部分は抑制性に応答したと いう38)。 また最近, TRH の antinociceptiveな作用につ いての報告があり，マウスの脳室内に注入した TRHの antinociceptive activity は, 化学的刺激 (writhing test) や機械的刺激 (Haffner's test) による痛みに対して, morphine と同等以上であったとしている39) 40) 41) 42). 今回の実験における TRH に対する SMV および SNR の反応態度はすべて抑制的であったことは，TRH のむ う一面の作用の存在を示唆すると共に, SMV, SNR を 規制する何らかの中枢神経組織の介在も示唆するものと 思われる。

次に Cardiazol を負荷した場合, SMV では低濃度で やや興奮的化作用するが，10〜20 $\mathrm{mg} / \mathrm{kg}$ の高用量になる と強く抑制がかかることがわかった. SNR の場合は, SMV に比して早く抑制を受け， $5 \mathrm{mg} / \mathrm{kg}$ 以上で用量に比 例して抑制が認められた. Cardiazolの作用は，一次的に 中枢神経系に対するものであり, 脳脊咀連軸 cerebrospinal axis のすべてのレべルがこの薬物によって刺激される 29) 43). Lewin, Esplin の研究44) によれば, 本剂法興 奮性ならびに抑制 neuron の双方を刺激するという. 一 般に春髄の反射機能は著しく促進され，末梢の神経，筋 に対しても直接作用を示して興奮させるといわれている が43), 今回の実験では, SMV および SNR の波形か ら, SMV および SNR への作用には, 何らかの抑制系 の中枢神経組織が関与しているのではないかと考えられ る.

次に Amphetamine に対する反応態度であるが，第95 图にみる如く SMV の各成分のうち $\mathrm{SMV}_{1}$ に対しては 殆ど影響なく, $\mathrm{SMV}_{2}$ および $\mathrm{SMV}_{3}$ に対してはやや促 進的，SNR に対しては投与量を增すことによって抑制 が強くなる傾向がうかがわれた。このような SMV で は，わずかとはいえ促進， SNR では抑制が認められる 作用の傾向は，ある一面に打いて Cardiazol の作用と類 似点があるように思われる。

以上, SMV と SNR に対する薬物の作用を調べた実 験成績から, SMV の各 component の間にも, また SMV そSNR の間にも多少の相異は見られるものの, 根本的 な相違は見られなかった. そして SMV の機能的意義と しては，Barbiturate の適量投与下に抑制作用がみられ なかったことや，また CDP-choline, Cardiazol などの 
中枢興奮薬によっても強い興奮作用の見られなかったこ とから，また SNR との間隹薬物の作用に根本的な相異 の見られなかったことより, 意識との関係よりも疼痛と の関係を考えた方がよいのではないかと思われる.

\section{SMV と TMV}

既に述べた如く, MV 亿関する研究は光刺激, 音刺激 あるいは坐骨神経に対する電気刺激（侵害刺激）によ る MVで，未だ三叉神経に対して電気刺激を与えた場 合の MV を観察した報告はない。

本研究においては, 先に述べた SMV の導出の場合と 同一条件で，三叉神経の分枝である眼简上神経に電気刺 激を加えた場合の MV について検討した．私たちは三 叉神経の分枝に加えた刺激によって誘発された MV で あることから, trigeminal-evoked eyelid microvibration, すなわち TMV と命名した. TMV も， SMV の場合と 同様に 3 つの component よりなり, 第 1 成分の $\mathrm{TMV}_{1}$ は32 $\pm 10 \mathrm{msec}$, 第 2 成分の $\mathrm{TMV}_{2}$ は $53 \pm 11 \mathrm{msec}$ ， そ 乙て第 3 成分 $\mathrm{TMV}_{3}$ は $71 \pm 12 \mathrm{msec}$ にそれぞれの頂点 潜時を有していた。 これを SMV と対比すると，第 1 表 および第 5 表にみる如く，第 1 成分では $12 \mathrm{msec}$, 第 2 成 分では $10 \mathrm{msec}$ ，そして第 3 成分では $13 \mathrm{msec}$ だけ TMV の方が短い潜時を示した．これは坐骨神経と眼䆟上神経
とにおいて, 刺激から効果器までの距離が解剖学的に異 るためと考えるが，いずれにせよ microvibration として

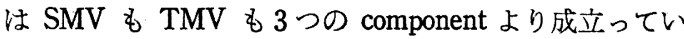
ることにはかわりはなく，また第 1 成分と第 2 成分，第 2 成分と第 3 成分の間隔についても, SMV の場合には

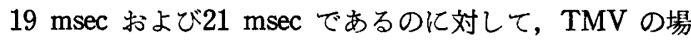

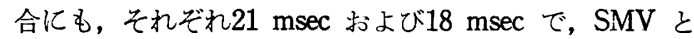
TMV は本質的に同じものと考允られる.

ついでこれら TMV および BR の各成分が，諸種中枢 作用薬によってどう影響するかを検討した．第96図注， その成績を第95图と同様にまとめたものである。まず Barbiturate 投与時であるが，TMV の各成分住対しては 一様に用量に比例して振巾の減少を認め, BR に対して も軽度の抑制を示した．しかし，SMV の第 2 ，第 3 成分およびSNR にみられた Barbiturate の比較的低用 量での興奮が, TMV ではみられなかった点は, TMV, BR と SMV， SNR とは様相を異にしていると考られ る.この作用の相異は, これらの現象に影響を及ぼす神 経組織の構成の違いによるものか, あるい法そのような 間接組織への作用の機序の違いによるものであろう.

CDP-choline 投与の場合においても，本剂の持つ脳幹 網様体賦活作用が, TMV の各成分に軽度ながら一様に
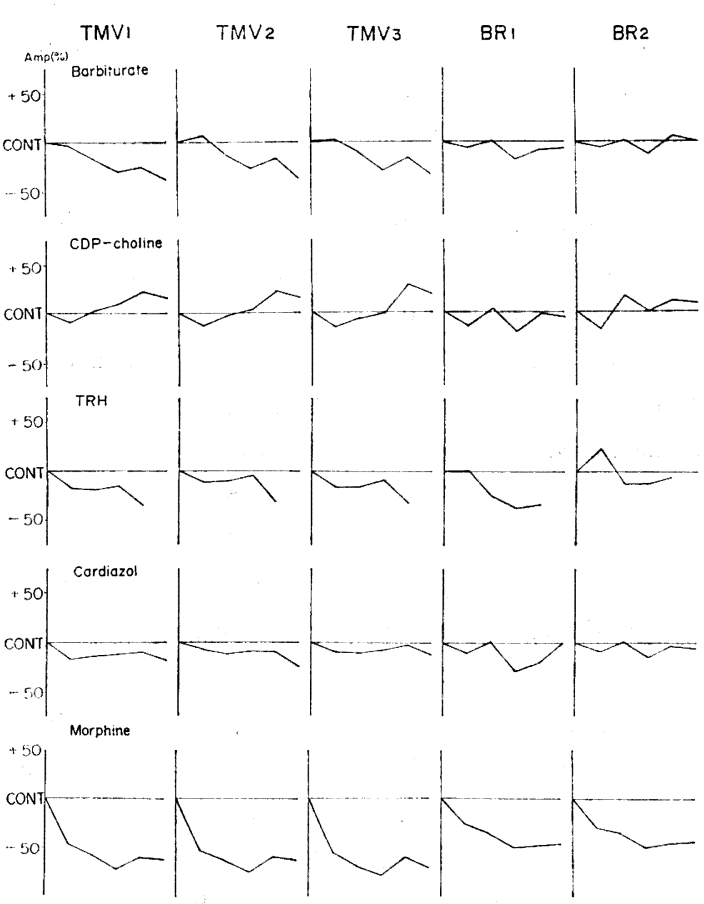

第96図 TMV および BR の各種中枢作用薬による影響の比較 
発現している様に思われる.しかしBR1にはむしろ, 若 干抑制傾向が同かれた，この TMV，BRの成績をSMV, $\mathrm{SNR}$ の成績と対比すると, $\mathrm{TMV}_{1}, \mathrm{TMV}_{2}, \mathrm{TMV}_{3}$, $\mathrm{BR}_{2}$ と $\mathrm{SMV}_{1}, \mathrm{SMV}_{2}, \mathrm{SNR}$ の成績の間には大きな相 違はみられなかった。 もっとも SMV の第 3 成分への抑 制的影響，および $\mathrm{BR}_{1}$ と $\mathrm{BR}_{2}$ の逆方向への作用がぞ んな意味と関係があるかということについては，これだ けの実績成績からは云々することはできないであろう。

ついで TRH 投与の影響は, TMV の 3 つの component に対して一様に抑制的に作用し，またとくに BR1 に対しても，TMV に対する以上の抑制が認められた.

これを SMV，SNR と対比してみてみると，いずれも 振巾の抑制を受ける点では共通しているが, SMV の各 成分の方が TMVに比してより強い抑制がみられるのに 対し, SNR と BR の比較で注，後者において強い抑制 がみられている，換言すれ泣，坐骨神経刺激の場合に は, TRH の抑制作用は SNR よりも SMV に対して強 く働き, 眼窝上神経刺激の場合には TMVょりも BR において強い抑制がかかっている点において両者の相違 が観察された。この相違は間接抑制組織ふらの各現象の 発現組織に対寸る抑制の程度の違いによるものである j.

次にCardiazol であるが，TMV およびBRに対してご く軽度の抑制勃果がみられた．この作用は，TMVに対 するより若干 BR に対して強く発現するように思われ た。これをSMVあるい注SNR に対する作用と対比する と, 眼窩上神経刺激時の TMV，BR に対しては殆ど促 進作用を示さないのに対して, SMV の各成分に対して 注, 少量に括いて Cardiazol の中枢興奮作用汸発現し, 投与量の増加につれ，抑制作用がみられるようになって いる. この作用態度注一見 Barbiturate のむのと似てい るけれども, Barbiturate の場合の少量促進作用は間接 抑制組織への抑制であるのに対して，Cardiazol の場合 は, 少量ではこの現象の発現と関係のある神経組織へ直 接作用し，大量投与下に間接抑制組織からの影響の加わ ることが考えられる，そしてTMV の場合には，Barbiturate の抑制作用は, TMV の発現組織の直接抑制作用 によるものであり，Cardiazol の抑制作用は間接抑制作 用が少量より示されたものと考えられる.

さて, 次に Morphine ${ }^{29)}$ であるが，一般にアヘン類は 脳および他組織における立体特異的ならびに飽和可能の 結合部位すなわち受容体と相互作用して agonist として 作用するとされ，これらの結合部位は中枢神経系㐾く 分布しているとされている，そしてこれらの結合部位に 対する親和性法，その鎮痛効果と相関する. Morphine
の鎮痛作用の特徵は，意識の消失なしにみられ，他の感 覚 (例えば触賞, 振動賞, 視覚, 聴覚) を鈍麻すること なく比較的選択的である。その作用点は脊髄の第 $I$, II 層, 脳幹三叉神経の脊蹃核, 大脳導水管周囲灰白質, 脊側縫線核などである。この Morphine の TMV に対 すると同様の抑制作用は立花 ${ }^{13)}$ により SMV でる観察 されており,このような Morphine の TMV に対する 作用態度からは, TMV む SMV と同様, 疼痛と関係の 深い反応であることが考えられるのである.

以上, TMV に対する薬物の反応態度は, SMV に対 する場合と若干の相違はあるが，これは恐らく眼窩上神 経と坐骨神経の解剖学的なしくみの相違によって，また 1 つには各薬物の濃度に対する反応のズレなどの複合さ れた結果によるものと考えられる。しかしながら基本的 には, SMV む TMV も同じ反応と考えられ, 中枢神経 内では一部同じ反射経路を通るものと考兄られる.

\section{TMV と BR}

光刺激などによって眼䀫部に誘発される微細振動を加 速度変化としてとらえた場合, これを MV と呼えでい るが，この反射性筋収縮を電位变化としてとらえる方法 は, 瞬目反射 (Blink reflex, BR) と称されている. 反 射性瞬目を眼輪筋の筋電図としてはじめて記録したのは Kugelberg45) であるが，その後, Kimura, Shahani, 平 岡ら 46-55) の多くの研究者によってその反射経路; 臨 床応用が検討されてきた．瞬目反射をひき起す方法は, Overend ${ }^{1)}$ ，Wartenberg4）らが報告した眉間や眼䈑外 側部の眼輪筋飞対する叨打による方法に始まって，角膜 刺激，光刺激，音刺激々種々試みられてきたが，なかで も三叉神経の第 1 分枝である眼窩上神経（supraorbital nerve）の電気刺激による blink reflex は, 最む広く研 究され臨床に応用されている方法である.

動物での瞬目反射関する研究には, Tokunaga ${ }^{53)}$, Lindquist $5^{54)}$, 平岡ら55) の報告がある. 今回私が行 った実験では，ウサギの右眼䈑上神経に電気刺激を加え た場合に右上眼䀫汇誘発される瞬目反射の記録である. ウサギの場合, 眼窩上神経の電気刺激により, 潜時の短 い成分と潜時の長い成分の 2 つが記録された。ここでは これをとれぞれ $\mathrm{BR}_{1}$ およこ $\mathrm{BR}_{\mathbf{2}}$ と呼ぶことにした． $\mathrm{BR}_{\mathbf{1}}$ は, 常に明瞭な棘波の形として発現し, 潜時は $3 \mathrm{msec}$ である. $\mathrm{BR}_{2}$ は $\mathrm{BR}_{1}$ に続いてゆるやかな山を形成し， 概祆 $10 \pm 1 \mathrm{msec}$ の潜時を持つ. BR1 は以前より推定さ れているように常に一定した単純波形を有し，潜時も短 く殆ど变化しないこと，また habituation がみられない などの理由で，電気刺激を直接経皮的にとらえているの ではないかとの疑問をいだかしめたが，薬物の投与き 
後に述べる中枢破壊の実験でみると, かなり变化に富 み，ときには $\mathrm{BR}_{2}$ の成分以上に変化する polysynaptic exteroceptive reflex であると考劣られる.

各種の中枢作用薬の投与を行うと, BR の各成分の変 化の方向性は, 概小 TMV の変化に平行するが, TMV に比して变化を強く受ける場合と弱い場合がある，とく に $\mathrm{BR}_{1}$ の成分においてみられ，Barbiturate と CDPcholine の場合には TMV に比して $\mathrm{BR}_{1}$ の変化は小さ い. この両薬㘊は, 脳幹網様体にとくに作用するもの で, 前者は抑制的に後者は促進的に作用するが，上述の 結果はTMVの方が BR1 に比して薬戍の影響を受け易い ことを意味している。これとは逆に，TRH と Cardiazol の場合には, TMV に比して $\mathrm{BR}_{1}$ の変化は大きい.

BR の成分間の比較では, CDP-choline と TRH の場合 において, $\mathrm{BR}_{1}$ と $\mathrm{BR}_{2}$ 間に幾分反応に差が認められた.
次に各種中枢破壊実験で得られた成績について考察す る. まず体性感覚入力を受ける外側部の VPL, VPM の 破壊によって $\mathrm{BR}_{1}, \mathrm{BR}_{2}$ の振巾は増大するものが多い. 一方, この際 TMV の各成分は, BR の変化とは逆に抑 制された.VPL および VPM からの主要な投射先は, 中心後回にある第一体性感覚野であって, 手, 足, 顔面 などから投射をうける neuron が多く，触・圧・振動な ぞ軽い機械的刺激により興奮する neuron が大部分であ るが, 最近, 第一体性感覚野の中に, あるいは VPLの 周辺や VPL と VL の境界部に限局して, 痛覚の識別 的な側面にかかわる侵害受容性 neuron が存在すること がわかってきた56).

一方, 瞬目反射における $\mathrm{BR}_{1}$ および $\mathrm{BR}_{2}$ の役割につ いて, $\mathrm{BR}_{1}$ は 3 neuron 反射, すなわち三叉神経一三叉 神経知覚核一顔面神経の反射で脳幹網様体と関係の市
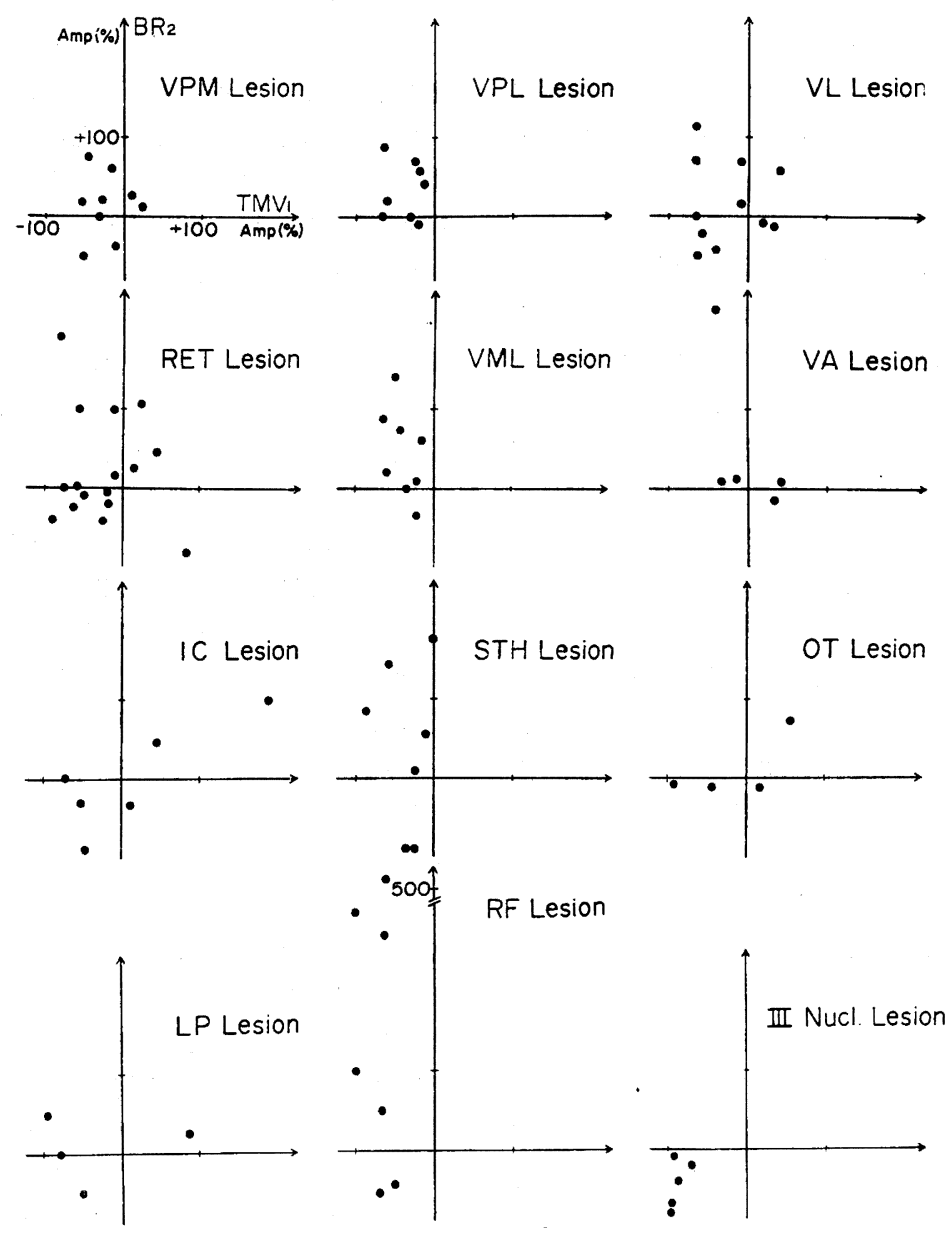

第97図 中枢破壊による TMVおよび BR の变化の相関 
ることが示唆されており, $\mathrm{BR}_{2}$ については, 三叉神経 と両側顔面神経との間の polysynaptic response である とされているが, $\mathrm{BR}_{1}$ と同様脳幹網様体とのかかわりの ほかに，より上位の中枢の関与も推定されている ${ }^{57)}$.

これらの事実から, VPL, VPM の破壊によって, TMV の発現と関係のある侵害受容性 neuron の活動が抑えら れ，その結果として BR は促進されたものと考えられ る.これと同じ反応態度, すなわち BR 捉進, TMV は抑制のパターンを示したのは，LP，VML， RF， RET そして STH であった（第 $6 ， 7$ 表).

第97図は, TMV と BR の反応態度を座標軸を利用し て表現し，両者の関係をわかりやすくしたものである. すなわち，縦軸に BR（ここでは $\mathrm{BR}_{2}$ を代表として採 用）を，横軸に TMV（ここでは第 1 成分を採用）を 取って，各個体ごとの反応椂式をプロットした．これに より左上段の相は，TMV 抑制，BR促進，左下段の相 は TMV， BR共に抑制を，また右上段の相にプロット が多ければ TMV， BR 共に促進を表わすことになる.

第 6，7表および第97図からわかるように，その他 VL, VA， IC，OT は必ずしも一定の傾向は示さなかっ た。また $\mathrm{CM}$ の破壊は 1例とはいえ，TMV は抑制， BRは促進という作用パターンがみられた.

以上の実験成績から TMV は VPL, VPM, VML, LP, RET, STH などの視床核を経由した後, 脳幹網様 体，動眼神経核と興奮の伝わることが考えられるのであ る. そして VA, VL, OT, IC などは TMV の伝導路 に対して促進および抑制の神経細胞あるいは神経線維の 存在することが考えられる. VPL, VPM, 脸幹網様体, 動眼神経核などの成績は，立花 ${ }^{13)} の \mathrm{SMV}$ の破壊実験 の成績と同様である. 一方, BR は VPL, VPM, VML, LP， RET，STH などの核より抑制的な影響を受けてい ることが考えられるのである。

TMV と BR は，ともに眼窩上神経刺激によって誘発 された上眼䀫の反射性筋収縮でありながら，決して同じ 反応を示すとは限らず，これまでの基礎的，臨床的検討 からすると, BR は脳幹網様体の機能を反映していると されているが，脳幹網様体の破壊により TMV は抑制さ れたのに BR では促進的影響のみられたことから， BR の発現には, 脳幹網様体以外の何らかの系により強く支 配されていると考えられる．そしてTMV は，今回の実 験成績から SMV と本質的には同一のものであることが 考えられるのである.

以上, 本研究は $\mathrm{TMV}$ と $\mathrm{BR}$ が受容器と, そして一 部効果器も同一のものであると考元られる現象でありな がら，その中枢経路あるいは薬物に対する感受性瀷る
ことを明らかにしたものであるが，TMV の機能的意義 としては, 破壊実験の成績や Morphine の作用態度から SMV と同様, 疼痛と関係の深いことが考えられるので ある。

\section{総括}

坐骨神経刺激による眼䀫部のSMV と侵害反射(SNR). および三叉神経刺激による上眼䀫 TMV と瞬目反射 (BR）の機能的意義を明らかにするために，無麻酔ウサ ギを用い実験を行い，以下の如き成績が得られた。

1. 坐骨神経刺激により, ウサギの上眼䀫に誘発され るSMV は，3つの component から構成され，その頂点 潜時はそれぞれ44士10 $\mathrm{msec}, 63 \pm 11 \mathrm{msec}$ およ゙ $84 \pm$ $7 \mathrm{msec}$ であった.

2. 同時に測定した前脛骨筋における侵害反射性笳放 電 (SNR) の頂点潜時は, $13 \pm 5 \mathrm{msec}$ であった.

3. 坐骨神経に対する電気刺激を 1 秒 1 回, 50 回平均 加算を 10 分間隔で 5 回反復した場合の habituation を検 討した結果, SMV，SNR 共その頂点潜時には影響を与 えないが，振巾は経時的に減衰の傾向が認められた。

4. 坐骨神経の刺激部位の左右差による右上眼䀫 SMV の頂点潜時は統計的に有意差を認めなかった。

5. SMV に対する諸種中枢作用薬の影響をみた実験 では, Barbiturate 注比較的少量で促進的に，さらに大 量では抑制的に作用し，TRH は用量依存的に抑制作用 がみられた。CDP-choline は軽度の促進作用を示した が, $\mathrm{SMV}_{3}$ は抑制された. Cardiazol では, Barbiturate と同様，少量で促進，大量で抑制の作用がみられたが， Amphetamine では，概して著明な変化を認めなかった。

6. SNRに対する薬物の影響は, Barbiturate と CDPcholine が促進的に作用し, Cardiazol および Amphetamine は抑制的であった.

7. 薬物に対する SMV と SNR の反応態度は同傾向 であったが，一部拮抗関係もみられた。

8. 眼窩上神経刺激により眼䀫部に誘発される TMV は3つの component より構成され，その頂点潜時の平

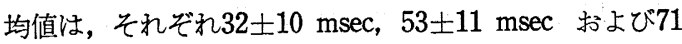
土12 msec であった。

9. TMVと同時に記録した同眼䀫部の瞬目反射 (BR) は2つの component, すなわち $\mathrm{BR}_{1}$ および $\mathrm{BR}_{2}$ よ り構成され，これらの頂点潜時の平均值は，それぞれ $3 \pm 0 \mathrm{msec}, 10 \pm 1 \mathrm{msec}$ であった.

10. TMV に対する諸種中枢作用薬の影響をみた実験 では, Barbiturate, TRH, Cardiazol, Morphine は, 各 component に対し抑制的に作用し，Morphine の影響が 
最も強くあらわれた。

CDP-choline では TMV の各 component に対しやや 促進的に作用した.

11. BR に対する薬物の作用は, Barbiturate, CDPcholine, TRH, Cardiazol および Morphine 共に抑制的 に作用した.

12. 薬物に対する $\mathrm{TMV}$ と BR の反応態度は, 概して 同方向であった。

13. 知覚中継核群 (VPL, VPM) の破壊によって, TMV の各 component の振巾は減少し，BR は 增大し た.

14. 視床非特殊核に属する RET, CM, VML，LP の破填でも, TMV の各 component は減少し, BR は 増大した. VA, VL の破壊では TMV, BR とも, 各 component の振巾は増大するものと, 隇少するものがあ った.

15. 中脳網様体 (RF) の破壊の場合は, TMV は減少 し, BR は增大した。
16. 動眼神経核の破壊では, TMV は完全に抑制され BR の抑制は軽度であった。

17. STH の破壊では，TMV の第 1 成分は振巾が減少 し, BR では大部分が増大した。

18. その他 IC, OT の破壊では一定の傾向を示さな かった.

以上の実験成績より,TMV は SMV と同様の中枢神 経組織を経由して現われる反応であり，BR とはその発 現機序の異なる現象であることを明らかにした。

本論文要旨の一部は, 日本生理学会第65回近畿生理学 談話会および第69回近畿生理学談話会において発表し た.

稿を終るに瀶み，ご孤切なる御指導，御校閲をいただ きました恩師安原基弘教授に心からお礼申しあげます。 また終始適切な御助言, 御指導を下さいました内藤博江 助教授に深く感謝致しますと共に，種々御協力下さいま した教室員各位に謝意を表します。

\section{考文献}

1) Overend, W. : Preliminary note on a new cranial reflex, Lancet 1, 619 (March 6), 1896.

2) Levinsohn, G. : Über Lidreflexe. vgl. Gräfes Archiv. f. Ophthalmol. 50, Heft 3, 381 423, 1904.

3) Levinsohn, G. : Der optische Blinzelreflex.

Zeitschr. f. d. ges. Neur. u. Psych., 20, 377 $\sim 385,1913$.

4) Wartenberg, R. : The examination of reflexA simplification.（佐野圭司訳 : 反射の検査, 医 学書院, 東京, 1953.)

5) Rohracher, H. : Schwingungen im menschlichen organismus. Anz. d. phil. -hist. Klasse d. Oster. Akad. d. Wiss., 18, 230 245, 1946.

6）尾崎俊行, 藤原克三, 伊藤 久: 閃光刺激倸よる 誘発眼䀫微小振動について. 日本生理誌, 28 , 241 242, 1966.

7）西浦公章：Microvibration の発現機序に関する 電気生理学的研究. 関西医大誌, 32, 586 623, 1980.

8）服部裕子：光眼輪笳反射の late component の発 現機序に関する実験的研究. 関西医大誌, 34, 377 426, 1982.
9）山田あいこ：聴覚誘発眼輪筋反射に関する電気生 理学的研究 第 1 編一ウサギにおける神経薬理学 的検討一. 関西医大誌, 35, 575〜 593, 1983.

10）山田あいこ：聴覚誘発眼輪筋反射関する電気生 理学的研究 第 2 編一中枢神経系の破壊および切 断実験一. 関西医大誌, 36, 160 171， 1984.

11）山本由美：Microvibration に及ほす皮質下核の影 響に関する電気生理学的研究(第 1 報)一刺激およ び破壞実験一. 関西医大誌，39，45～76，1987.

12）山本由美：Microvibration に及ほす皮質下核の影 響侸関する電気生理学的研究 (第 2 報) 一誘発筋 放電との比較研究一. 関西医大誌, 39, 77〜 93, 1987.

13）立花和男：坐骨神経刺激による誘発電位に関す る神経薬理学的研究. 関西医大誌, 39，1 44, 1987.

14）䏚波・筋電図用眖の手引（9）: 臨床脳波， 28, $78,1986$.

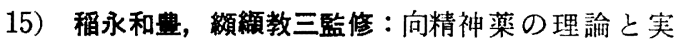
際, 医蕋薬出版, 東京, 1973.

16）稲永和豊：Microvibration の基礎とその臨床への 応用. 耳鼻, 14 (補冊 1)，21 36, 1968.

17）尾崎俊行, 工藤洋子 : 閃光刺激により眼䀫から導 出される電位変動の生理的性質. 臨床脳波, 18 , 
$769 \sim 772,1976$.

18）寺本成美：誘発眼䀫 MV 反応による脳幹部障害 の検討. 臨床脳波，21，600～609， 1979.

19）丸尾孝一郎 : 光眼輪筋反射の神経薬理学的研究. 関西医大誌, 27, 439〜472, 1975.

20）大友敏行 : 光眼輪筋反射の発生機序に関する実験 的研究. 関西医大誌, 31，258～295， 1979.

21）安原昭博, 山田あいこ, 内藤博江, 安原基弘：光 刺激により眼䀫上より記録される長潜時誘発電位 に関する研究．脳波と筋電図，12，153～158， 1984.

22）安原昭博, 山田あいこ, 安原基弘, 松村忠樹: 小 児の光眼輪筋反射について，脳研究会々誌， 8 , $44 \sim 45,1982$.

23）安原昭博, 山田あいこ, 松村忠樹, 安原基弘 : 新 生児の photo-evoked eyelid microvibration一基礎 的検討一. 臨床脸波, 24, 257 262, 1982.

24）安原昭博, 山田あいこ, 杉本健郎, 松村忠樹, 安 原基弘：新生児の頭垍内出血と新生児仮死におけ る光眼輪筋反射. 脳神経, 34, 725〜 732, 1982.

25）安原昭博，堀あいこ，松村忠樹：小児の意職障害 における photo-evoked eyelid microvibration. 臨 床脳波, 27, 110 114, 1985.

26）問田直幹，内䓢耕二，伊藤正男，富田忠雄編集 : 新生理学, 上巻 動物的機能編, 第 5 版, 医学 書院, 東京, 1982.

27）岛村宗夫, 中村隆一編 : Analysis of Motor Function in Human-Methods and clinical applications, 医歯薬出版, 東京, 1980.

28）安原基弘：網様体と誘発電位. 生体の科学, 6 , 59〜70, 1954.

29) Goodman Gilman, A. , Goodman, L. S. , Rall, T. W. and Murad, F. : Goodman \& Gilman's The Pharmacological Basis of Therapeutics. 7th edition, Macmillan Pub. Company, New York, 1985.

30）啮谷健編 : 新薬理学入門. 南山堂, 東尔, 1981.

31) Nagawa, Y., Miyamoto, M., Nagai, Y. and Narumi, S. : Mechanism of antipentobarbital action of thyrotropin-releasing hormone (TRH). J. Pharmaco. Dyn. 3, S-10, 1980.

32）佐治美昭, 神子田武, 名川雄児：Thyrotropin Releasing Hormone (TRH) のネコにおける脸波, 交感神経および呼吸賦活作用の作用点. 武田研究 所報, 36, 39 45, 1977.
33）土居孝行，佐治美昭，名川雄児：視床破壊ネコに おける Thyrotropin-releasing hormone (TRH) の覚醒効果. 薬理と治療, 6, 3229 3236, 1978.

34) Tonoue, T. : Effect of thyrotropin-releasing hormone on heart rate and visual evoked potentials in rats. Endocrinol. Japan, 24, 271 276, 1977.

35）福田尚久, 佐治美昭, 名川雄児 : 脳幹圧迫による ネコの行動および脸波変化ならびにそれに及ぼす Thyrotropin-releasing hormone (TRH) の影響. 日薬理誌, 75, 321 331, 1979.

36) Yasuhara, M. and Naito, H. : Effects of TRH-T and DN-1417 on the central nervous system : An electrophysiological study of arousal reaction and evoked muscular discharges. Intern. J. Neuroscience, 21, 197 223, 1983.

37) Yasuhara, M., Naito, H., Takemura, K. , Sawada, M. , Takeda, N. and Yamamoto, T. : Effects of TRH-T and DN-1417 on Photopalpebral Reflex and Microvibration. J. Kansai Med. Univ. 36, S-17〜S-29, 1984.

38）名川雄児 : Thyrotropin-Releasing Hormone（TR H）の中枢神経薬理. 武田研究所報， 39，151～ 191, 1980.

39) Boschi, G., Desiles, M. , Reny, V., Rips, R. and Wriggleworth, S. : Antinociceptive properties of thyrotropin releasing hormone in mice : Comparison with morphine. $\mathrm{Br}$. J. Pharmacol. , 79, 85〜92, 1983.

40) Rips, R., Reny, V. and Desiles, M. : Suppression of naloxone, hyperalgesia by TRH. IRCS Med. Sci., 11, 110 111, 1983.

41) Webster, V.A. D., Griffiths, E. C. and Slator, P. : Antinociceptive effects of thyrotropinreleasing hormone and its analogues in periaqueductal grey region. Neurosci. Lett., 42, 67〜 70, 1983.

42) Ramaswamy, S. , Chandra, D. and Bapna, J.S. : Interaction between prolactin and thyrotrophin releasing hormone with respect to analgesia. IRCS Med. Sci., 12, 859, 1984.

43) 中井健伍, 上条一也, 高折修二編: 薬理学, 第 2 版 理工学社, 東京, 1984.

44) Lewin, J. and Esplin, D. W. : Analysis of the spinal excitatory action of pentylenetetrazol. J. 
Pharmac. exp. Ther., 132, 245 250, 1961.

45) Kugelberg, E. : Facial reflexes. Brain, 75, 385 396, 1952.

46) Kimura, J. : Alteration of the orbicularis oculi reflex by pontine lesions. - Study in multiple sclerosis. Arch. Neurol., 22, 156 161, 1970.

47) Kimura, J., Powers, J. M. and Van Allen, M.W. : Reflex response of orbicularis oculi muscle to supraorbital nerve stimulation. - Study in normal subjects and in peripheral facial paresis. Arch. Neurol., 21, 193 199, 1969.

48) Kimura, J., Rodnitzky, R. L. and Van Allen, M. W. : Electrodiagnostic study of trigeminal nerve. -Orbicularis oculi reflex and masseter reflex in trigeminal neuralgia, paratrigeminal syndrome and other lesions of the trigeminal nerve. Neurology, 20, 574 583, 1970.

49) Shahani, B. : Effects of sleep on human reflexes with a double component. J. Neurol. Neurosurg. Psychiat., 31, 574 579, 1968.

50) Shahani, B. : The human blink reflex. J. Neurol. Neurosurg. Psychiat., 33, 792 800, 1970.

51) Shahani, B. T. and Young, R. R. : Blink reflexes in orbicularis oculi, in "New Developments in Electromyography and Clinical Neurophysiology" Vol. 3 (Desmedt, J.E. ed.), pp. 641 648, Karger, Basel, 1973.

52) Lyon, L. W. and Van Allen, M. W. : Orbicularis oculi reflex. Studies in internuclear opthaImoplegia and pseudointernuclear ophthalmo plegia. Arch. Ophthal. ,; 87, 148 154, 1972.

53) Tokunaga, A., Oka, M., Murao, T., Yokoi, H., Okumura, T., Hirata, T., Miyashita, Y. and Yoshitatsu, S. : An experimental study on facial reflex by evoked electromyography. Med. J. Osaka Univ., 9, 397 411, 1958.

54) Lindquist, C. and Mårtensson, A. : Mechanisms involved in the cat's blink reflex. Acta physiol. scand., 80, 149 159, 1970.

55）平岡満里 : ネコの角膜刺激による反射性瞬目の 神経機構について. 日眼会誌, 80, 168〜176, 1976.

56）岩村吉晃：体性感覚之視床. Clin. Neurosci., 3, 612 616, 1985.

57）河村弘康：瞬目反射の基礎と臨床応用. 脳神経外 科, 11, 123 139, 1983. 
（欧 文 抄 録）

\title{
A Neuropharmacological Study on the Evoked Muscular Discharge due to Stimulation of the Sciatic and Trigeminal Nerves
}

\author{
Kyoichi Katoh \\ Department of Physiology, Kansai Medical University \\ Moriguchi, Osaka, Japan \\ (Supervised by Prof. M. Yasuhara)
}

A neuropharmacological and electrophysiological study was carried out in order to investigate the mechanism of the sciatic and trigeminal evoked eyelid microvibration (SMV and TMV), and blink reflex (BR) in rabbits.

The results obtained were as follows ;

1. The response of SMV, induced in the upper eyelid by sciatic nerve stimulation, was composed of three components, which had peak latencies of $44 \pm 10,63 \pm 11$, and $84 \pm 7$ msec, respectively.

2. The peak latency of the nociceptive reflex (SNR), recorded simultaneously in the anterior tibial muscle, was $13 \pm 5 \mathrm{msec}$.

3. The latency time of SMV and SNR was not changed statistically by the repeated electric stimulation of the sciatic nerve, but the amplitude indicated habituation.

4. There was no difference in the latency time of SMV, induced in the left upper eyelid, between the response to the sciatic stimulation of the left site and that of right site.

5. Each SMV component was increased in amplitude by the low dose of barbiturate and decreased by the high dose. It was also suppressed, dose-dependently, by TRH. CDPcholine suppressed the $\mathrm{SMV}_{1}$ and $\mathrm{SMV}_{2}$ components, but increased that of $\mathrm{SMV}_{3}$.

Cardiazol increased SMV component in a low dose, but decreased it in a high dose. The SMV was little influenced by amphetamine.

6. The amplitude of SNR increased with barbiturate and CDP-choline, but decreased with TRH, cardiazol and amphetamine.

7. SMV and SNR responded to most of the agents in the same way, but an antagonistic relationship was observed, in part, in the response between SMV and SNR.

8. Three components were also recorded in the TMV, their peak latencics being $32 \pm 10$, $53 \pm 11$ and $71 \pm 12 \mathrm{msec}$, respectively. 
9. The BR recorded simultaneously consisted of two components ; the peak latencies of which were 3 and $10 \pm 1 \mathrm{msec}$, respectively.

10. Barbiturate, TRH, cardiazol and morphine, administered intravenously, suppressed each TMV component, and the effect of morphine was the strongest. CDP-choline increased each TMV component.

11. BR was suppressed in amplitude by all agents.

12. The TMV and BR responses to these agents showed almost the same behavior.

13. A lesion in the sensory relay nucleus, such as posterolateral ventral nucleus (VPL) and posteromedial ventral nucleus (VPM), increased each TMV component, while it decreased that of BR.

14. Impairments of the nucleus reticularis (RET), the nucleus centrum medianum (CM), the nucleus ventralis medialis pars lateralis (VML) and the nucleus lateralis posterior (LP), which belong to the non-specific projection nuclei, also decreased each TMV component, and increased that of BR. There was no definite trend with TMV and BR respone when the nucleus ventralis anterior (VA) and the nucleus ventralis lateralis (VL) were impaired.

15. The amplitude of each TMV component decreased with a lesion in the brain stem reticular formation ( $R F)$, while that of $B R$ increased.

16. Lesion in the oculomotor nuclei (III-nucl.) suppressed each TMV component completely, but that of BR, moderately.

17. Impairment of the subthalamus (STH) decreased the amplitude of the first component of TMV and that of BR.

18. Impairment of the capsula interna (IC) and optic tract (OT) did not show any definite response in TMV and BR.

These results indicate that the TMV response appears to be the same as that of SMV in mediating, in part, the same relay nucleus or synapse of the central nervous system, and that it differs from $\mathrm{BR}$ in the mechanism of response. 